\title{
Taxonomia de Fanniidae (Diptera) do sul do Brasil - II: Novas espécies e chave de identificação de Fannia Robineau-Desvoidy
}

\author{
Lisiane Dilli Wendt ${ }^{1} \&$ Claudio José Barros de Carvalho ${ }^{1}$
}

'Departamento de Zoologia, Universidade Federal do Paraná, Caixa Postal 19020, 81531-980 Curitiba-PR, Brasil. lisidilli@yahoo.com.br; cjbcarva@ufpr.br

\begin{abstract}
Taxonomy of Fanniidae (Diptera) of southern Brazil - II: New species and key to identification of Fannia Robineau-Desvoidy. Fannia are found in all biogeographic regions, except in the poles. This present contribution concerns to 22 species found in southern Brazil including three new species: Fannia opsia sp. nov. from Ponta Grossa (Paraná), Fannia pulvinilenis sp nov. from Pelotas (Rio Grande do Sul) and Fannia xanthothrichia sp. nov. from São José dos Pinhais (Paraná). Fannia carvalhoi Couri, 2005 is recorded for first time in Brazil. The female of Fannia admirabilis Albuquerque, 1958 is described for the first time. A key for identification of male and female to species in southern Brazil is presented. Ilustrations of main diagnostic characters including male and female terminalia are also included.
\end{abstract}

KEYWORDS. Morphology; Muscoidea; Neotropical region.

RESUMO. Taxonomia de Fanniidae (Diptera) do sul do Brasil - II: Novas espécies e chave de identificação de Fannia Robineau-Desvoidy. Fannia é encontrada em todas as regiões biogeográficas, exceto nos pólos. A presente contribuição refere-se às 22 espécies encontradas na região Sul do Brasil incluindo três novas espécies: Fannia opsia sp. nov. de Ponta Grossa (Paraná), Fannia pulvinilenis sp. nov. de Pelotas (Rio Grande do Sul) e Fannia xanthothrichia sp. nov. de São José dos Pinhais (Paraná). Fannia carvalhoi Couri, 2005 é registrada pela primeira vez para o Brasil. É descrita pela primeira vez a fêmea de Fannia admirabilis Albuquerque, 1958. Além disto, são apresentadas chaves de identificação para macho e fêmea para as espécies da região. Ilustrações dos principais caracteres diagnósticos e das terminálias masculina e feminina são incluídas.

PALAVRAS-CHAVE. Morfologia; Muscoidea; Região Neotropical.

Fannia Robineau-Desvoidy é o maior gênero de Fanniidae com aproximadamente 260 espécies e ocorre em todas as regiões biogeográficas, exceto nos pólos. Os adultos de Fannia são encontrados em áreas de florestas sobre arbustos ou em flores. As larvas são saprófagas, podendo se desenvolver em diversos substratos, como matéria orgânica animal ou vegetal, fungos e fezes (Malloch 1934; Chillcott 1961; Holloway 1984; Rozkosný et al. 1997).

Fannia possui importância econômica, pois diversas espécies possuem hábito sinantrópico (Almeida et al. 1985; Bruno et al. 1992, 1993; Campos \& Barros 1995; Carvalho et al. 2002; Labud et al. 2003). Algumas espécies são vetoras de ovos da mosca do berne-Dermatobia hominis Linnaeus Jr, 1781 (Oestridae) (Ribeiro et al. 1985; Guimarães \& Papavero 1999; Brum et al. 1996; Gomes et al. 2002; Espíndola \& Couri 2004), ou ainda, estão relacionadas à decomposição de cadáveres de animais, podendo assim, ter importância na entomologia forense (Monteiro-Filho \& Penereiro 1987; Moura et al. 1997; Carvalho et al. 2000; Marchiori et al. 2000; Amendt et al. 2004).

Para a região Neotropical, o conhecimento taxonômico de Fannia é relativamente amplo. Os últimos trabalhos em taxonomia com chaves de identificação para as espécies de Fannia para a região foram: Albuquerque et al. (1981) para as espécies de Fannia neotropicais; Pont \& Carvalho (1994) para as espécies de Fannia do grupo anthracina; Carvalho et al.
(2002) para as espécies de Fanniidae associadas ao ambiente humano; Couri (2005a) para espécies de Fannia do subgrupo pusio e Dominguez (2007) para as espécies da Argentina e Chile. Ainda, recentemente, sete novas espécies foram descritas para a Região Neotropical (Couri 2004, 2005b; Couri \& Winagraski 2005; Dominguez 2007).

Para o Brasil as maiores contribuições taxonômicas do gênero foram os trabalhos de Dalcy de Oliveira Albuquerque, com descrição de 12 espécies (Albuquerque 1954a, b, c, 1956, 1957, 1958, 1980; Albuquerque et al. 1981) e diversas redescrições e notas de espécies já conhecidas (Albuquerque 1945a, b, 1946, 1953, 1954b, 1957; Albuquerque et al. 1981). E recentemente novas espécies foram descritas para o Brasil (Couri \& Araújo 1989; Couri \& Pamplona 1990; Carvalho 1991; Carvalho \& Couri 1993; Araújo \& Couri 1996; Couri 2004; Couri \& Winagraski 2005).

Diversos grupos de espécies de Fannia foram propostos de acordo, principalmente, com caracteres da terminália de macho e de fêmea. Chillcott (1961) indicou 11 grupos e diversos subgrupos para as espécies da região Neártica. Para a região Neotropical, Albuquerque et al. (1981) reconheceram oito grupos de espécies. Contudo, estes trabalhos não indicam a monofilia e a relação filogenética destes grupos de espécies.

Entretanto, apesar do grande conhecimento taxonômico de Fannia para a região Neotropical, diversas áreas dentro da região ainda foram pouco estudadas. Para a região sul do Brasil, 
as informações a respeito da família são fragmentadas e incipientes, fazendo-se necessários maiores estudos sobre a fauna de Fanniidae nesta região.

O trabalho de Wendt \& Carvalho (2007) compreendeu as espécies de Euryomma Stein da região sul do Brasil. O presente trabalho é o segundo sobre Fanniidae para a região, e inclui as espécies de Fannia. São apresentadas descrições de novas espécies e redescrições de espécies já conhecidas, com ilustrações de caracteres importantes para o reconhecimento, bem como chaves de identificação para macho e fêmea.

\section{MATERIALEMÉTODOS}

Material e métodos seguem Wendt \& Carvalho (2007) quanto: às coleções as quais forneceram material para a observação, à preparação das terminálias masculina e feminina, à terminologia adotada e às siglas no material examinado. Entretanto, apresentaram algumas diferenças, listadas abaixo.

Foram incluídos além de exemplares com ocorrência nos estados do Sul do Brasil (Rio Grande do Sul, Santa Catarina e Paraná) exemplares disponíveis de localidades adjacentes, como Paraguai e os Estados do Mato Grosso do Sul e São Paulo, devido a sua grande proximidade geográfica com os estados da região do estudo. Para as espécies, as quais não foram encontrados exemplares macho e/ou fêmea nas coleções examinadas, foram utilizadas informações disponíveis na literatura para a redescrição e para elaboração da chave de identificação. Para espécies não encontradas nas coleções, todavia, com ocorrência na Região Sul, segundo a literatura, utilizaram-se espécimes de outros estados brasileiros (Mato Grosso, Minas Gerais e Rio de Janeiro).

A identificação do material foi feita através de chaves de identificação (Seago 1954; Albuquerque et al. 1981; Pont \& Carvalho 1994; Carvalho et al. 2002; Couri 2005a) e de descrições originais e/ou redescrições. Quando possível, os espécimes foram comparados com o material-tipo.

As descrições e redescrições das espécies foram seguidas em ordem alfabética. Assim, não foram ordenadas e reunidas de acordo com os grupos de espécies propostos por Chillcott (1961) e Albuquerque et al. (1981), entretanto, foram feitas discussões sobre a alocação das espécies nestes grupos.

A chave de identificação para machos permite a identificação de todas as espécies de Fannia do Sul do Brasil. Entretanto, para fêmeas do subgrupo pusio (de acordo com Albuquerque et al. 1981), a chave não permite a identificação a nível específico.

A diagnose foi baseada nos caracteres exclusivos de cada espécie, ou no conjunto de caracteres não exclusivos que permitisse o fácil reconhecimento da espécie. As redescrições foram baseadas nos caracteres mais conspícuos de cada espécie, assim, não foram descritas as mesmas estruturas para todas as espécies.

As principais estruturas diagnósticas utilizadas estão representadas e indicadas nas figuras 1-7.

As fotografias coloridas (Figs. 8-20) foram adquiridas através do programa Auto-Montage Pro (Syncroscopy) e câmara Leica DFC 500 acoplada ao esterioscópio Leica MZ16.

\section{RESULTADOSEDISCUSSÃO}

Na região Sul do Brasil foram encontradas 22 espécies de Fannia, incluindo três novas, e 13 novos registros para a região (Tabela I).

Tabela I. Número de espécies conhecidas até este trabalho, segundo [1] Albuquerque et al. (1981); [2] Carvalho et al. (2002); [3] Carvalho et al. (2003); [4] Couri (2004); [5] Couri (2005b); [6] Couri \& Winagraski [2005]; [7] Dominguez (2007), e o número atual de espécies conhecidas de Fannia Robineau-Desvoidy, 1830:

\begin{tabular}{lcc}
\hline \multirow{2}{*}{ Áreas } & \multicolumn{2}{c}{ Número de espécies } \\
\cline { 2 - 3 } & Conhecidas & Atual \\
\hline Região Neotropical [1, 3, 4, 5, 6, 7] & 73 & 76 \\
América do Sul [1, 3, 4, 5, 6, 7] & 62 & 65 \\
Brasil [1, 2, 3, 5] & 40 & 44 \\
Sul do Brasil [2] & 12 & 22 \\
Paraná [2] & 12 & 20 \\
Santa Catarina [1] & 02 & 11 \\
Rio Grande do Sul [2] & 06 & 11
\end{tabular}

\section{Fannia Robineau-Desvoidy}

Fannia Robineau-Desvoidy, 1830: 567. Espécie-tipo: Fannia saltatrix Robineau-Desvoidy = Musca scalaris (Fabricius, 1794).

Diagnose: cerda orbital inferior geralmente ausente no macho; primeira cerda dorsocentral pré-sutural desenvolvida, mais que a metade do comprimento da segunda; asa com a veia anal 2 fortemente curvada, a extensão imaginária das duas veias anais encontra-se muito antes da margem da asa; machos com abdome alargado antes da margem posterior do tergito II e processo baciliforme geralmente presente; fêmea com tergito II distintamente mais longo que o tergito III (Chillcott 1961).

Distribuição: o maior número de espécies é registrado para a região holártica. Para Rozkosný et al. (1997) esta diversidade sugere uma boa evidência de sua origem em áreas florestais das zonas temperadas. Na América do Norte ocorrem aproximadamente 100 espécies (Stone et al. 1965). Para a Europa são registradas 79 espécies (Rozkosný et al. 1997). Na região Oriental ocorrem 28 espécies (Pont 1977a); Austrália e Oceania, 12 (Pont 1977b, 1989) e na região Afrotropical, 10 espécies (Crosskey 1980). Na região Neotropical são conhecidas atualmente 76 espécies (Carvalho et al. 2003; Couri 2004, 2005b; Couri \& Winagraski 2005; Dominguez 2007) já somadas às três novas espécies incluídas neste trabalho (Tabela I).

Comentários: O gênero possui uma grande diversidade morfológica. A identificação dos machos geralmente é facilitada pela presença de caracteres sexuais secundários, entretanto, em algumas espécies, as fêmeas permaneceram relativamente primitivas (Chillcott 1961), principalmente, quanto aos caracteres das pernas médias e posteriores e de terminália. As fêmeas de certos grupos, essencialmente, dos gupos scalaris 
(subgrupo pusio) e heydenii (de acordo com Albuquerque et al. 1981), são muito similares entre si e a sua identificação é bastante problemática, muitas vezes não sendo possível determinar a espécie.

Chave de identificação para machos de Fannia da Região Sul do Brasil

(Machos de Fannia xanthocera e Fannia xanthothrichia sp. nov. desconhecidos)

1. Comprimento total do corpo de 2,5 a 3,5 mm. Parafaciália com uma série de pequenos cílios (Figs. 24, 30, 31, 33, 34). Placa fronto-orbital glabra e negra brilhante. Coloração geral negra. Abdome trimaculado (Fig. 116). Processo baciliforme ausente (Figs. 155, 163, 164, 166, 167) 2 (subgrupo pusio)

Comprimento total do corpo maior que $3,5 \mathrm{~mm}$. Parafaciália nua. Placa fronto-orbital geralmente coberta com forte polinosidade cinzenta. Coloração geral variada. Abdome de coloração variada. Processo baciliforme geralmente presente (Figs. 151-154, 156-162, 168, 169), exceto Fannia scalaris (Fig. 165) 6

2. Fêmur posterior na face ventral reto, sem protuberância pré-apical (Figs. 85, 102); face anteroventral com uma série de cerdas curtas (Fig. 85)

Fannia trimaculata (Stein)

Fêmur posterior na face ventral curvo, com uma forte (Figs. 73, 84, 92, 101) ou fraca (Figs. 81, 82, 98, 99) protuberância pré-apical; face anteroventral sem série de cerdas (Figs. 73, 82, 84) ... 3

3. Tíbia posterior na face ventral com uma série de cerdas longas e finas (Fig. 81) ..... Fannia pusio (Wiedemann) Tíbia posterior na face ventral sem cerdas longas e finas, com no máximo três cerdas curtas e fortes .... 4

4. Fêmur posterior na face ventral curvo com fraca protuberância (Figs. 82, 99), não visível anteriormente; face anterovetral com três a quatro cerdas de ápice reto e espaçadas entre si, a partir do terço apical (Fig. 82) ...................................... Fannia sabrosky Seago

Fêmur posterior na face ventral com forte protubência préapical (Fig. 82, 84, 99, 101), visível anteriormente; face anteroventral com conjunto de cerdas curtas e cerradas (Fig. 84) ou longas e curvas (Fig. 82) préapical

5. Fêmur posterior na face anteroventral com três a quatro cerdas pré-apicais longas e de ápice em gancho (Fig. 73), distintamente maiores que as correspondentes posteroventrais (Fig. 92) ...... Fannia femoralis (Stein)

Fêmur porterior na face anteroventral com um conjunto de cerdas curtas e cerradas (Fig. 84), de mesmo tamanho que as correspondentes posteroventrais (Fig. 101) Fannia snyderi Seago
6. Coxa posterior na face posterior nua (Figs. 88 e 89) ........ 7

Coxa posterior na face posterior ciliada (Figs. 90, 91, 93$97,100,103,104)$

7. Coloração geral amarelada, exceto, tarsômeros castanhoescuros. Cerdas frontais em número de cinco a seis pares, na metade inferior da fronte (Fig. 21). Fêmur posterior na face ventral curvo pré-apicalmente e no terço apical, nas faces ventral, anteroventral (Fig. 69) e posteroventral (Fig. 88) com cerdas longas e de ápice curvo ................... Fannia admirabilis Albuquerque

Coloração geral negra, com reflexos azulados. Cerdas frontais em número de 16 a 19 pares, distribuídas em todo o comprimento da fronte (Fig. 22). Fêmur posterior nas faces ventral e posteroventral com uma forte protuberância pré-apical onde se inserem um forte conjunto de cerdas longas e fortes (Fig. 89)

Fannia albitarsis Stein

8. Fêmur posterior nas faces ventral e posteroventral com um forte conjunto de cerdas que formam um tufo (Figs. 91, 94, 97, 103, 104)

Fêmur posterior nas faces ventral e/ou posteroventral nua (Figs. 90, 96, 100) ou com um fraco conjunto de cerdas pré-apicalmente (Figs. 93, 95) .. 14

9. Escuto castanho sem listra 10

Escuto castanho ou acinzentado com listras 12

10. Tíbia anterior na face anterodorsal com uma cerda submediana. Tíbia posterior na face ventral com uma cerda pré-apical forte, curva e longa (Figs. 72, 91). Basitarso posterior dilatado e na face posterior com uma reentrância formando uma "dobra" apicalmente (Fig. 91). Abdome castanho-escuro com manchas amarelas nos tergitos III-IV (Fig. 108). Esternito I nu. Processo baciliforme alongado (Figs. 154, 173) ...

Fannia carvalhoi Couri

Tíbia anterior na face anterodorsal sem cerda submediana. Tíbia posterior na face ventral sem cerda pré-apical (Figs.74, 79). Basitarso posterior não dilatado e face posterior sem reentrância. Abdome castanhoacinzentado com tergitos I-IV amarelo-translúcidos lateralmente (Figs. 114, 118). Estenito I ciliado. Processo baciliforme cuneiforme (Figs. 161, 168) ... 11

11. Cerdas frontais em número de 10 a 12 pares (Fig. 35). Escuto e escutelo castanhos

Fannia tumidifemur Stein

Cerdas frontais em número de 11 a 19 pares (Fig. 29).

Escuto castanho-escuro até o segundo par de cerdas dorsocentrais pós-suturais e castanho-claro desta região até o ápice do escutelo (Fig. 55)

Fannia penicillaris (Stein)

12. Asa hialina com as veias transversais fortemente orladas 
de castanho (Fig. 20). Esternito I nu.

. Fannia punctipennis Albuquerque

Asa amarelada, sem manchas. Esternito I ciliado 13

13. Base do escutelo castanha e ápice acinzentado (Fig. 54). Caliptras branco-amareladas com bordas amareladas a acastanhadas. Halter esbranquiçado.

Fannia heydenii (Wiedemann)

Escutelo cinza com três manchas acastanhadas distintas na base (Fig.56). Calíptras brancas. Halter amarelado Fannia yenhedi Albuquerque

14. Olhos esparsamente ciliados. Tórax inteiramente castanhoescuro a negro. Asa acasanhada (Figs. 16-18) ....... 15

Olhos nus. Tórax acinzentado a castanho-claro, com ou sem listras dorsalmente. Asa amarelada 17

15. Halter amarelo. Um par de cerdas pré-escutelares desenvolvidas. Tíbia anterior nas faces anterodorsal e posterior com uma cerda submediana inseridas praticamente na mesma altura. Abdome negro com manchas amareladas nos tergitos I-III (Fig. 111) ..... Fannia itatiaiensis Albuquerque

Halter castanho. Dois pares de cerdas pré-escutelares desenvolvidas. Tíbia anterior nas faces anterodorsal e posterior sem cerdas submedianas. Abdome inteiramente castanho escuro a negro (Figs. 112, 113)

16. Tíbia média na face posterior com duas cerdas medianas. Fêmur posterior na face posterior sem cerdas diferenciadas (Fig. 96). Processo baciliforme afixado à placa cercal, em forma de gancho (Fig. 159)

Fannia obscurinervis (Stein)

Tíbia média na face posterior com 1 cerda no terço apical. Fêmur posterior na face posterior com cerdas finas e mais longas que as cerdas de revestimento (Fig. 11). Processo baciliforme fusionado ao epândrio, rugoso com densos espinhos em sua superfície (Fig. 160) ... Fannia opsia sp. nov.

17. Tíbia posterior na face anterior com uma série de cerdas (Figs. 71, 83) 18 Tíbia posterior na face anterior sem cerdas (Figs. 74, 80)...19

18. Cerda orbital superior ausente (Fig. 32). Coxa média com três fortes cerdas em forma de aguilhões (Fig. 66). Tíbia média na face ventral com um tubérculo no terço apical (Fig. 67). Abdome alongado com uma listra mediana castanha e lateralmente com densa polinosidade cinzenta (Fig. 117)

Fannia scalaris (Fabricius)

Cerda orbital superior presente (Fig. 3). Coxa média sem cerdas em forma de aguilhões. Tíbia média sem tubérculo. Abdome acinzentado com os tergitos I-IV amarelo-translúcidos (Fig. 107)

Fannia canicularis (Linnaeus)
19. Escuto pré-suturalmente castanho-escuro com duas listras acizentadas medianas e pós-suturalmente castanho-claro sem listras (Fig. 53). Tarsômeros castanho-escuros, sem dilatação. Fêmur posterior na face posteroventral com um fraco conjunto pré-apical de cerdas finas e de ápice curvo (Fig. 93). Esternito I nu. Fannia flavicincta (Stein)

Escuto castanho-claro com reflexos dourados, podendo ou não apresentar listras não muito nítidas até a base do escutelo (Fig. 13). Tarsômeros com reflexos dourados e levemente dilatados dorsoventralmente (Fig. 15). Fêmur posterior na face posteroventral nu pré-apicalmente. Esternito I densamente ciliado ......... . Fannia pulvinilenis sp. nov.

Chave de identificação para fêmeas de Fannia da Região Sul do Brasil

(Fêmeas de Fannia opsia sp. nov., Fannia pulvinilenis sp. nov. desconhecidas)

1. Coxa posterior na face posterior nua ..................................... 2

Coxa posterior na face posterior ciliada ............................. 4

2. Escapo, pedicelo, flagelômero e palpo amarelos. Abdome acinzentado ou castanho com manchas ..................... 3

Escapo, pedicelo, flagelômeros e palpos castanhos escuros. Abdome inteiramente negro-azulado (Fig. 121) ..................................... Fannia albitarsis Stein

3. Cerdas frontais em número de dois pares intercalados por diversos cílios (Fig. 37). Tórax amarelo. Halter castanho. Tíbia média na face posterior com duas cerdas medianas e na face ventral sem cerdas. Abdome com tergito I-II e base lateral do tergito III amarelos translúcidos (Fig. 120). Três espermatecas (Fig. 242)

Fannia admirabilis Albuquerque

Cerdas frontais em número de oito a nove pares de diferentes tamanhos sem cílios intercalando-os (Fig. 49). Tórax acinzentado, dorsalmente com cinco listras castanho-claras (Fig. 61). Halter esbranquiçado. Tíbia média na face posterior com uma cerda submediana e na face ventral com uma cerda no terço apical. Abdome com a base dos tergitos I-III amarelados e ápice dos tergitos I-V castanho-claro, tergitos IV-V com manchas acizentadas esparsas na base (Fig. 129). Duas espermatecas (Fig. 252).

Fannia xanthocera Albuquerque

4. Tíbia média na face posterior com uma cerda mediana ... 5 Tíbia média na face posterior com duas cerdas mediana ... 11

5. Espécies de comprimento geral reduzido (até $3,5 \mathrm{~mm}$ ). Parafaciália com uma série de pequenos cílios (Figs. 45, 47, 48). Placa fronto-orbital glabra e negra brilhante. Duas cerdas pré-alares. Abdome inteiramente negro metálico subgrupo 
pusio incluindo: Fannia femoralis (Stein), Fannia pusio (Wiedemann), Fannia sabroskyi Seago, Fannia snyderi Seago e Fannia trimaculata (Stein)

Espécies de comprimento geral a partir de $4 \mathrm{~mm}$. Parafaciália sem pequenos cílios. Placa fronto-orbital coberta com forte polinosidade geralmente prateada. Uma cerda pré-alar (exceto Fannia itatiaiensis Albuquerque). Abdome castanho ou acinzentado com ou sem manchas castanho-claras, podendo apresentar tergitos amarelados ... 6

6. Tíbia posterior na face posteroventral com uma série de cerdas. ... 7

Tíbia posterior sem tais cerdas

7. Placa fronto-orbital com uma a duas séries de cílios fortes distribuídos irregularmente (Fig. 46). Tórax homogeneamente cinza-azulado. Abdome inteiramente cinza (Fig. 128). Três espermateca diferentes entre si (Fig. 261)

Fannia scalaris (Fabricius)

Placa fronto-orbital com uma série de cílios fracos (Fig. 39). Tórax cinza, dorsalmente com três listras castanhas estreitas (Fig. 57). Abdome cinza com os tergitos I-II amarelo-translúcidos (Fig. 122). Duas espermatecas globosas (Fig. 244)

Fannia canicularis (Linnaeus)

8. Escuto com três listras que estendem-se até o escutelo (Figs. 59, 60, 62) 9

Escuto inteiramente castanho ..... Fannia carvalhoi Couri

9. Tíbia média face ventral com uma ou duas cerdas submediana 10

Tíbia média face ventral sem as tais cerdas

.. Fannia heydenii (Wiedemann)

10. Asa acastanhada com as veias transversais, principalmente a r-m, fortemente orladas de castanho escuro (Fig. 20) ... Fannia punctipennis Albuquerque Asa amarelada sem manchas .

Fannia yenhedi Albuquerque

11. Olhos esparsamente ciliados. Escuto sem listras. Fêmur anterior na face posteroventral com uma série de cerdas, a partir do terço basal. Tíbia anterior na face anterodorsal com uma cerda submediana. Tíbia posterior na face anteroventral com uma a três cerdas

Olhos nus. Escuto com duas listras medianas (Fig. 58). Fêmur anterior na face posteroventral com uma série curta de cerdas a partir do terço apical. Tíbia anterior na face anterodorsal sem cerda submediana Tíbia posterior na face anteroventral com cinco a sete cerdas Fannia flavicincta (Stein)
12. Tórax amarelo a castanho claro (Fig. 14). Asa amarelada (Fig. 14). Coxa, trocanter e fêmur castanho-claros (Fig. 14). Abdome com tergitos I-II amarelo-translúcidos (Figs. 14, 130) ............. Fannia xanthothrichia sp. n. Tórax castanho-escuro. Asas castanhas com a margem superior castanho-escura (Figs. 16, 17). Pernas inteiramente castanho-escuras. Abdome inteiramente castanho-escuro a negro . .13

13. Duas pré-alares. Um par de cerdas pré-escutelares desenvolvidas. Caliptras inteiramente esbranquiçadas. Halter amarelo. Tíbia anterior face posterior com uma cerda submediana ... Fannia itatiaiensis Albuquerque Uma pré-alar. Dois pares de cerdas pré-escutelares desenvolvidas. Caliptras amareladas a castanhas, podendo apresentar os bordos amarelados ou castanhos. Halter castanho. Tíbia anterior face posterior sem cerda submediana .

Fannia obscurinervis (Stein)

\section{Fannia admirabilis Albuquerque, 1958}

(Figs. 21, 37, 69, 88, 105, 120, 132, 151, 170, 189, 208, 227, 242)

Diagnose: olhos esparsamente ciliados; antena e tórax amarelados; coxas, trocânteres e fêmures amarelados a castanho-claros; coxa posterior na face posterior nua. Macho com os olhos fortemente aproximados, com os omatídeos desenvolvidos, cerca de 1/3 do tamanho dos ocelos.

Redescrição: Macho: comprimento total 5-5,2 mm (N=4); asa 4,8-4,9 $\mathrm{mm}(\mathrm{N}=4)$. Holóptico. Olhos fortemente aproximados, com cílios curtos e esparsos. Omatídeos desenvolvidos, com cerca da terça parte do tamanho dos ocelos. Triângulo ocelar proeminente com ocelos desenvolvidos (Fig. 21) e geralmente amarelados. Na fronte, entre o triângulo ocelar e as cerdas frontais, há de cinco a seis pares de cílios fracos. Cerdas frontais em número de cinco a seis pares, limitados ao terço anterior das órbitas (Fig. 21). Placa fronto-orbital, vita frontal, parafaciália, gena, e face castanho-escuras aveludadas. Escapo, pedicelo e flagelômero amarelos. Arista plumosa (Fig. 21), castanha com a base amarelada. Palpo amarelo e clavado, com o ápice medindo cerca de 1,5 a largura da base. Labro castanho. Premento amarelado. Escuto amarelo a castanho-claro. Pleuras amarelas com o anepímero apresentando uma mancha castanho-escura. Duas cerdas pré-alares indistintas dos cílios de fundo. Caliptras castanho-claras. Base do halter esbranquiçada e ápice castanho-claro. Asa amarelada. Coxas, trocânteres e fêmures amarelados a castanho-claros. Tíbias e tarsos castanhoescuros. Fêmur anterior na face posteroventral com uma série completa de cerdas longas e espaçadas entre si. Tíbia média na face posterior com duas cerdas submedianas. Coxa posterior na face posterior nua. Fêmur posterior faces ventral (Figs. 69, 88) e posteroventral (Fig. 88) com ligeira protuberância préapical, nas quais inserem-se cerdas longas e de ápice curvo, sendo mais densas na face ventral. Abdome com tergitos I-III 

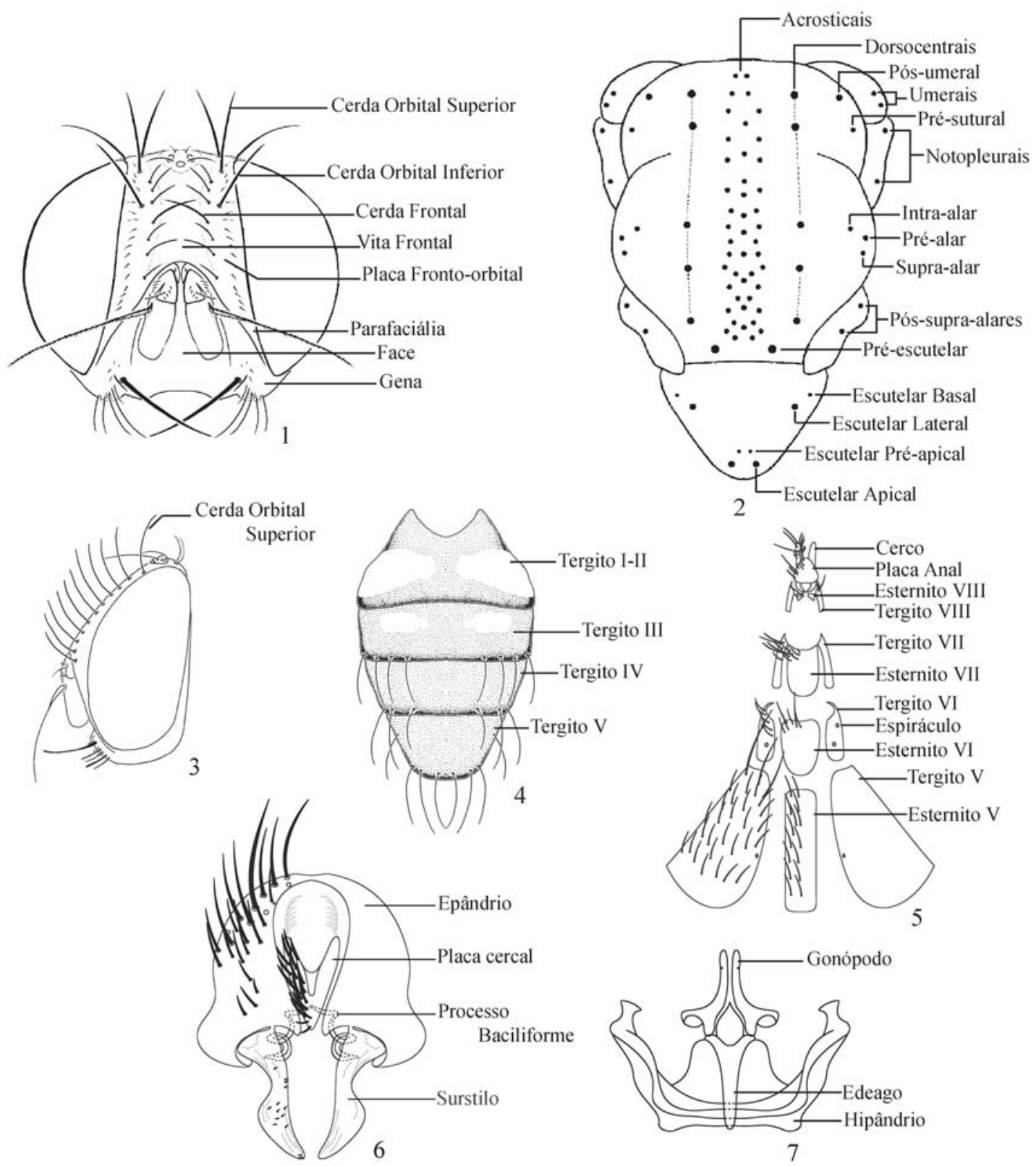

Figs. 1-7. Caracteres morfológicos: 1, Cabeça, fêmea, vista frontal, Fannia canicularis; 2, Tórax, vista dorsal, quetotaxia; 3, Cabeça, macho, vista lateral, F. canicularis; 4, Abdome, vista dorsal, F. itatiaiensis; 5, Terminália, fêmea, F. flavicincta; 6, Terminália, macho, vista dorsal, $F$. albitarsis; 7, Processo fálico, vista dorsal, F. admirabilis.

amarelo-translúcidos lateralmente e tergitos IV-V castanhoclaros (Fig. 105). Esternito I ciliado. Esternito V como na figura 132. Terminália (Figs. 151, 170): epândrio mais largo que longo, coberto por cerdas de diferentes tamanhos; surstilos estreitamente fusionados ao epândrio, longos e afilados apicalmente. Processo baciliforme bifurcado (Fig. 151). Hipândrio e estruturas associadas (Figs. 189 e 208).

Descrição: Fêmea: Comprimento total 5,0-5,1 mm (N=5); asa 4,7-4,8 mm ( $\mathrm{N}=5)$. Dicóptica.

Cabeça (Fig. 37): Espaço interocular 0,45 a 0,48 vezes o tamanho da cabeça ao nível do ocelo anterior. Omatídeos pouco desenvolvidos, menor que a quinta parte do tamanho dos ocelos. Cerdas frontais em número de dois pares fortes e cinco a sete pares de cerdas fracas. Triângulo ocelar negro com um par de cerdas e dois pares de cílios, todos anterovertidos. Ocelos pouco desenvolvidos (Fig. 37), esbranquiçados a amarelados. Vita frontal, parafaciália, gena e face castanhas. Placa fronto-orbital com uma a duas séries desordenadas de cílios. Cerda orbital inferior divergente e cerda orbital superior voltada para a porção posterior da cabeça. Flagelômero mede cerca de 2,8 vezes o comprimento do pedicelo.

Tórax: Cerdas acrosticais em três séries desordenadas e ao nível do segundo par de cerdas dorsocentrais pós-suturais 
com quatro a cinco séries de cerdas desordenadas. Cerdas dorsocentrais 2:3. Duas cerdas umerais, a interna menor. Uma cerda pós-umeral e uma pré-sutural maior. Duas cerdas notopleurais. Uma a duas cerdas pré-alares pequenas, indistintas dos cílios de fundo. Uma cerda supra-alar, duas intra-alares e duas pós-supra-alares. Escutelo castanho. Um par de cerdas escutelares basais e um par de cerdas escutelares apicais desenvolvidas; um par de laterais e um par de pré-apicais menores. Caliptras amareladas a castanho-claras, podendo apresentar borda castanho-escura. Caliptra inferior cerca de 0,5 vezes o tamanho da superior. Halter com a base amarelada e ápice castanho.

Pernas: Pulvilos pequenos e esbranquiçados. Tíbia anterior na face dorsal com uma cerda pré-apical forte; faces ventral e posterior com uma cerda apical forte; face anterodorsal com uma cerda fraca submediana. Fêmur médio na face anterodorsal com uma série completa de cerdas; face posterior com quatro cerdas fortes e curvas a partir do terço apical. Tíbia média na face ventral sem pubescência; face anterodorsal com uma cerda apical e uma no terço apical; faces ventral e posteroventral com uma cerda apical, sendo a primeira mais forte. Fêmur posterior na face anteroventral no terço apical e pré-apical com uma cerda longa, face anterodorsal com uma série de cerdas, nas quais a partir do terço apical dirigem-se para a face dorsal. Tíbia posterior face dorsal na porção média e pré-apical com uma cerda; face anterodorsal no terço apical com uma cerda; face anteroventral com duas a três cerdas medianas e uma cerda apical forte.

Abdome: Tergitos I-II e base do tergito III amarelos, ápice do tergito III e tergitos IV-V castanho-escuros (Fig. 120). Terminália (Fig. 227): cerco pouco mais longo que a placa anal, coberto uniformemente por cerdas de tamanhos semelhantes; placa anal mais longa que larga, coberta por cílios; esternito VIII reduzido em duas placas anteriores membranosas e duas placas posteriores ciliadas, totalmente esclerotinizadas; esternitos VI e VII mais largos que longos com duas séries horizontais de cerdas na porção apical. Três espermatecas estriadas (Fig. 242).

Comentários: Albuquerque (1958) descreveu F. admirabilis baseado apenas em um macho. No material examinado do DZUP foram encontrados exemplares fêmeas, tornando possível sua descrição.

F. admirabilis pertence ao grupo admirabilis, representado apenas por esta espécie (Albuquerque et al. 1981). Entretanto, devido à fêmea ser desconhecida, os autores não caracterizaram o grupo. Mas de acordo com a descrição da fêmea de $F$. admirabilis no pesente trabalho, o grupo pode ser caracterizado por apresentar a placa anal mais longa que larga; esternito VIII reduzido em duas placas anteriores membranosas e duas placas posteriores ciliadas, totalmente esclerotinizadas; esternitos VI e VII mais largos que longos e três espermatecas.

Primeiro registro para o Paraná.

Biologia: Não há registro sobre a biologia de F. admirabilis na literatura. Entretanto, nos dados de etiqueta do material examinado constam que os exemplares desta espécie foram coletados em armadilhas Malaise e luminosa.

Material-tipo examinado: Holótipo macho (MNRJ): 'Itatiaia, L. Azul, E. do Rio\ Trav., Barth, Albuquerquel Barros col. 26-IX-1954'.

Material adicional examinado: Brasil. Paraná: Curitiba, xii.1985, S. L. Loroca (1 fêmea, DZUP); Ponta Grossa, Reserva IAPAR, Br 376, 8.xii.1986, Levantamento Entomológico PROFAUPAR (1 fêmea, DZUP); São José dos Pinhais, Serra do Mar, Br 277, Km 54, 3.iii.1985, C.I.I.F. (1 fêmea, DZUP); mesmo loca, 31.x.1986, Levantamento Entomológico PROFAUPAR (1 fêmea, DZUP); idem, 4.xi.1986, idem (1 macho, DZUP); idem, 30.xi.1986, idem (1 macho, 2 fêmeas, DZUP); idem, 1.xii.1986, idem (1 macho, 1 fêmea, DZUP); idem, 2.xii.1986, idem (1 macho, DZUP).

Distribuição geográfica: Brasil: Rio de Janeiro e Paraná.

Fannia albitarsis Stein, 1911

(Figs. 22, 38, 51, 63, 64, 70, 89, 106, 121, 133, 152, 171, 190, $209,228,243)$

Diagnose: Macho apresenta os tarsos anteriores brancoamarelados, fortemente achatados dorsoventralmente e dilatados lateralmente e basitarso anterior na face posterior com forte espinho foliforme apical. Fêmea apresenta de dez a 12 pares de cerdas frontais, halter amarelado e abdome inteiramente negro azulado.

Redescrição: Macho: comprimento total 5,0-6,0 mm (N=7); asa 4,0-5,5 mm (N=7). Holóptico. Olhos ciliados. Cerdas frontais em número de 16 a 19 pares de diferentes tamanhos (Fig. 22). Vita frontal negra. Placa fronto-orbital, parafaciália, gena e face coberta com densa polinosidade prateada. Escapo, pedicelo e arista castanhos-escuros. Flagelômero negro com polinosidade cinzenta. Arista com cílios bastante curtos. Palpo castanho-escuro e clavado, com o ápice medindo cerca de 1,5 a largura da base. Tórax negro com reflexo azulado, dorsalmente com três listras cinza-azuladas não muito nítidas, as quais coincidem com as acrosticais e dorsocentrais (Fig. 51). Uma pré-alar pequena e área pré-alar nua. Caliptras esbranquiçadas. Halter e asa amarelados. Tarsos anteriores branco-amarelados e achatados dorsoventralmente e dilatados lateralmente (Fig. 63). Basitarso anterior na face posterior com um forte espinho foliforme apical (Fig. 63). Tíbia média na face posterior com uma cerda mediana. Tarsômero médio basal na face ventral com uma "crista" seguida de uma cerda curva e forte apical (Fig. 64). Coxa posterior na face posterior nua. Fêmur posterior nas faces ventral (Figs. 70, 89) e posteroventral (Fig. 89) com uma forte protuberância pré-apical, na qual se insere um forte tufo de cerdas longas e de ápice curvo. Abdome negro com forte polinosidade cinzenta (Fig. 106). Esternito I ciliado. Esternito V (Fig. 133). Terminália (Figs. 152, 171): epândrio mais longo que largo, em forma de "sino", mais alargado na margem posterior, coberto por cerdas de diferentes tamanhos, sendo mais denso na porção basal; surstilo estreitamente fusionado ao epândrio e fracamente clavado; placa cercal afilada apicalmente coberta por densas cerdas curtas; processo baciliforme espiralado (Fig 152). Hipândrio e estruturas associadas (Figs. 190, 209). 

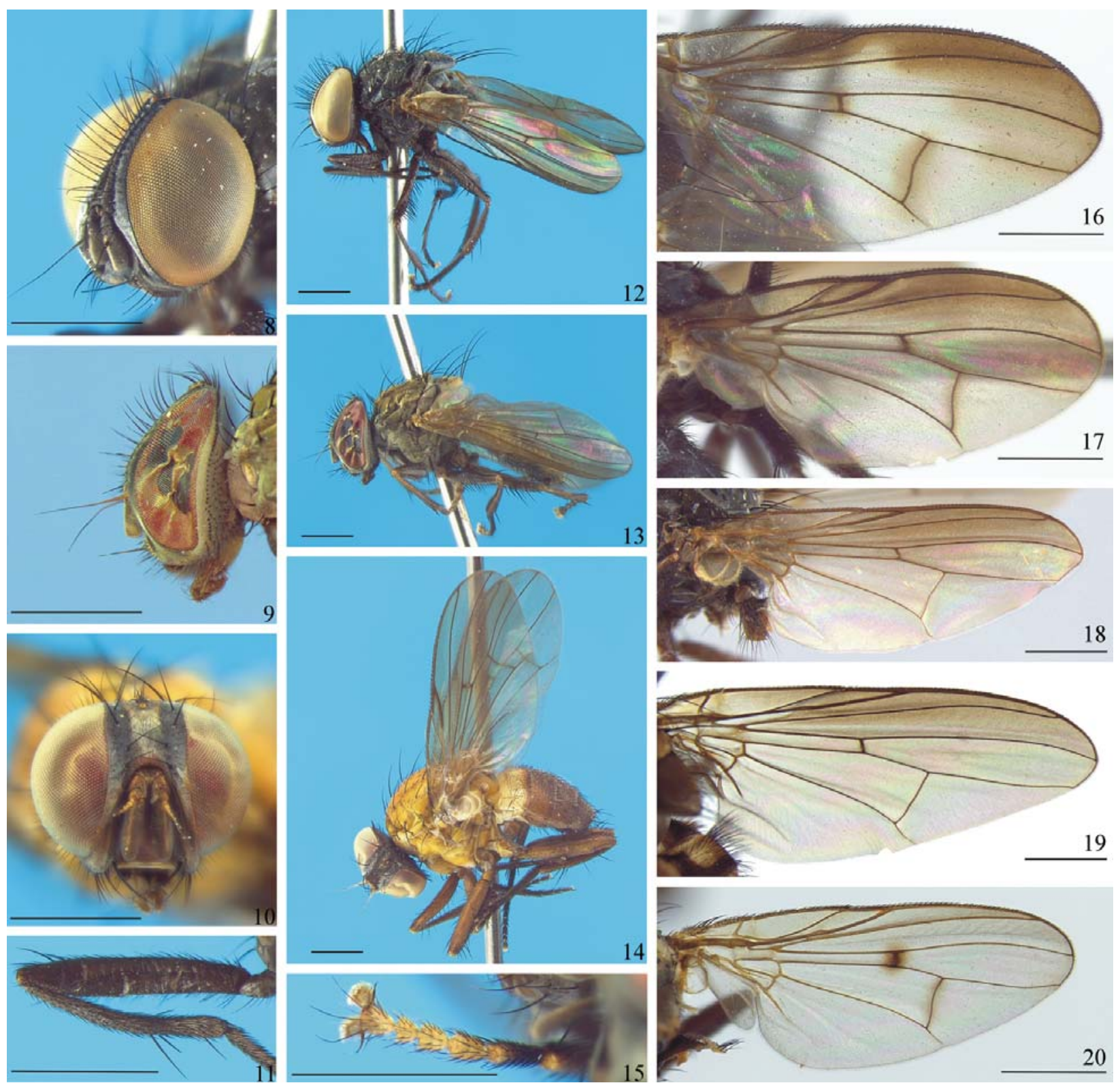

19

4

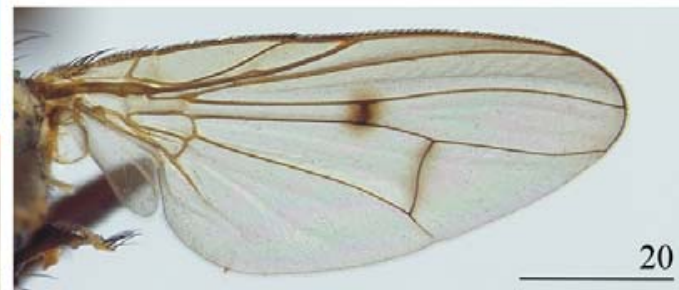

Figs. 8-20. Fannia: 8-10: Cabeça: 8, Macho, vista latero-frontal, F. opsia sp nov.; 9, Macho, vista lateral, F. pulvinilenis sp. nov.; 10, Fêmea, vista frontal, F. xanthothrichia sp. nov.; 11, Macho, perna posterior, vista posterior, F. opsia sp nov.; 12-14: Adulto, vista lateral: 12, F. opsia sp. nov.; 13, F. pulvinilenis sp. nov.; 14, F. xanthothrichia sp. nov.; 15, Macho, tarsômeros anteriores, F. pulvinilenis sp. nov.; 16-20: Asa: 16, F. itatiaiensis; 17, F. obscurinervis; 18, F. opsia sp. nov.; 19, F. penicillaris; 20, F. punctipennis. Escala: $1 \mathrm{~mm}$.

Fêmea semelhante ao macho, exceto: comprimento total 4,0-6,0 mm ( $\mathrm{N}=10)$; asa 3,5-5,0 mm ( $\mathrm{N}=10)$. Dicóptica. Cerdas frontais em número de 10 a 12 pares de diferentes tamanhos (Fig. 38). Cerda orbital inferior divergente (Fig. 38). Tarsos anteriores inteiramente negros e não dilatados. Fêmur posterior nas faces ventral e posteroventral sem protuberância pré-apical e sem tufo de cerdas. Abdome inteiramente negro-azulado (Fig. 12). Terminália (Fig. 228): cercos pouco mais longos que a placa anal, cobertos por cerdas, sendo as apicais mais longas que as demais; placa anal mais longa que larga e uniformemente coberta por cerdas; esternito VIII reduzidos em duas placas, apresentando quatro a seis cerdas de diferentes tamanhos; esternito VII quase tão longo quanto largo e esternito VI mais largo que longo, ambos com uma série horizontal de cerdas na porção apical. Duas espermatecas estriadas (Fig. 243).

Comentários: F. albitarsis pertence ao grupo anthracina (Albuquerque et al. 1981; Pont \& Carvalho 1994). Este grupo é composto por seis espécies, sendo caracterizado, principalmente, por apresentar: olho ciliado, coxa posterior na face posterior nua, abdome negro, tarsômeros anteriores esbranquiçados e freqüentemente modificados, tarsômero basal médio na face ventral com uma crista seguida por uma cerda curta e forte, fêmur posterior na face ventral com forte 
protuberância apical onde se inserem um forte conjunto de cerdas (Pont \& Carvalho 1994).

Primeiro registro para São Paulo, Paraná e Santa Catarina.

Biologia: Na Argentina esta espécie possui hábito sinantrópico, estando associada à produção avícola (Perotti 1998), contudo, para o Brasil não há trabalhos referentes a coletas de F. albitarsis em ambientes urbanos. Entretanto, os dados de etiqueta dos espécimes observados demonstram que esta espécie pode ser coletada em locais urbanizados, podendo assim, estar associada este tipo de ambiente.

Material-tipo (não examinado). Lectótipo macho e paralectótipos macho e fêmea, depositados no Staatliches Museum für Tierkunde (SMTD), na Alemanha, e paralectótipos de macho e fêmea depositados no Museum für Naturkunde der Humboldt-Universität, na Alemanha (Carvalho et al. 2003).

Material examinado: Brasil. São Paulo: Iporanga, Fazenda Intervales, Gruta Colorida, 04.ii.1984, E. Trajano col. (1 macho, DZUP). Paraná: Estrada do Cerne, Km11, 13.viii.1975, A. Imbiriba col. (13 fêmeas, DZUP); idem, 20.viii.1975, idem (8 fêmeas, DZUP); idem, 3.ix.1975, idem (5 fêmeas, DZUP); idem, 10.ix.1975, idem (10 fêmeas, DZUP); idem, 17.ix.1975, idem (2 fêmeas, DZUP); idem, 23.ix.1975, idem (3 fêmeas, DZUP); idem, 8.x.1975, mesmo col (1 fêmea. DZUP); idem, 15.x.1975, idem (2 fêmeas, DZUP); idem, 5.xi.1975, mesmo col (16 fêmeas, DZUP); idem, 12.xi.1975, idem (8 fêmeas, DZUP); idem, 26.xi.1975, idem (1 fêmea, DZUP); idem, 3.xii.1975, idem (1 fêmea, DZUP); idem, 10.xii.1975, idem (12 fêmeas, DZUP); idem, 17.xii.1975, idem (7 fêmeas, DZUP); idem, 14.i.1976, idem (1 fêmea, DZUP); idem, 16.i.1976, idem (1 fêmea, DZUP); idem, 11.ii.1976, idem (2 fêmeas, DZUP); idem, 15.ii.1976, idem (1 fêmea, DZUP); idem, 6.3.1976, idem (1 fêmea, DZUP); idem, 20.iii.1976, idem (1 fêmea, DZUP); Curitiba, Santa. Felicidade, 4.vi.1975, A. Imbiriba col. (6 fêmeas, DZUP); idem, 13.vii. 1975, idem (1 fêmea, DZUP); idem, 20.vii.1975, idem (2 fêmeas, DZUP); idem, 27.xii.1975, idem (1 fêmea, DZUP); idem, 3.ix.1975, idem (18 fêmeas, DZUP); idem, 10.ix.1975, idem (3 fêmeas, DZUP); idem, 8.x.1975 (1 fêmea, DZUP); idem, 15.x.1975, idem (1 fêmea, DZUP); idem, 17.xii.1975, idem (1 fêmea, DZUP); Curitiba, Uberaba, 27.viii.1975, A. Imbiriba col. (1 fêmea, DZUP); idem, 17.ix.1975, idem (2 machos, DZUP); idem, 23.ix.1975, idem (2 machos, DZUP); idem, 25.ix.1975, idem (1 fêmea, DZUP); idem, 9.x.1975, idem (1 macho, DZUP); idem, 29.x.1975, idem (1 fêmea, DZUP); idem, 12.xi.1975, idem (2 machos,1 fêmea, DZUP); idem, 13.xi.1975, idem (1 macho, 1 fêmea, DZUP); idem, 20.xi.1975, idem (1 macho, 4 fêmeas, DZUP); idem, 3.xii.1975, idem (1 macho, DZUP); Curitiba, 29.xi.1980, C. B. Jesus col. (1 fêmea, DZUP); idem, 31.i.1981, mesmo col. (2 fêmeas, ZUP); Santa Catarina: Nova Teotônia, x.1965, F. Plaumann col. (1 fêmea, DZUP); Nova Teotônia, $27^{\circ} 11$ B $52^{\circ} 23$ L, 300-500 m, xi.1971, F. Plaumann col. (2 fêmeas, DZUP).

Distribuição geográfica: Região Neotropical: Peru, Bolívia, Chile, Brasil, Argentina, Ilhas Malvinas. Introduzida na África do Sul, Austrália e Nova Zelândia, provavelmente através do comércio (Carvalho et al. 2003).

Brasil: São Paulo, Paraná, Santa Catarina.

Fannia canicularis (Linnaeus, 1761)

(Figs. 1, 3, 39, 52, 57, 71, 90, 107, 122, 134, 153, 172, 191, 210, 229 e 244)

Diagnose: Tíbia posterior na face anterodorsal com uma série de cerdas pequenas a partir do terço basal. Macho apresenta cerda orbital superior. Fêmea apresenta o tórax acinzentado, dorsalmente com três listras dorsais estreitas acastanhadas e abdome com os tergitos I-III amarelos.

Redescrição: Macho: comprimento total 5,3-6,8 mm (N=7); asa 4,5-6,0 $\mathrm{mm}(\mathrm{N}=7)$. Holóptico. Olhos nus. Cerdas frontais em número de dez a 12 pares (Fig. 3). Cerda orbital superior presente (Fig. 3). Placa fronto-orbital, parafaciália, vita frontal, gena e face com forte polinosidade prateada. Escapo e pedicelo negros. Flagelômero negro com polinosidade cinza. Arista com fraca pubescência e castanho-escura. Palpo castanho-escuro e clavado, com o ápice medindo cerca de duas vezes a largura da base. Tórax acinzentado, dorsalmente com três listras dorsais castanho-claras, as quais coincidem com as dorsocentrais e acrosticais e estendem-se até a base do escutelo (Fig. 52), mas às vezes apresentam-se pouco nítidas. Escutelo castanho-cinzento. Caliptras esbranquiçadas com as margens amareladas. Halter branco-amarelado a amarelo. Asa amarelada. Duas cerdas pré-alares. Pernas castanho-escuras. Tíbia média na face ventral com fraca pubescência; face posterodorsal com uma cerda submediana. Coxa posterior na face posterior com três cílios. Fêmur posterior nas faces ventral e posteroventral sem cerdas diferenciadas e sem protuberância pré-apical (Fig. 90). Tíbia posterior na face anteroventral com uma a três cerdas medianas; face anterodorsal com uma série de cerdas pequenas a partir do terço basal (Fig. 71). Abdome alongado, castanho-escuro ou acinzentado com os tergitos IIII ou até o tergito IV amarelo-translúcidos lateralmente, podendo apresentar uma listra mediana mais escura (Fig. 107). Esternito I ciliado. Esternito V (Fig. 134). Terminália (Figs. 153 e 172): epândrio mais largo que longo, coberto por esparsas cerdas de diferentes tamanhos; surstilo alargado na base e afilado no ápice com diversos cílios, e uma projeção mediana na qual apresenta um tufo de cerdas longas e sinuosas Processo baciliforme ausente. Hipândrio e estruturas associadas (Figs. 191 e 210).

Fêmea semelhante ao macho, exceto: comprimento total 4,5-6,2 mm ( $\mathrm{N}=5)$; asa 4,3-5,8 $\mathrm{mm}(\mathrm{N}=5)$. Dicóptica. Cerdas frontais em número de sete pares de diferentes tamanhos (Fig. 39). Cerda orbital inferior divergente (Fig. 39). Placa frontoorbital com uma a duas séries de cílios. Tórax acinzentado, dorsalmente com três listras dorsais estreitas acastanhadas (Fig. 57). Abdome cordiforme, castanho-acinzentado com o tergito II e às vezes a base do tergito III amarelos (Fig. 122). Terminália (Fig. 229): cercos 1,5 vezes o comprimento da placa anal, coberto por cerdas de diversos tamanhos, sendo as apicais maiores; placa anal quase tão longa quanto larga; coberta por longas cerdas; esternito VIII reduzido em um par de placas posteriores ciliadas e outro par de placas anteriores nuas; esternitos VII e VI tão largos quanto longos com uma série horizontal de cílios na porção apical. Duas espermatecas esféricas e não estriadas (Fig. 244).

Comentários: F. canicularis pertence ao subgrupo canicularis do grupo canicularis. Este subgrupo é caracterizado, principalmente, por apresentar olho nu, parafaciália nua, coxa posterior na face posterior ciliada, cerda 

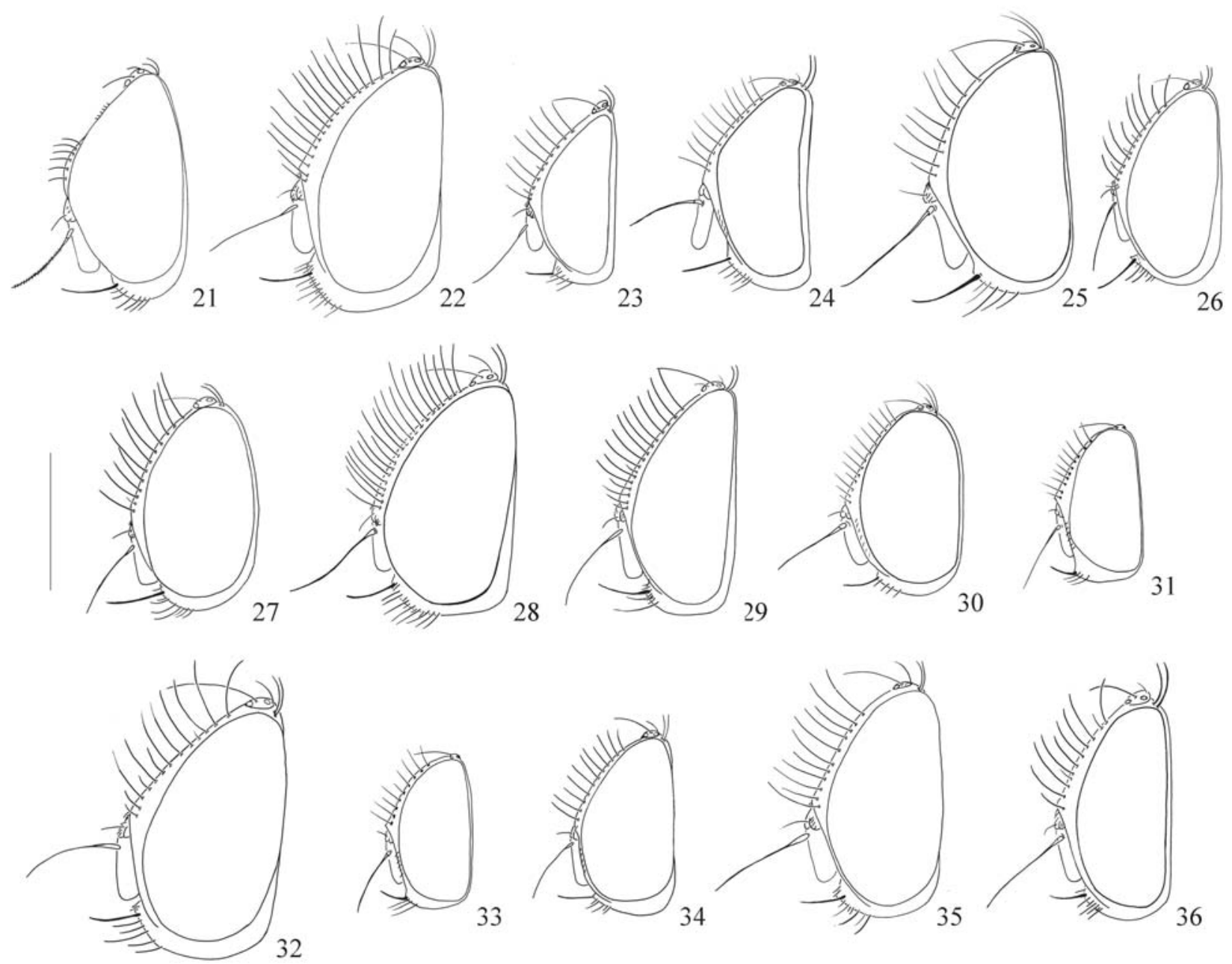

Figs. 21-36. Cabeça, vista lateral, macho: 21, F. admirabilis; 22, F. albitarsis; 23, F. carvalhoi; 24, F. femoralis; 25, F. flavicincta; 26, F. heydenii; 27, F. itatiaiensis; 28, F. obscurinervis; 29, F. penicillaris; 30, F. pusio; 31, F. sabroskyi; 32, F. scalaris; $33, F$. snyderi; 34, F. trimaculata; 35, F. tumidifemur; 36, F. yenhedi. Escala: $1 \mathrm{~mm}$.

orbital superior presente, processo baciliforme ausente, edeago membranoso e duas espermatecas (Chillcott 1961; Albuquerque et al. 1981).

Biologia: Espécie sinantrópica (Bruno et al. 1992, 1993; Carvalho et al. 2002).

As larvas de $F$. canicularis se desenvolvem em diversos tipos de matéria orgânica como fungos, matéria vegetal em decomposição ou associada a ninhos de himenópteros e pássaros (Chillcott 1961), depósito de lixo urbano (Queiroz \& Carvalho 1987) e fezes de aves poedeiras (Bruno et al. 1993; Mullens et al. 2002). Os adultos podem ser coletados em armadilhas com fígado de galinha e cebola em decomposição (Almeida et al. 1985), e sardinha (Leandro \& d'Almeida 2005).

Material-tipo (não examinado). Lectótipo macho, depositado no Linnean Society United Kingdom (LSUK), em Londres, Inglaterra (Carvalho et al. 2003).

Material examinado: Brasil. São Paulo: Ibiúna, i.1986, T. V. Bruno (1 macho, 1 fêmea, DZUP); Paraná: Curitiba, 26.ix.1972, M. C. Leal (2 machos, DZUP); idem, 26.x.1972. V. Almeida col. (1 macho, DZUP); idem, 20.xii.1980, C. B. Jesus col. (1 macho, DZUP); idem, 3.ix.1982,
C. J. B. de Carvalho col. (1 macho, DZUP); Curitiba, Santa Felicidade, 15.x.1975, A. Imbiriba col. (1 fêmea, DZUP); idem, 3.xii.1975, idem (1 fêmea, DZUP); Curitiba, Uberaba, 25.ix.1975, A. Imbiriba col. (1 fêmea, DZUP); idem, 23.x.1975, idem (1 fêmea, DZUP); idem, 6.xi.1975, idem (1 fêmea, DZUP); idem, 19.xi.1975, idem (1 fêmea, DZUP); idem, 21.i.1976, idem (1 macho, DZUP); Estrada do Cerne, Km 11, 8.x.1975, A. Imbiriba col. (1 fêmea, DZUP); idem, 10.x.1975, idem (1 fêmea, DZUP); idem, 20.x.1975, idem (2 macho, 1 fêmea, DZUP); idem, 13.iii.1976, idem (1 macho, DZUP); idem, 17.iv.1976, idem (1 fêmea, DZUP); Morretes, 975 m, 12.xii.1969, Moure \& Giacomel col. (1 fêmea, DZUP); Santa Catarina: Rio das Antas, i.1953, Camargo col. (1 macho, MZSP). Rio Grande do Sul: Pelotas, 11.viii.2006, L. D. Wendt (9 machos, 8 fêmeas, DZUP)

Distribuição geográfica: Cosmopolita (Chillcott 1961; Carvalho et al. 2003).

\section{Fannia carvalhoi Couri, 2005}

(Figs. 23, 65, 72, 91, 108, 135, 154, 173, 192, 211)

Diagnose: Tórax inteiramente castanho escuro e asa levemente acastanhada. Macho com a tíbia média na face ventral com forte constrição no terço basal, e a tíbia posterior 
na face ventral com forte cerda pré-apical. Fêmea com abdome castanho-escuro com manchas laterais e basais amarelas nos tergitos I-IV.

Redescrição: Macho: Comprimento total de 4,0-4,2 mm $(\mathrm{N}=2)$; asa 4,2-4,4 mm (N=2). Holóptico Olhos nus. Cerdas frontais em número de nove a 14 pares (Fig. 23). Placa frontoorbital, vita frontal, parafrontália, gena e face castanho-escuras. Escapo, pedicelo e arista negros. Flagelômero negro com densa polinosidade cinza. Arista com fraca pubescência. Palpo castanho-escuro e clavado, com o ápice medindo cerca de 1,5 vezes a base. Tórax inteiramente castanho-escuro. Caliptras branco-amareladas. Halteres amarelos. Asa levemente acastanhada. Pernas castanhas. Fêmur anterior na face posterodorsal com uma série completa de cerdas. Tíbia anterior na face anterodorsal com uma cerda submediana. Tíbia média (Fig. 65) na face ventral com forte constrição basal e no terço basal e com forte pubescência; face posterior com uma cerda submediana; face posteroventral com uma forte cerda apical. Coxa posterior na face posterior com dois cílios. Fêmur posterior alargado pré-apicalmente formando uma protuberância com um tufo de cerdas sobre as faces anteroventral (Fig. 72) e posteroventral (Fig. 91). Tíbia posterior na face ventral com uma cerda pré-apical forte, curva e longa. Basitarso posterior na face posterior com uma reentrância formando uma "dobra" apicalmente (Fig. 91). Abdome castanho-escuro com manchas laterais e basais amarelas nos tergitos III-IV (Fig. 107). Esternito I ciliado. Esternito V com a porção apical fortemente côncava, em forma de "U”' (Fig. 135). Terminália (Figs. 154, 173): epândrio quase tão longo quanto largo, levemente em forma de "sino", suavemente alargado na margem posterior, coberto por cerdas de diferentes tamanhos; surstilo longo, cerca de 1,5 vezes o tamanho do epândrio, bastante afilado apicalmente, face ventral pré-apical com uma projeção forte em forma de espinho; placa cercal uniformemente coberta por cerdas de mesmo tamanho; processo baciliforme afilado e alongado. Hipândrio e estruturas associadas (Figs. 192, 211).

Fêmea semelhante ao macho, exceto: Comprimento total 4.0-4,3 mm ( $\mathrm{N}=2)$; asa 4,4 mm ( $\mathrm{N}=2)$. Dicóptica. Tíbia média na face ventral sem constrição. Fêmur posterior sem a forte protuberância pré-apical e o tufo de cerdas. Tíbia posterior nas faces anterodorsal e posterodorsal com uma cerda mediana, inseridas ao mesmo nível; face posterodorsal com uma cerda pré-apical e face ventral com uma apical, não diferenciadas como nos machos. Abdome como nos machos, porém os tergitos I-II também são amarelos até a metade basal (Couri, 2005: fig 2). Terminália (ver Couri 2005: figs. 10-12).

Comentários: Os exemplares da região Sul do Brasil apresentaram variação no número de cerdas frontais em relação ao material-tipo proveniente do Peru. Contudo, esta diferença foi considerada uma variação intraespecífica, devido a grande semelhança nos demais caracteres, os quais só ocorrem nesta espécie, principalmente nos caracteres da terminália.

Primeiro registro para o Brasil.
Biologia: Não há dados de biologia na literatura para $F$. carvalhoi.

Material-tipo examinado: Holótipo macho (MNRJ): 'Peru: Junin Provin $\backslash 15 \mathrm{Km}$. W. San Ramon\1433m. asynanthropic 5 5.7.1980 Leg. M. Sayaka \& B. Greenberg'

Parátipos: '[mesma etiqueta do holótipo]' (1 macho, MNRJ); 'Peru: Junin Provin $\backslash 23$ Km. W. San. Ramon\1869m. asynathropic $1.7 .1980 \backslash$ Leg. M. Sayaka \& B. Greenberg' (1 macho, MNRJ); 'Peru: Junin Provin\ $20 \mathrm{Km}$. W. San. Rason $\backslash 1869 \mathrm{~m}$. asynathropic $30.6 .1980 \backslash \mathrm{Leg} . \mathrm{M}$. Sayaka \& B. Greenberg' (2 fêmeas, MNRJ); 'Peru: Junin Provin\ 18 Km. W. San. Ramon\1869m. asynathropic $5.7 .1980 \backslash$ Leg. M. Sayaka \& B. Greenberg' (1 fêmea, MNRJ).

Material adicional examinado: Brasil. Paraná: Pinhão, Salto Segredo, 19.i.92, R. Misiuta col. (1 macho, DZUP); Ponta Grossa, Vila Velha, IAPAR, 28.viii.2000, Ganho \& Marinoni col. (1 macho, DZUP).

Distribuição geográfica: Peru e Brasil (Paraná).

Fannia femoralis (Stein, 1898)

(Figs. 24, 73, 92, 136, 155, 174, 212)

Diagnose: Macho apresenta o fêmur posterior na face ventral com uma forte protuberância pré-apical, na qual se inserem nas faces ventral, anteroventral e posteroventral cerdas longas, formando um tufo. Fêmea apresenta placa frontoorbital negra brilhante com uma estreita faixa próxima aos olhos coberta por polinosidade prateada.

Redescrição: Macho: Comprimento total 3,0-3,5 mm (N=2); Asa 2,8-3,2 mm (N=2). Holóptico. Olhos nus. Cerdas frontais em número de 11 a 12 (Fig. 24). Parafaciália com uma série de pequenos cílios. Placa fronto-orbital, vita frontal, parafaciália, gena e face com polinosidade prateada. Escapo e pedicelo negros. Flagelômero coberto com forte polinosidade cinzaescura. Arista com fraca pubescência e castanho-escura. Palpo castanho-escuro e filiforme, ápice de mesma largura da base. Tórax negro. Caliptras e halter branco-amarelados. Asa amarelada. Duas pré-alares. Pernas castanho-escuras. Coxa posterior na face posterior com dois cílios. Fêmur posterior na face ventral com forte protuberância pré-apical, na qual se inserem nas faces ventral, anteroventral (Fig. 73) e posteroventral (Fig. 92) cerdas longas, formando um tufo. Tíbia posterior na face anterodorsal com uma série de quatro a cinco cerdas (Fig. 73); face anteroventral com uma a duas cerdas medianas (Fig. 73) Abdome trimaculado (padrão para o subgrupo pusio (Chillcott 1961), ver redescrição de F. pusio, figura 116). Estenito I nu. Esternito V (Fig. 136). Terminália (Figs. 174, 255) padrão para o subgrupo pusio: epândrio pouco mais largo que longo, levemente hemisférico, com cerdas de diferentes tamanhos; surstilo curto inteiramente fusionado apicalmente ao epândrio, apresentando uma projeção lateroventral com cerdas fortes; placa cercal cordiforme, fusionada na porção média; processo baciliforme ausente. Hipândrio e estruturas associadas (Figs. 193, 212).

Fêmea semelhante ao macho, exceto: Comprimento total 3,0-3,2 mm ( $\mathrm{N}=2)$; Asa 2,7-3,0 mm ( $\mathrm{N}=2)$. Dicóptica. Cerdas frontais pequenas em número de dez pares. Placa fronto-orbital negra brilhante com uma estreita faixa próxima aos olhos 

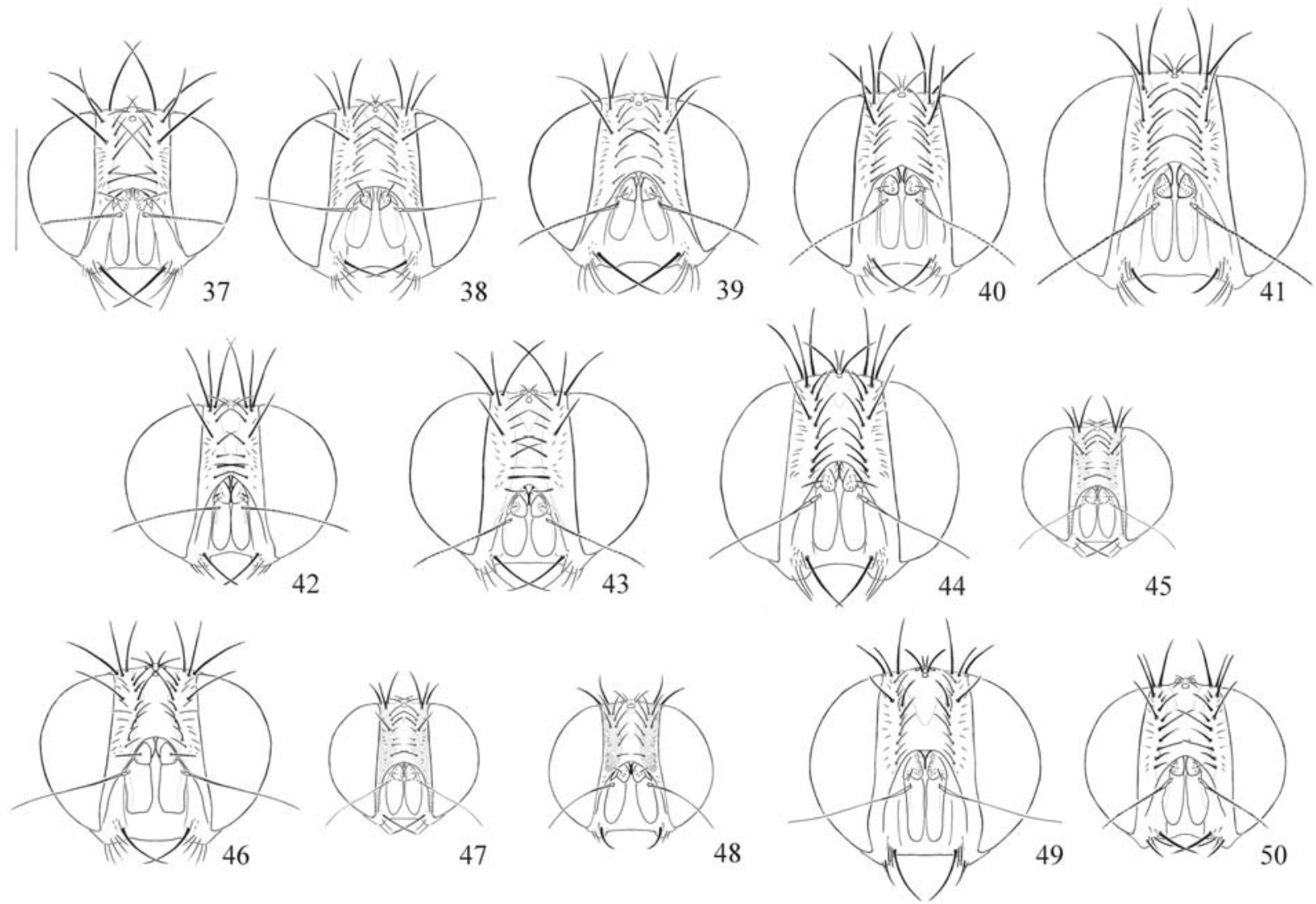

Figs. 37-50. Cabeça, vista frontal, fêmea: 37, F. admirabilis; 38, F. albitarsis; 39, F. canicularis; 40, F. flavicincta; 41, F. heydenii; 42, F. itatiaiensis; 43, F. obscurinervis; 44, F. punctipennis; 45, F. pusio; 46, F. scalaris; 47, F. snyderi; 48, F. trimaculata; 49, F. xanthocera; 50, F. yenhedi. Escala: $1 \mathrm{~mm}$.

coberta por polinosidade prateada. Fêmur posterior na face ventral sem protuberância pré-apical. Abdome negro (padrão para o subgrupo pusio, ver F. pusio) (Chillcott 1961: fig. 127). Terminália (padrão para o subgrupo pusio, segundo Chillcott (1961): cercos curtos e largos; placa anal mais larga que longa e ciliada; esternito VIII reduzido a duas placas ciliadas; esternitos VII e VI muito mais largos que longos. Duas espermatecas ovais, um pouco alongadas na forma, com um recorte apical, e superfície rugosa (ver Chillcott 1961: fig. 210).

Comentários: F. femoralis pertence ao grupo canicularis (subgrupo pusio) (Chillcott 1961; Albuquerque et al. 1981). Este subgrupo é caracterizado, principalmente, por apresentar parafaciália com uma série de pequenos cílios, cerda orbital superior ausente, abdome trimaculado, processo baciliforme ausente (Chillcot 1961). Estes caracteres são constantes entre as espécies do subgrupo pusio. Os machos são identificados através das diferenças no fêmur posterior quanto a sua forma, presença e posição de cerdas, e na terminália. Entretanto, as fêmeas são bastante similares entre si, devido a perda dos caracteres secundários e, na maioria das vezes, são de difícil identificação.

Primeiro registro para Santa Catarina e Rio Grande do Sul.

Biologia: Espécie de hábito sinantrópico (Carvalho et al. 2002).
Material-tipo (não examinado). Síntipos machos depositados no Field Museum of Natural History (FMNH), em Chicago, Estados Unidos (Carvalho et al. 2003).

Material examinado: Brasil. Rio de Janeiro: Angra dos Reis, 20.iii.1971, H. S. Lopes col. (1 fêmea, MNRJ); Nova Friburgo, i.1946, Wygod col. (1 macho, 1 fêmea, MNRJ); Santa Catarina: Nova Teotônia, xi.1971, F. Plauman col. (1 macho, MZSP); Rio Grande do Sul: Capão do Leão, Barragem da Eclusa, R. F. Krüger col. (1 macho, DZUP).

Distribuição geográfica: América do Norte, Cuba, Ilhas Virgens, Porto Rico, Haiti, República Dominicana, Guiana, Bolívia, Peru, Argentina e Brasil (Carvalho et al. 2003).

Brasil: Rio de Janeiro, São Paulo, Paraná, Santa Catarina, Rio Grande do Sul.

\section{Fannia flavicincta Stein, 1904}

(Figs. 5, 25, 40, 53, 58, 74, 93, 109, 123, 137, 156, 175, 194, 213, 230, 245)

Diagnose: Tíbia média na face posterior com duas cerdas medianas; tíbia posterior na face anteroventral com cinco a sete cerdas e esternito I nu. Macho com dez a 11 pares cerdas frontais.

Redescrição: Macho: Comprimento total de 5,5-6,5 mm $(\mathrm{N}=6)$; asa 5,0-5,5 mm ( $\mathrm{N}=6)$. Holóptico. Olhos nus. Cerdas 
frontais de dez a 11 pares (Fig. 25). Vita frontal negra. Placa fronto-orbital, parafaciália, gena e face com forte polinosidade prateada. Escapo, ápice do pedicelo e ápice da arista castanhoescuros. Base do pedicelo e base da arista amareladas. Flagelômero negro com polinosidade cinza-escura. Arista com fraca pubescência. Palpo castanho-escuro e clavado, com o ápice medindo cerca de 1,5 vezes a largura da base. Escuto pré-suturalmente castanho-escuro com duas listras acizentadas medianas e pós-suturalmente castanho-claro sem listras (Fig. 53). Escutelo inteiramente castanho ou a base castanha e ápice castanho-acinzentado. Pleuras acinzentadas. Caliptras branco-amareladas com borda amarela. Halter esbranquiçado ou branco-amarelado. Asa amarelada. Uma préalar. Pernas castanho-escuras. Pulvilos pequenos e amarelados. Fêmur anterior na face posteroventral com uma série de cerdas a partir do terço apical; face posterodorsal com uma série completa de cerdas curtas e espaçadas entre si. Tíbia média na face posterior com duas cerdas medianas. Coxa posterior na face posterior com dois a três cílios. Fêmur posterior na face posteroventral com um fraco conjunto pré-apical de cerdas finas e de ápice curvo (Fig. 93). Tíbia posterior na face anteroventral com cinco a sete cerdas (Fig. 74); face anterior com duas cerdas medianas (Fig. 74). Tergitos I-IV lateralmente amarelo-translúcidos, com uma listra mediana castanho-escura estendendo-se lateralmente na metade apical; tergito $\mathrm{V}$ inteiramente castanho-acinzentado (Fig. 109). Esternito I nu. Esternito V (Fig. 137). Terminália padrão do grupo heydenii (Figs. 156 e 175): epândrio mais longo que largo com cerdas de diferentes tamanhos; surstilos irregulares, estreitamente fusionados ao epândrio, com um sulco na porção mediana e fortemente afilado no ápice; processo baciliforme cuneiforme. Hipândrio e estruturas associadas (Figs. 194, 213).

Fêmea similar ao macho, exceto: Comprimento total 5,0-6,0 $\mathrm{mm}(\mathrm{N}=5)$; asa 4,0-5,0 mm $(\mathrm{N}=5)$. Dicóptica. Cerdas frontais em número de cinco a seis pares, intercaladas por cílios menores; cerdas orbital inferior e superior voltadas para a porção posterior da cabeça (Fig. 40). Escuto castanho com duas listras acinzentadas que se estendem nitidamente até a base do escutelo (Fig. 58). Fêmur posterior na face posteroventral sem cerdas diferenciadas pré-apicalmente. Tíbia posterior na face anteroventral com quatro a seis cerdas. Abdome castanho com manchas basais amareladas (Fig. 123). Terminália padrão do grupo heydenii (Fig. 230): cercos longos, cerca de duas vezes a altura da placa anal e com cerdas de diferentes tamanhos; placa anal mais longa que larga; esternito VIII reduzido em duas placas esclerotinizadas ciliadas; esternito VII e VI mais longos que largos. Duas espermatecas ligeiramente alongadas e rugosas (Fig. 245).

Comentários: F. flavicincta pertence ao grupo heydenii, cujos machos são caracterizados por apresentar os primeiros tergitos amarelo-translúcidos, coxa posterior ciliada, processo baciliforme cuneiforme. As fêmeas apresentam esternitos VIVII mais longos que largos, esternito VIII reduzido a dois pequenos escleritos ou ausente, e duas espermatecas (Albuquerque et al. 1981).
Biologia: F. flavicinta possui hábito sinantrópico, entretanto, é mais comum em áreas rurais do que em áreas urbanas (Almeida et al. 1985). É coletada em armadilhas com fígado de galinha e cebola em decomposição (Almeida et al. 1985), sardinha (Leandro \& D’ Almeida 2005).

Esta espécie é regitrada como vetora de ovos de Dermatobia hominis (Espindola \& Couri 2004).

Material-tipo (não examinado). Síntipo macho não encontrado no Museum für Naturkunde der Humboldt-Universität, na Alemanha e do Hungarian Natural History Museum, Hungria encontra-se destruído (Carvalho et al. 2003).

Material examinado: Brasil. São Paulo: Castilho, margem esquerda da Rio Paraná, 1.xii.1964, Exp. Departamento de Zoologia col. (1 macho, DZUP); Porto Cabral, Rio Paraná, 6-15.x.1941, L. Travassos Filho col (1 macho, DZUP); idem, 1-10.xi.1941, idem (1 macho, DZUP); idem, iii-iv.1944, idem (1 macho, MNRJ); Teodoro Sampaio, Parque Estadual do Morro do Diabo, Trilha Grupo 6, 6-8.ix.2002, V. C. Silva col. (1 macho, 11 fêmeas, DZUP); idem, 24-30.ix.2002, idem (1 macho, DZUP); idem, 30.ix-4.x.2002, idem (3 machos, DZUP); Paraná: Fênix, Reserva Biológica Sapitundava, 11.iv.1988, Levantamento Entomológico PROFAUPAR col. (1 macho, 1 fêmea, DZUP); idem, 16.v.1988, idem (1 fêmea, DZUP); idem, 6.vi.1988, idem (1 fêmea, DZUP); Fênix, Reserva Estadual Vila Rica, 20.v.1988, idem (2 fêmeas, DZUP); idem, 27.v.1988, idem (1 fêmea); Foz do Iguaçu, xii.1941, Com. E. N. V. col. (1 macho, MNRJ); idem, 7.xii.1966, Exc. Departamento de Zoologia col. (1 macho, DZUP).

Distribuição geográfica: Colômbia, Peru, Bolívia e Brasil (Carvalho et al. 2003).

Brasil: Goiás, Minas Gerais, Mato Grosso, Rio de Janeiro, São Paulo, Paraná.

\section{Fannia heydenii (Weidemann, 1830)}

(Figs. 26, 41, 54, 59, 75, 94, 110, 138, 157, 176, 195, 214, 231, 246)

Diagnose: Escuto acinzentado com três listras castanhas, as quais correspondem com as dorsocentrais e acrosticais e estendem-se à base do escutelo; tíbia média na face posterior com uma cerda submediana. Macho com fêmur posterior na face posteroventral com forte protuberância pré-apical onde se inserem um conjunto de cerdas longas, fortes e de ápice curvo.

Redescrição: Macho: comprimento total 5-5,5 mm (N=3); asa 4,3-5,2 mm (N=3). Holóptico. Olhos nus. Cerdas frontais em número de nove a dez pares (Fig. 26). Vita frontal negra ou prateada. Parafaciália, placa fronto-orbital, gena e face com forte polinosidade prateada. Escapo, pedicelo e base da arista castanho-claros. Ápice da arista castanho. Flagelômero castanho-escuro coberto com densa polinosidade acinzentada. Arista com fraca pubescência. Palpo negro e espatulado, com o ápice medindo cerca de 2,5 vezes a largura da base. Escuto castanho com duas listras acinzentadas que se estendem à base do escutelo (Fig. 54). Base do escutelo castanha e ápice acinzentado. Uma cerda pré-alar. Caliptras branco-amareladas com bordas amareladas a acastanhadas. Halter esbranquiçado. Asa amarelada. Fêmur anterior na face posteroventral com uma série de cerdas a partir do terço apical; face posterodorsal 

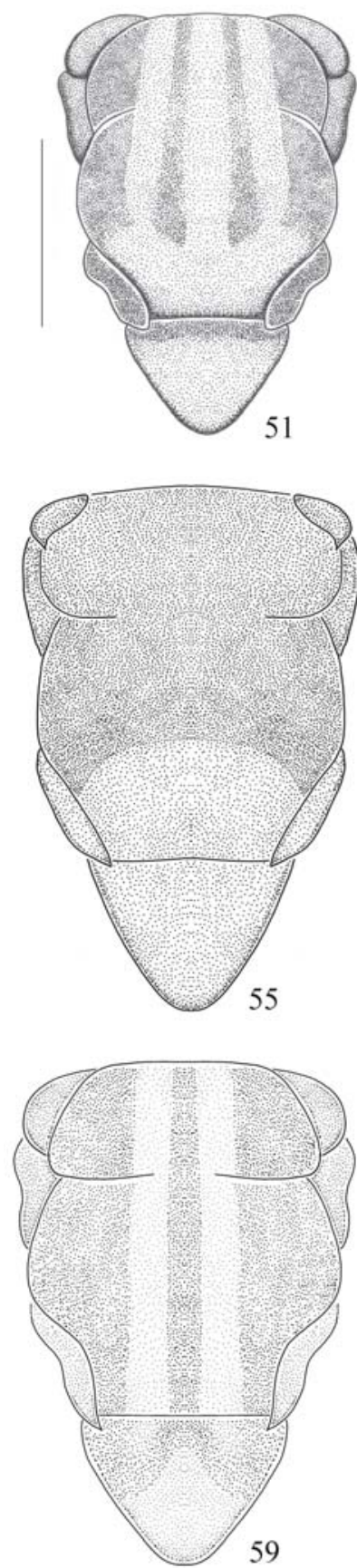
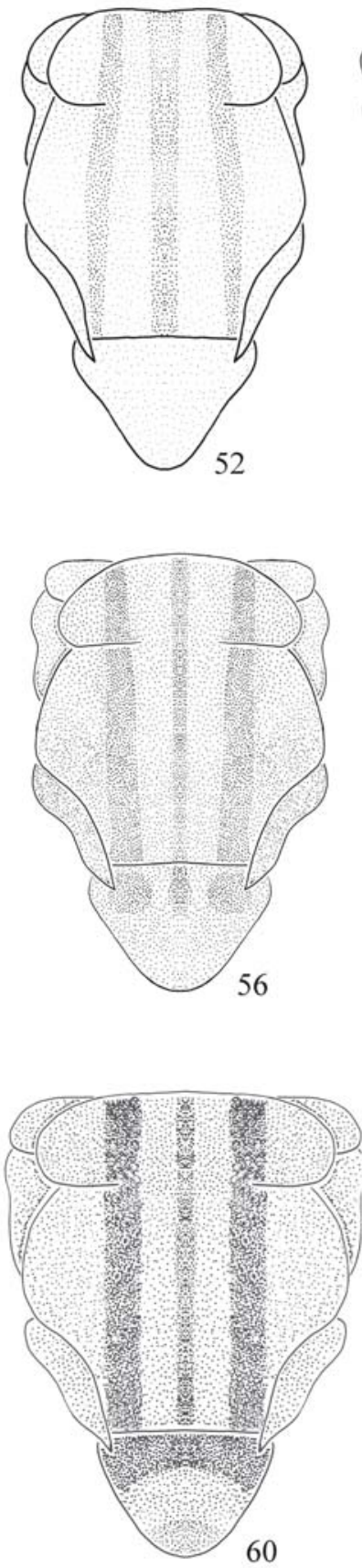
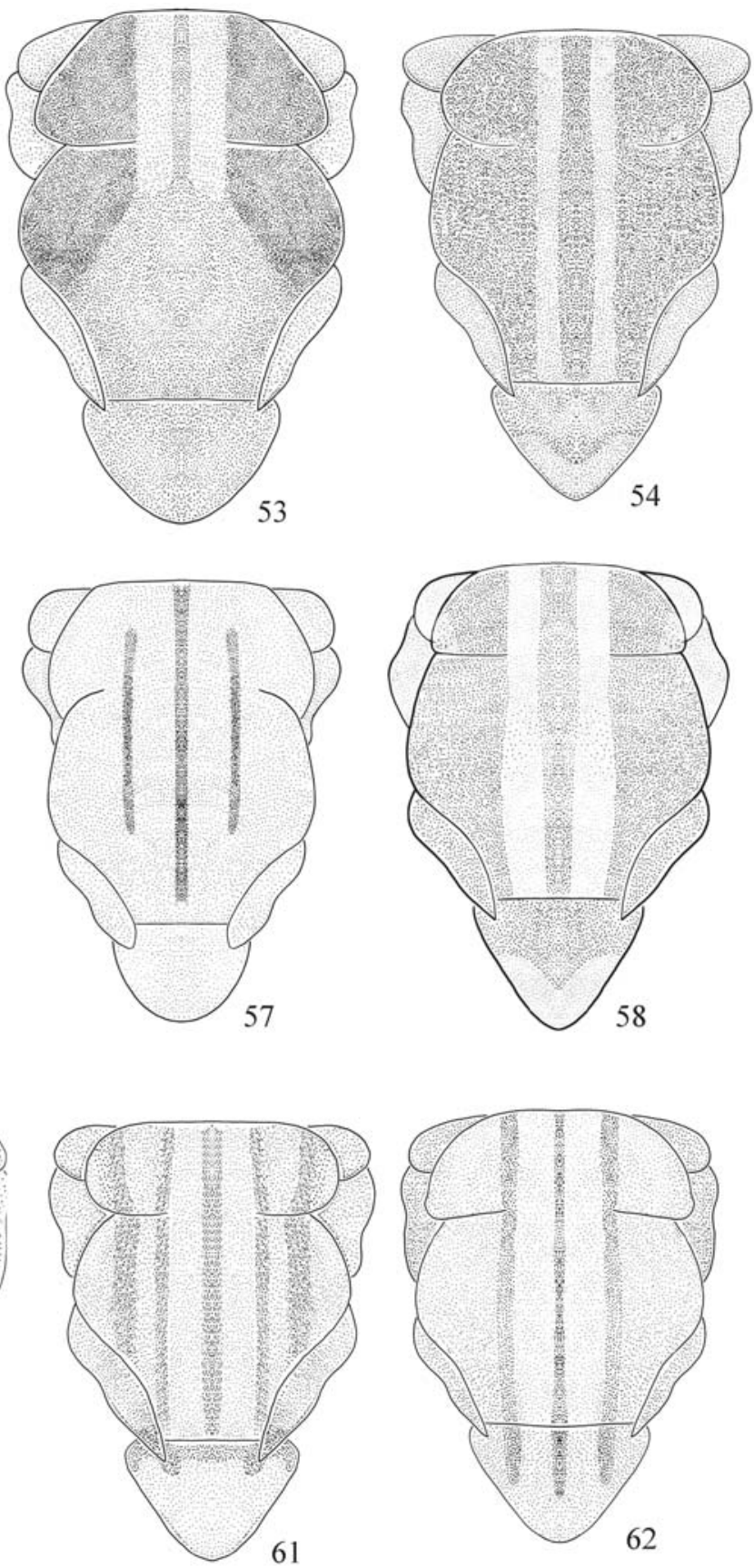

Figs. 51-62. Tórax, vista dorsal: 51-56: Macho: 51, F. albitarsis; 52, F. canicularis; 53, F. flavicincta; 54, F. heydenii; 55, F. penicillaris; 56, F. yenhedi; 57-62: Fêmea: 57, F. canicularis; 58, F. flavicincta; 59, F. heydenii; 60, F. punctipennis; 61, F. xanthocera; 62, F. yenhedi. Escala: 1 mm.

com uma série completa de cerdas curtas e espaçadas. Tíbia média na face posterior com uma cerda submediana. Coxa posterior na face posterior com dois cílios. Fêmur posterior na face posteroventral com forte protuberância pré-apical onde se inserem um conjunto de cerdas longas, fortes e de ápice curvo (Fig. 94). Tíbia posterior na face anteroventral com três a quatro cerdas (Fig. 75). Abdome alongado com tergitos I-IV lateralmente amarelo-translúcidos e com uma listra mediana castanho-escura, tergito V castanho acinzentado (Fig. 110).
Esternito I fracamente ciliado. Esternito V (Fig. 138). Terminália (Figs. 157, 176): padrão do grupo heydenii (ver redescrição de F. flavicincta). Hipândrio e estruturas associadas (Figs. 195, 214).

Fêmea semelhante ao macho, exceto: comprimento total 4,2-5,0 mm ( $\mathrm{N}=4)$; asa 4,0-4,8 mm ( $\mathrm{N}=4)$. Dicóptica. Cerdas frontais em número de oito a nove pares de diferentes tamanhos (Fig. 41). Parafaciália com uma série de cílios fracos. Cerdas orbital inferior e superior voltadas para a porção posterior da 


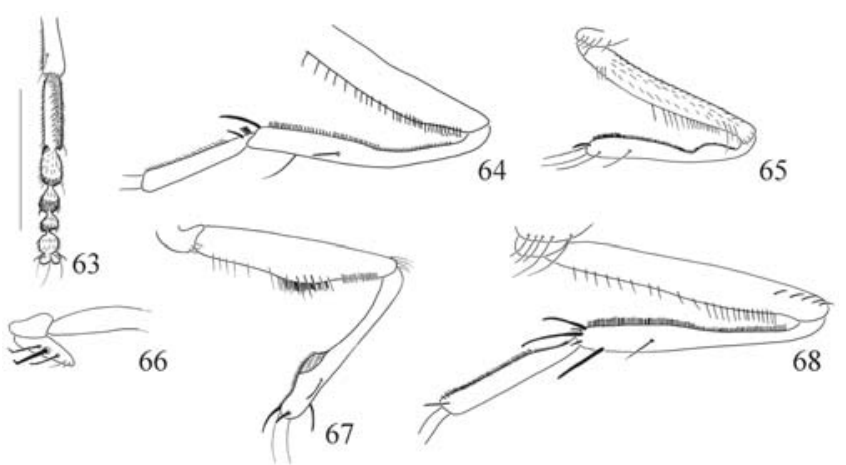

Figs. 63-68. Caracteres diagnósticos, macho: 63-64: F. albitarsis: 63, Tarsômeros anteriores, vista dorsal; 64, Perna média, vista posterior; 65, F. carvalhoi, perna média, vista anterior; 66-67: F. scalaris: 66, Coxa média, vista anterior; 67, Perna média, vista anterior; $68, F$. tumidifemur, perna média, vista posterior. Escala: $1 \mathrm{~mm}$.

cabeça. Escuto castanho com duas listras acinzentadas que se estendem até a base do escutelo (Fig. 59). Fêmur posterior na face anteroventral sem protuberância pré-apical. Terminália (Fig. 231): padrão do grupo heydenii (ver redescrição de $F$. flavicinta). Duas espermatecas levemente alongadas e rugosas (Fig. 246).

Comentários: $F$. heydenii pertece ao grupo heydenii (Albuquerque et al. 1981). Fêmea de F. heydenii é bastante similar à $F$. flavicincta, contudo, apresentam na tíbia média na face posterior apenas uma cerda.

Primeiro registro para Santa Catarina.

Biologia: Espécie considerada sinantrópica (Carvalho et al. 2002), sendo mais abundante em áreas rurais (Almeida et al. 1985).

Fannia heydenii possui grande importância epidemiológica na infestação de Dermatobia hominis, a mosca do berne, por apresentar forte potencial como vetora de ovos desta mosca (Guimarães \& Papavero 1994; Gomes et al. 2002). No material examinado proveniente do DZUP, foram encontrados três exemplares de $F$. heydenii com ovos de $D$. hominis.

Os adultos podem ser coletados em armadilhas iscadas com sardinha fresca, fígado de galinha e cebola em decomposição (Almeida et al. 1985), com fígado bovino em decomposição (Gomes et al. 2002), em carne e armadilha Malaise (dados de etiqueta).

Material-tipo (não examinado). Lectótipo macho do Muséum National d'Histoire Naturelle (MNHN), em Paris, França, e paralectótipos do Naturhistorisches Museum Wien (NMW), na Áustria e do Forschungsinstitut und Naturmuseum Senckenberg (SMFD) (Carvalho et al. 2003).

Material examinado: Brasil. Mato Grosso do Sul: Campo Grande, 13.ix.1999, W. W. Koller col. (2 machos, 6 fêmeas, DZUP); São Paulo: Teodoro Sampaio, Parque Estadual do Morro do Diabo, 6-8.ix.2002, V. C. Silva col. (1 fêmea, DZUP); idem, 23-30.ix.2002, idem (1 fêmea, DZUP); idem, 30.ix-4.xi.2002, idem (1 fêmea, DZUP); Paraná: Curitiba, 6.xii.1980, C. B. Jesus col. (1 fêmea, DZUP); idem 20.xii.1980, idem (1 fêmea, DZUP); idem, 24.i.1981, idem (1 macho, DZUP); idem, 11.iv.1981, idem (1 fêmea, DZUP); Curitiba, Capão da Imbuia, 12.ii.1985, [sem coletor] (1 fêmea, DZUP); Curitiba, 4-5.xii.1999, R. K. Yamazaki col. (1 fêmea, DZUP); Guaratuba, 7.ii.1965, C. Dipterologia col. (1 fêmea, DZUP); Guarapuava, Ponta Grossa, Vila Velha, IAPAR, 11.viii.1986 Levantamento Entomológico PROFAUPAR (3 fêmeas, DZUP); idem, 18.viii.1986, idem (2 fêmeas, DZUP); idem, 25.viii.1986, idem (2 fêmeas, DZUP); idem, 15.ix.1986, idem (1 fêmea, DZUP); idem, 22.ix.1986, idem (1 fêmea, DZUP); idem, 29.ix.1986, idem (1 fêmea, DZUP); idem, 6.x.1986, idem (1 fêmea, DZUP); idem, 13.x.1986, idem (2 fêmeas, DZUP); idem, 3.xi.1986, idem (10 fêmeas, DZUP); idem, 10.xi.1986, idem (5 fêmeas, DZUP); idem, 17.xi.1986, idem (2 fêmeas, DZUP); idem, 24.xi.1986, idem (8 fêmeas, DZUP); idem, 1.xii.1986, idem (1 fêmea, DZUP); idem, 8.xii.1986, idem (1 fêmea, DZUP); idem, 16.iii.1986, idem (1 fêmeas, DZUP); idem, 30.iii.1987, idem (1 fêmeas, DZUP); idem, 13.iv.1987, idem (1 fêmea, DZUP); idem, 6.ix.1999, Ganho \& Marinoni col. (9 fêmeas, DZUP); idem, 4.x.1999, idem (2 fêmeas, DZUP); idem, 20.ix.1999, idem (8 fêmeas, DZUP); idem, 27.ix.1999, idem (3 fêmeas, DZUP); idem, 18.x.1999, idem (7 fêmeas DZUP); idem, 25.x.1999, idem (18 fêmeas, DZUP); idem, 1.xi.1999, idem (62 fêmeas, DZUP); idem, 8.xi.1999, idem (22 fêmeas, DZUP); idem, 15.xi.1999, idem (1 fêmea, DZUP); idem, 22.xi.1999, idem (11fêmeas, DZUP); idem, 29.xi.1999, idem (14 fêmeas, DZUP); idem, 13.xii.1999, idem (5 fêmeas, DZUP); idem, 20.xii.1999, idem (10 fêmeas,DZUP); idem, 3.i.2000, idem (12 fêmeas, DZUP); idem, 10.i.2000, idem (4 fêmeas, DZUP); idem, 17.i.2000, idem (1 fêmea, DZUP); idem, 24.i.2000, idem (5 fêmeas, DZUP); idem, 31.i.2000, idem (4 fêmeas, DZUP); idem, 14.ii.2000, idem (1 fêmea, DZUP); idem, 17.iv.2000, idem (1 fêmea, DZUP); idem, 3.vii.2000, idem (6 fêmeas, DZUP); idem, 13.iii.2000, idem (3 fêmeas, DZUP); idem, 14.vii.2000, idem (20 fêmeas, DZUP); idem, 28.viii.2000, idem (1 fêmea, DZUP); Ouro Fino, 21.ii.1965, idem (1 fêmea, DZUP); Pinhão, Rio dos Touros, 15.i.1992, R. Misiuta col. (7 fêmeas, DZUP); Pinhão, Salto Segredo, 19.i.1992, idem (7 fêmeas DZUP); Pinhão, Vila C., 20.i.1992, idem (2 fêmeas, DZUP); Piraquara, 5.v.1974, J. Ferreira col. (1 fêmea, DZUP); idem, 9.v.1974, idem (2 fêmeas, DZUP); Santa Catarina: Florianópolis, vii.1960, Casemiro col. (6 fêmeas, MZSP); Nova Teotônia, iii.1967, F. Plauman col. (2 fêmeas, MZSP); idem, v.1970, idem (2 fêmeas, MZSP); idem, xi.1970, idem (5 fêmeas, MZSP); idem, iv.1970, idem (1 fêmea, MZSP); idem, x.1970, idem (1 fêmea, MZSP); Rio Grande do Sul: Pelotas, 5.v.1965, C. M. Biezanko col. (1 fêmea, MZSP).

Distribuição geográfica: Peru, Bolívia, Uruguai, Paraguai, Argentina e Brasil (Carvalho et al. 2003).

Brasil: Minas Gerais, Mato Grosso, Rio de Janeiro, São Paulo, Paraná, Santa Catarina e Rio Grande do Sul.

\section{Fannia itatiaiensis Albuquerque, 1956}

(Figs. 4, 16, 27, 42, 76, 95, 111, 124, 139, 158, 177, 196, 215, 232, 247)

Diagnose: Tórax inteiramente negro, halter amarelo, tíbia anterior na face posterior com uma cerda no terço apical. Macho com fêmur posterior face posteroventral com um grupo de poucas cerdas diferenciadas, as quais não formam um tufo.

Redescrição: Macho: Comprimento total de 4,4-4,6 mm $(\mathrm{N}=3)$; asa 4,0-4,5 $\mathrm{mm}(\mathrm{N}=3)$. Holóptico. Olhos nus. Cerdas frontais em número de oito a 11 pares (Fig. 27). Placa frontoorbital, vita frontal, parafaciália gena e face com forte polinosidade prateada. Escapo e pedicelo castanho-escuro. Flagelômero castanho com forte polinosidade cinzenta. Base da arista castanho-clara e ápice castanho-escuro, com fraca pubescência. Palpo castanho-escuro e clavado, com ápice 

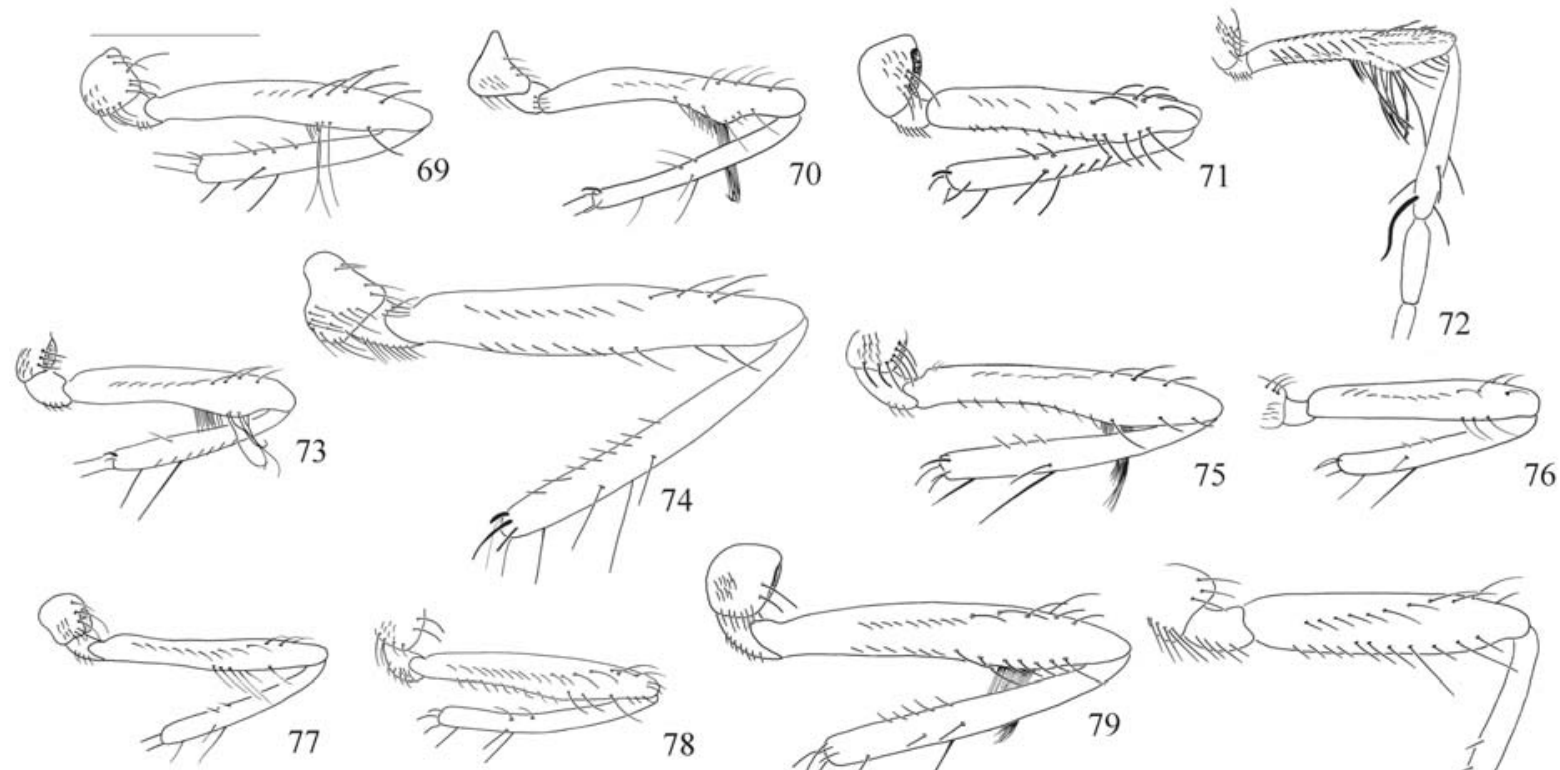

77

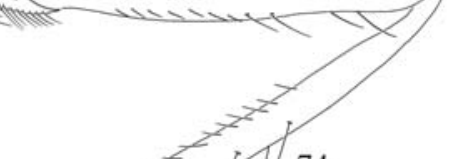

74
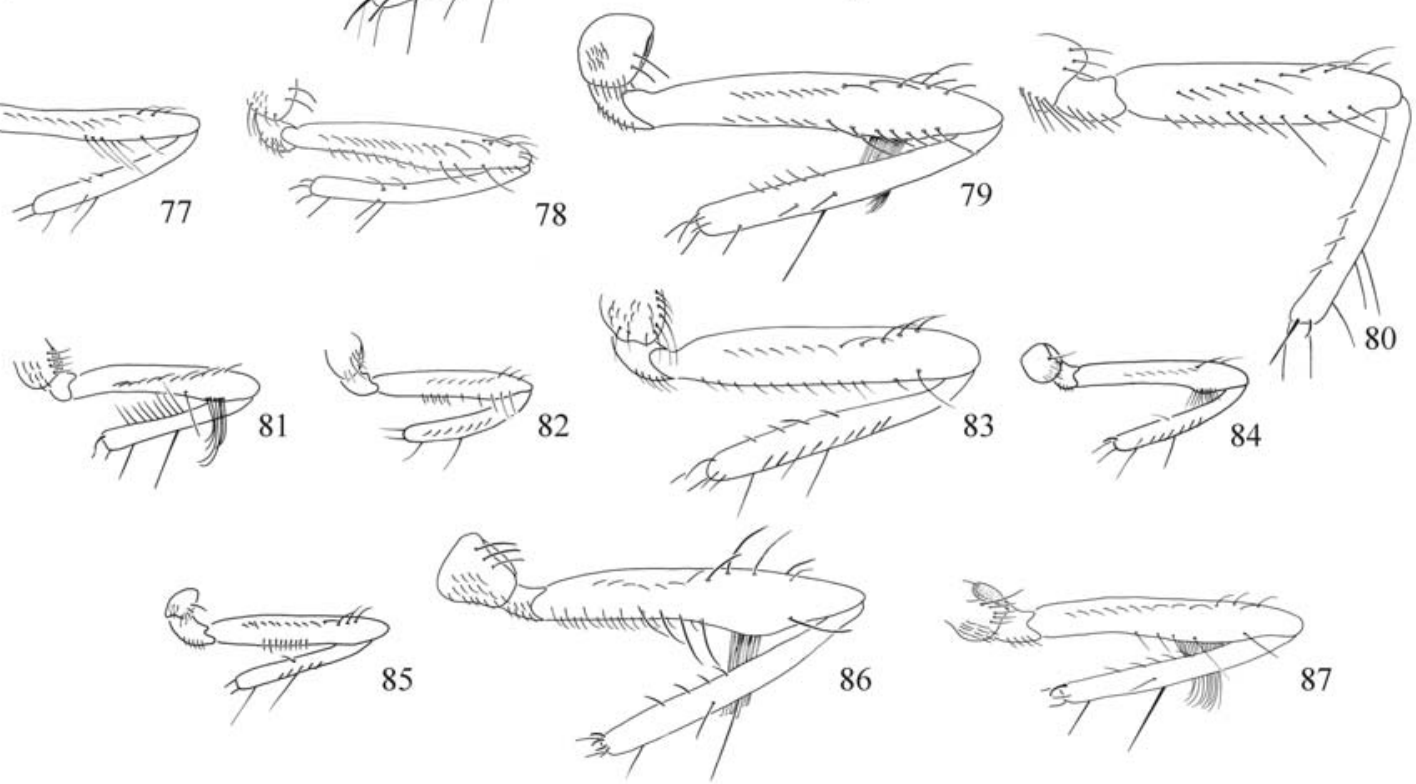

Figs. 69-87. Perna posterior, vista anterior, macho: 69, F. admirabilis; 70, F. albitarsis; 71, F. canicularis; 72, F. carvalhoi; 73, F. femoralis; 74, F. flavicincta; 75, F. heydenii; 76, F. itatiaiensis; 77, F. obscurinervis; 78, F. opsia sp. nov. 79, F. penicillaris; 80, F. pulvinilenis sp. nov. 81, F. pusio; 82, F. sabroskyi; 83, F. scalaris; 84, F. snyderi; 85, F. trimaculata; 86, F. tumidifemur; 87, F. yenhedi. Escala: 1 mm.

medindo cerca de 1,5 vezes o tamanho da largura da base. Tórax inteiramente negro. Duas pré-alares. Caliptras brancas. Halter amarelo. Asa castanha com fortes manchas na margem superior e nas veias transversais (Fig. 16). Pernas castanhoescuras; pulvilos pequenos e amarelados. Fêmur anterior na face posteroventral com uma série de cerdas, a partir do terço basal. Tíbia anterior na face posterior com uma cerda no terço apical. Tíbia média na face posterior com duas cerdas medianas. Coxa posterior na face posterior com uma ou duas cerdas. Fêmur posterior na face posteroventral com um fraco conjunto de cerdas diferenciadas, as quais não formam um tufo (Fig. 95). Tíbia posterior na face anteroventral com duas a três cerdas medianas (Fig. 76). Abdome negro com tergitos I-III com manchas amarelo-translúcidas (Fig. 111). Esternito I fortemente ciliado. Esternito V (Fig. 139). Terminália (Figs. 158 e 177): epândrio mais largo que longo coberto por cerdas curtas e de diferentes tamanhos; placa cercal afilada no ápice, com cerdas curtas até o terço apical, com cerdas longas e sinuosas no ápice; surstilos fortemente fusionados ao epândrio e afilados no ápice; processo baciliforme em forma de gancho. Hipândrio e estruturas associadas (Figs. 196 e 215).

Fêmea semelhante ao macho, exceto: comprimento total 4,2-4,6 mm (N=5); asa 4,0-4,4 mm ( $\mathrm{N}=5)$. Dicóptica. Cerdas frontais em número de dois pares, intercalados por diversos cílios (Fig. 42). Cerdas orbital superior e inferior voltadas para a porção posterior da cabeça (Fig. 42). Fêmur posterior na face posteroventral sem o conjunto de cerdas. Abdome inteiramente castanho-escuro brilhante (Fig. 124). Terminália (Fig. 232): cercos curtos, pouco maiores que a altura da placa anal e com cerdas longas; placa anal aproximadamente duas vezes mais larga que longa; esternito VIII reduzido a duas placas não ciliadas; esternito VII mais longo que largo e retangular; esternito VI mais largo que longo. Três espermatecas alongadas e rugosas (Fig. 247).

Comentários: $F$. itatiaiensis pertence ao grupo obscurinervis (Albuquerque et al. 1981). Este grupo é caracterizado por apresentar olhos esparsamente ciliados, asa 
acastanhada com a margem superior orladas de castanho e coxa posterior na face posterior ciliada. Os autores mencionaram que fêmeas deste grupo apresentam duas espermatecas, exceto Fannia hirtifemur (Stein 1904), na qual possui três espermatecas. Todavia, na descrição original de F. itatiaiensis Albuquerque (1956) não consta o número de espermatecas, mas todas as fêmeas de $F$. itatiaiensis dissecadas para este trabalho apresentaram três espermatecas.

Primeiro registro para o Paraná.

Material-tipo examinado: Holótipo fêmea (MNRJ): Brasil 'Itatiaia, L. Azul, E. do Rio\ Trav., Barth, Albuquerque \&\ Barros col. 26-ix1954'; Parátipos: mesma procedência (1 macho, 1 fêmea, MNRJ).

Material adicional examinado: Brasil. Paraná: Antonina, Reserva Biológica Sapitundava, 16.xi.1987, Levantamento Entomológico PROFAUPAR col.(1 fêmea, DZUP); Colombo, EMBRAPA, Br 476, Km 20, 27.x.1986, idem (1 macho, 1 fêmea, DZUP); idem, 3.xi.1986, mesmo col (1 macho, 1 fêmea, DZUP); idem, 22.xii.1986, mesmo col (1 fêmea, DZUP); idem, 2.iii.1987, idem (1 fêmea, DZUP); idem, 16.iii.1987, idem (1 fêmea, DZUP); Guarapuava, Estação Águas Santa Clara, 1.ix.1986, idem (2 fêmeas, DZUP); Ponta Grossa, Vila Velha, IAPAR, 27.ix.1999, Ganho \& Marinoni col. (1 fêmea, DZUP); São José dos Pinhais, Serra do Mar, Br 277, Km 54, 2.xi.1986, Levantamento Entomológico PROFAUPAR (1 macho, DZUP); Telêmaco Borba, Reserva Biológica Samuel Klabin, 21.ix.1987, idem (1 fêmea, DZUP).

Distribuição geográfica: Brasil: Rio de Janeiro, Paraná.

Fannia obscurinervis (Stein, 1900).

(Figs. 17, 28, 43, 77, 96, 112, 125, 140, 159, 178, 197, 216, 233, 248)

Diagnose: Dois pares de cerdas pré-escutelares desenvolvidas; asa castanha com margem superior e veias transversais orladas de castanho-escuro. Macho com cerdas frontais de 11 a 20 pares; fêmur posterior na face posterior sem cerdas diferenciadas. Fêmea inteiramente negra, cerdas frontais de dois a quatro pares fortes e quatro a cinco fracos.

Redescrição: Macho: Comprimento total 4,5-5,5 mm (N=5); asa 4,3-4,8 $\mathrm{mm}(\mathrm{N}=5)$. Holóptico. Olhos fracamente ciliados. Cerdas frontais em número de 11 a 20 pares (Fig. 28). Placa fronto-orbital, vita frontal, parafaciália, gena e face castanhoescuras a negras, podendo apresentar polinosidade prateada. Escapo e pedicelo negros. Flagelômero castanho-escuro com forte polinosidade cinza. Base da arista castanho-clara e ápice castanho-escuro. Palpo castanho-escuro e levemente clavado, com o ápice medindo cerca de 1,2 vez a largura da base. Tórax inteiramente castanho-escuro. Uma pré-alar. Dois pares de cerdas pré-escutelares desenvolvidas. Caliptras esbranquiçadas, amareladas ou castanhas, podendo apresentar as bordas amareladas ou acastanhadas. Halter castanho. Asa castanha com a margem superior e nervuras transversais castanho-escuras (Fig. 17). Pernas castanhoescuras e pulvilos amarelados. Fêmur anterior na face posteroventral com uma série de cerdas a partir da metade apical. Tíbia média na face posterior com duas cerdas medianas. Coxa posterior na face posterior com duas a três cerdas. Fêmur posterior na face anteroventral com três a quatro cerdas longas a partir do terço médio (Fig. 77). Face posterior sem cerdas diferenciadas (Fig. 96). Tíbia posterior na face anteroventral com uma a três cerdas. Abdome castanho-escuro a negro com polinosidade cinzenta (Fig. 112). Esternito I fortemente ciliado. Esternito V (Fig. 140). Terminália (Figs. 159, 178): epândrio mais largo que longo com cerdas curtas e mais densas na base; placa cercal desenvolvida coberta por cerdas curtas sendo que no ápice há cerdas diferenciadas das demais, as quais são mais longas; surstilos fusionados à placa cercal, alargados na base e afilados no ápice, processo baciliforme em forma de gancho. Hipândrio e estruturas associadas (Figs. 197, 216).

Fêmea similar ao macho, exceto: comprimento total 4,3-6,0 $\mathrm{mm}(\mathrm{N}=7)$; asa 4,0-5,2 mm ( $\mathrm{N}=10)$. Dicóptica. Cerdas frontais em número de dois a quatro pares de cerdas fortes e quatro a cinco pares mais fracos (Fig. 43). Cerdas orbital superior e inferior voltadas para a porção posterior da cabeça (Fig. 43). Placa fronto-orbital negra brilhante com uma série de cílios. Tíbia posterior na face anteroventral com três a quatro cerdas fracas. Abdome inteiramente negro sem polinosidade cinzenta (Fig. 125). Terminália (Fig. 233): cercos pouco mais longos que a placa anal e densamente cobertos por cerdas de diferentes tamanhos; placa anal quase tão larga quanto longa, densamente coberta por cerdas; esternito VIII reduzido em duas placas posteriores esclerotinizadas e duas placas anteriores circulares e membranosas; esternito VII quase tão longo quanto largo, de forma retangular; esternito VI mais largo que longo. Duas espermatecas fusiformes e rugosas (Fig. 248).

Comentários: F. obscurinervis pertence ao grupo obscurinervis (Albuquerque et al. (1981).

Albuquerque (1946) redescreveu detalhadamente $F$. obscurinervis apresentando figuras de asa, pernas anterior, média e posterior, terminália masculina e espermateca.

Primeiro registro para Santa Catarina e Rio Grande do Sul.

Biologia: Espécie sinantrópica (Oliveira 1986; Carvalho et al. 2002), sendo encontrada em maior densidade na zona rural (Almeida et al. 1985).

F. obscurinervis pode ser coletada em armadilhas com iscas de vísceras de galinha e fezes humunas (Linhares 1981), sardinha fresca, figado cru de galinha, e cebola em decomposição (Almeida et al. 1985), rato em decomposição (Linhares 1981; Moura et al. 1997), e em camarão e banana em decomposição (dados de etiqueta).

Esta espécie pode ter importância na entomologia forense, pois pode estar associada à decomposição de animais (Linhares 1981; Moura et al. 1997, 1998).

Material-tipo (não examinado). Síntipos macho e fêmea destruídos (Carvalho et al. 2003)

Material examinado: Brasil. São Paulo: Barueri, 8.i.1966, K. Lenko col. (1 macho, DZUP); Engenheiro Lefevre, Campos do Jordão, 1200 m, 28.ix.1962, L. T. F. Papavero, Rabello, L. Silva \& Zanettin col. (1 fêmea, DZUP); idem, 24.i.1963, J. Guimarães, Medeiros, L. Silva, A. Rocha \& L. T. F. Papavero col. (1 fêmea, DZUP); Paraná: Almirante Tamandaré, Córrego Fundo, 2.vii.1991, M. O. Moura col. (9 fêmeas, DZUP); Castro, 21.xii.1965, Laroca col. (1 fêmea, DZUP); Curitiba, 


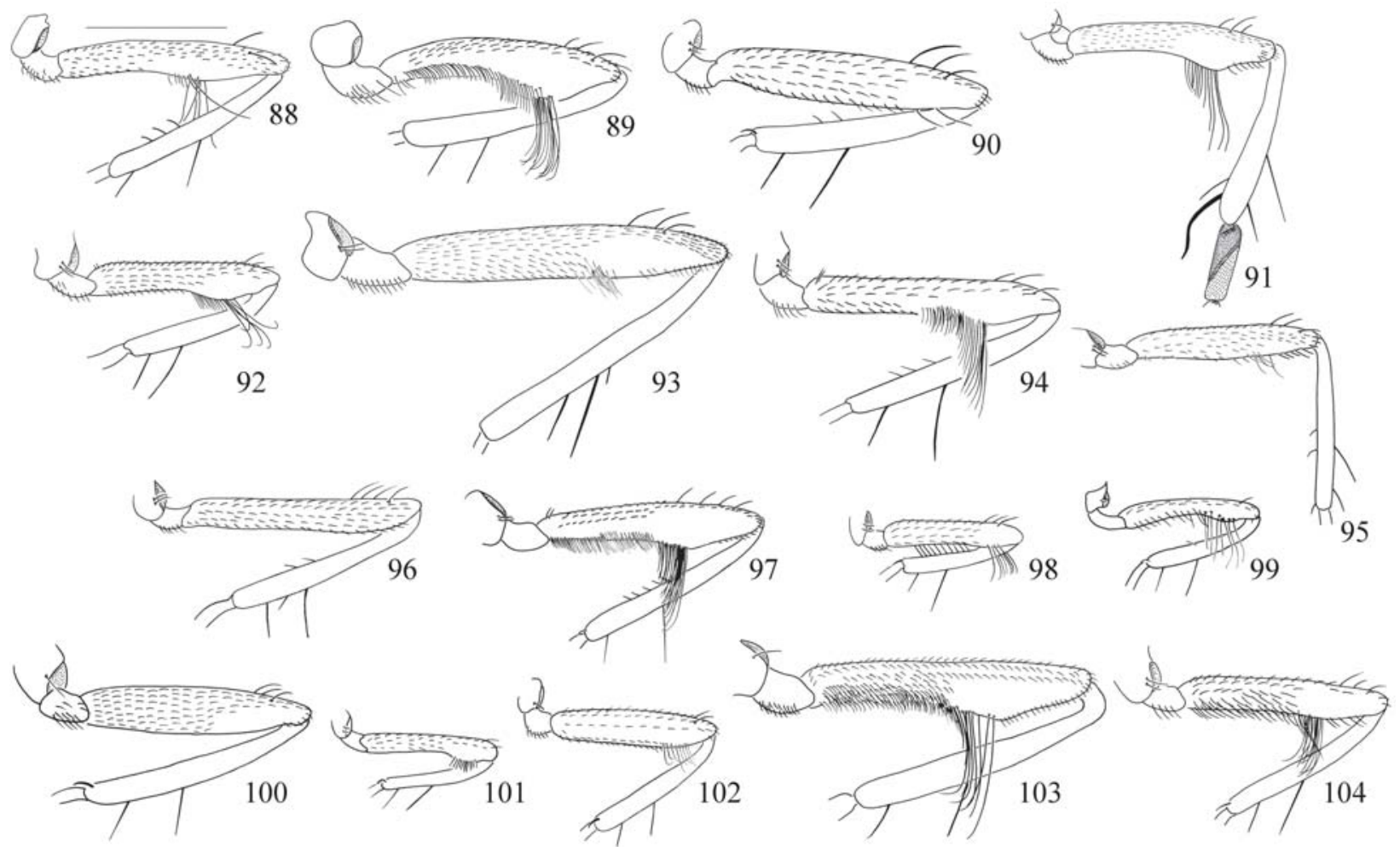

Figs. 88-104. Perna posterior, vista posterior, macho: 88, F. admirabilis; 89, F. albitarsis; 90, F. canicularis; 91, F. carvalhoi; 92, F. femoralis; 93, F. flavicincta; 94, F. heydenii; 95, F. itatiaiensis; 96, F. obscurinervis; 97, F. penicillaris; 98, F. pusio; 99, F. sabroskyi; 100, F. scalaris; 101, F. snyderi; 102, F. trimaculata; 103, F. tumidifemur; 104, F. yenhedi. Escala: $1 \mathrm{~mm}$.

18.i.1984, M. L. Pilloto \& A. C. Saad col. (2 fêmeas, DZUP); idem, 19.xi.1982, R. Misiuta col. (1 fêmea, DZUP); idem, 26.xi.1984, R Zonta \& M. Santos col. (4 machos, 24 fêmeas, DZUP); Curitiba, Capão da Imbuia, 12.ii.1985, S. R. Walkowski col. (1 fêmea, DZUP); idem, 13.ii.1985, idem (4 fêmeas, DZUP); idem, 6.iii.1985, idem (1 fêmea, DZUP); idem, 7.iii.1985, idem (3 fêmeas, DZUP); idem, 8.iii.1985, idem (1 fêmea, DZUP); idem, 14.iii.1985, idem (1 fêmea, DZUP); idem, 15.iii.1985, idem (1 fêmea, DZUP); Curitiba, Parque Iguaçu, 6.x.1993, I. M. de M. Lima col. (1 fêmea, DZUP); Curitiba, 45.xii.1999, R. K. Yamasaki col. (2 machos, 7 fêmeas, DZUP); Curitiba, Uberaba, 27.i [sem ano], D. takaki col. (1 fêmea, DZUP); idem, 6.xi [sem ano], idem (2 fêmeas, DZUP); idem, 12.xi. [sem ano], idem (1 fêmea, DZUP); Foz do Iguaçu, 15.xii.1965, V. Grat \& L. Azevedo col. (2 fêmeas, DZUP); idem, 3.xii.1966, Exc. Departamento de Zoologia col. (1 macho, DZUP); idem, 15.ix.1969, E. Cichovski col. (1 fêmea, DZUP); Estrada do Cerne, Km 11, 18.ii.1976, A. Imbiriba col. (1 macho, DZUP); Fênix, Reserva Estadual, ITCF, 2.x.1986, Levantamento Entomológico PROFAUPAR col. (1 macho, DZUP); Iguaçú, xii. 1941, Com. E. N. V. col (1 macho, 4 fêmea, MNRJ); Londrina, 12.x.1982, O. C. Milke col (4 machos , 2 fêmeas, DZUP); Pinhão, Salto Segredo, 19.i.1992, R. Misiuta col. (3 fêmeas, DZUP); Piraquara, 5.iv.1974, J. Ferreira col. (4 fêmeas, DZUP); idem, 9.v.1974, idem (3 fêmeas, DZUP); idem, 10.v.1974, idem (5 fêmeas, DZUP); idem, 11.v.1974, idem (3 fêmeas, DZUP); idem, 12.v.1974, idem (1 fêmea, DZUP); idem, 13.v.1974, idem (10 fêmeas, DZUP); idem, 920.ii.2003, A. J. C. Aguiar col. (1 macho, 2 fêmeas, DZUP); Telêmaco Borba, Reserva Biológica Samuel Klabin, 11.vii.1987, Levantamento Entomológico PROFAUPAR col. (1 fêmea, DZUP); idem, 24.vii.1987, idem (1 macho, 2 fêmeas, DZUP); idem, 3.viii.1987, mesmo col (2 machos, 1 fêmea, MZSP); idem, 24.viii.1987, idem (1 macho, DZUP); idem, 31.viii.1987, idem (1 macho, 3 fêmeas, DZUP); idem, 7.ix.1987, (1 fêmea, DZUP); idem, 14.ix.1987, idem (2 machos, 1 fêmea, DZUP); idem, 5.x.1987, idem (1 fêmea, DZUP); idem, 19.x.1987, idem (1 fêmea, DZUP); idem, 16.xi.1987, idem (1 fêmea, DZUP); Terra boa, 1-3.i.1985, J. A. Rafael col. (1 fêmea, DZUP); Santa Catarina: Nova Teotônia, v.1967, F. Plaumann col. (1 fêmea, DZUP); idem, viii.1967, idem (2 fêmeas, DZUP); idem, ix.1967, idem (1 fêmea, DZUP); idem, v.1970, idem (1 macho, 1 fêmea, MZSP); idem, vi.1970, idem (2 fêmeas, MZSP); idem, vii.1970, idem (1 macho, 1 fêmeas, MZSP); idem, iv.1971, idem (2 fêmeas, MZSP); idem, vii.1971, idem (1 macho, MZSP); idem, ix.1971, idem (1 fêmea, MZSP); idem, x.1971, mesmo col (2 machos, 2 fêmeas, MZSP); idem, xi.1971, idem (3 machos, 5 fêmeas, MZSP); Rio Grande do Sul: Arroio Grande, Mauá, 30.viii.2002, R. F. Krüger col. (1 fêmea, DZUP); Capão do Leão, Barragem da Eclusa, 12.vii.2002, idem (1 fêmea, DZUP); Pelotas, Laranjal, 12.vii.2002, idem (2 fêmeas, DZUP); Pelotas, $31^{\circ} 44^{\prime} 39^{\prime \prime} \mathrm{S} 52^{\circ} 13^{\prime} 22^{\prime \prime} \mathrm{W}$, 17.i.2003, idem (1 fêmea, DZUP)

Distribuição geográfica: México, Venezuela, Guiana, Colombia, Peru, Bolívia, Paraguai e Brasil (Carvalho et al. 2003).

Brasil: Amazonas, Roraima, Pernambuco, Bahia, Espírito Santo, Goiás, Minas Gerais, Mato Grosso, Mato Grosso do Sul, Rio de Janeiro, São Paulo, Paraná, Santa Catarina, Rio Grande do Sul.

\section{Fannia opsia sp. nov.}

(Figs. 8, 11, 12, 18, 78, 113, 141, 160, 179, 198, 217)

Diagnose: Coloração geral negra, halter castanho e fêmur posterior na face posterior com fraco conjunto de cerdas diferenciadas.

Descrição: Holótipo macho: comprimento total de 4,8 mm; comprimento da asa 4,6 mm. Holóptico. 
Cabeça (Fig. 8): Olhos com cílios fracos, curtos e esparsos. Espaço interocular cerca de 0,12 vezes a largura da cabeça ao nível do ocelo anterior. Cerdas frontais em número de 16 pares. Triângulo ocelar com dois pares de cerdas, o anterior longo, atingindo o segundo par de cerdas frontais. Placa frontoorbital, vita frontal, parafaciália, gena e face negras. Escapo, pedicelo e arista negros. Flagelômero coberto com densa polinosidade acinzentada. Flagelômero mede cerca de duas vezes o tamanho do pedicelo. Arista com cílios bastante curtos. Palpo castanho-escuro e filiforme, com o ápice de mesma largura da base.

Tórax: Inteiramente castanho-escuro (Fig. 12). Cerdas acrosticais pré-suturais em duas e três séries desordenadas e pós-suturais em três e quatro séries desordenadas, terminadas em dois pares de cerdas pré-escutelares desenvolvidas. Cerdas dorsocentrais 2:3. Duas cerdas umerais, a interna menor. Uma cerda pós-umeral e uma pré-sutural maior. Duas cerdas notopleurais. Uma cerda pré-alar pequena, indistinta dos cílios de fundo. Uma cerda supra-alar. Duas cerdas intra-alares e duas pós-supra-alares. Escutelo castanho-escuro. Um par de cerdas escutelares basais e um par de apicais desenvolvidas, um par de laterais e um par de pré-apicais menores. Caliptras esbranquiçadas. Caliptra inferior cerca de 0,5 vezes o tamanho da superior. Halter castanho-escuro. Asa acastanhada (Fig. 18).

Pernas: Inteiramente castanho-escuras (Fig. 8). Pulvilos pequenos e castanhos (Fig. 8). Fêmur anterior nas faces posterodorsal e posteroventral com uma série completa de cerdas; face posterior com três séries completas de cerdas longas e finas. Tíbia anterior na face dorsal com uma cerda forte pré-apical; faces ventral e posteroventral com uma cerda apical fraca. Fêmur médio na face posterior com série de cerdas finas e de ápice curvo e a partir do terço apical são fortes e de ápice truncado; faces anteroventral e posteroventral com uma série completa de cerdas fortes que diminuem de tamanho a partir do terço apical; face anterodorsal pré-apicalmente com quatro cerdas longas e curvas. Tíbia média na face ventral pubescente e constrita até a metade basal; face anterodorsal com uma cerda no terço apical e uma pré-apical forte; face anterior com uma cerda apical; face posterior com uma cerda no terço apical e uma apical; faces ventral e posteroventral com uma cerda apical. Coxa posterior na face posterior com dois cílios. Fêmur posterior na face posterior com séries de cerdas finas que pré-apicalmente formam um fraco conjunto mais denso de cerdas, contudo, sem formar um tufo (Fig. 11); face anterior com uma série de cerdas (Fig. 78), sendo as seis apicais maiores; face anterodorsal com quatro cerdas préapicais dirigindo-se para a face dorsal. Tíbia posterior na face dorsal nas porções média e pré-apical com uma cerda; face anteroventral com duas cerdas medianas e uma apical mais forte (Fig. 78); face anterodorsal com uma cerda mediana e uma pré-apical.

Abdome: Inteiramente castanho escuro (Fig. 113). Esternito I densamente ciliado. Esternito V (Fig. 141). Terminália (Figs. 160, 179): epândrio pouco mais longo que largo com cerdas até a metade basal de diferentes tamanhos; placa cercal pouco desenvolvida, fortemente afilada na margem posterior e coberta por cerdas curtas e uniformes; surstilos alargados na base e fortemente afilado na base; processo baciliforme fusionado ao epândrio, rugoso com densos espinhos em sua superfície. Hipândrio e estruturas associadas (Figs. 198, 217).

Fêmea desconhecida.

Variação: o número de cerdas frontais varia de 16 a 18 pares, e alguns exemplares podem apresentar caliptras castanhas.

Comentários: Fannia opsia sp nov. é similar a $F$. obscurinervis, devido ao padrão de coloração do corpo, contudo, difere por apresentar no fêmur posterior na face posterior um fraco conjunto de cerdas pré-apicais. A terminália de $F$. opsia sp. nov. é bastante singular, principalmente na forma do processo baciliforme, o qual é pontiagudo, rugoso e fusionado à base do epândrio.

Não foi possível alocar $F$. opsia sp. nov. nos grupos apresentados por Chillcott (1961) e Albuquerque (1981). Apesar de $F$. opsia sp. nov. ser bastante similar à $F$. obscurinervis quanto à morfologia externa, não foi exequível afirmar sua inclusão no grupo obscurinervis, principalmente pela sua grande diferença na terminália e pelo desconhecimento da fêmea.

O holótipo encontra-se em ótimo estado, alfinetado, apresentando todas as estruturas, exceto o abdome, no qual foi retirado para a observação e confecção das ilustrações da terminália, sendo posteriomente armazenado em microtúbulos plásticos com glicerina e aficçado ao alfinete do respectivo exemplar.

Material-tipo: Holótipo macho (DZUP): Brasil. Paraná 'Ponta Grossa PR Brasil $($ Vila Velha-IAPAR)\Ganho \& Marinoni\ 28-VIII2000 MALAISE 4'.

Parátipos: 'Brasil PR Jundiaí do Sul\ Fazenda Monte Verdel 15.VIII.1988\Lev. Ent. PROFAUPAR MALAISE' (1 macho, DZUP); 'P. Grossa (Vila Velha) PR\ Reserva IAPAR Br 376\ Brasil 11.VIII.1986। Lev. Ent. PROFAUPAR $\backslash$ MALAISE' (1 macho, DZUP); 'Ponta grossa, PR, Brasil\ (V. Velha- IAPAR)\ Ganho \& Marinoni\ 13.IX.1999 MALAISE 4' (1 macho, DZUP); mesmos dados, exceto '08-V-2000' (1 macho, DZUP); mesmos dados, exceto '24-VI-2000' (1 macho, DZUP); mesmos dados, exceto '28-VIII-2000' (1 macho, DZUP); mesmos dados, exceto '31-VII-2000' (2 machos, DZUP).

Distribuição geográfica: Brasil: Paraná.

Etimologia: O epíteto específico refere-se à coloração negra do corpo (grego - opsia $=$ noite $)$.

\section{Fannia penicillaris (Stein, 1900)}

(Figs. 19, 29, 55, 79, 97, 114, 142, 161, 180, 199, 218)

Diagnose: Cerdas frontais em número de dez a 19 pares, escuto castanho-escuro até o segundo par de cerdas dorsocentrais pós-suturais e castanho-claro até o ápice do escutelo, fêmur posterior nas faces ventral e posteroventral com uma forte protuberância pré-apical, na qual se inserem um conjunto de cerdas longas e de ápice curvo, formando um tufo. 

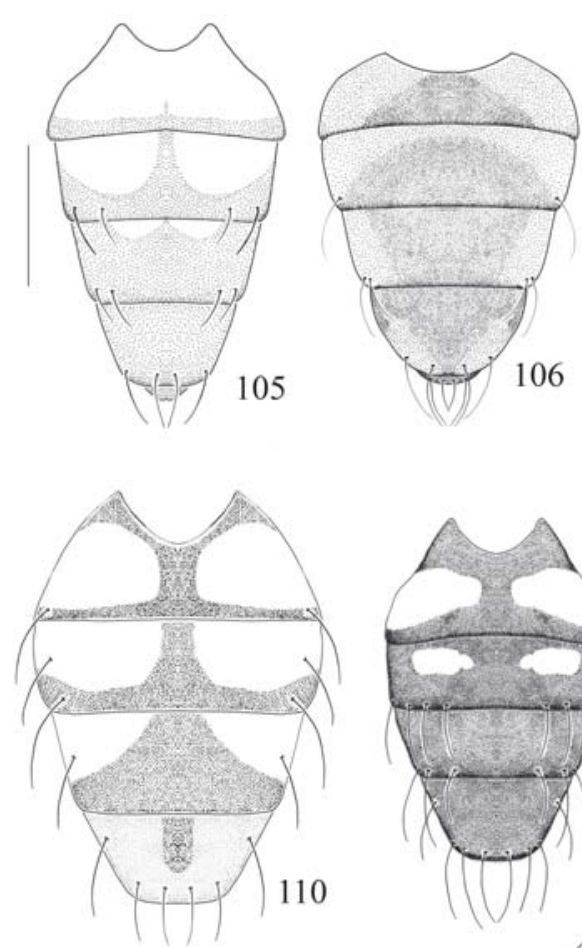

110

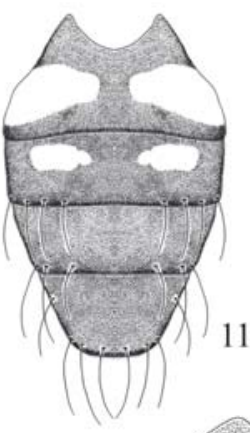

111
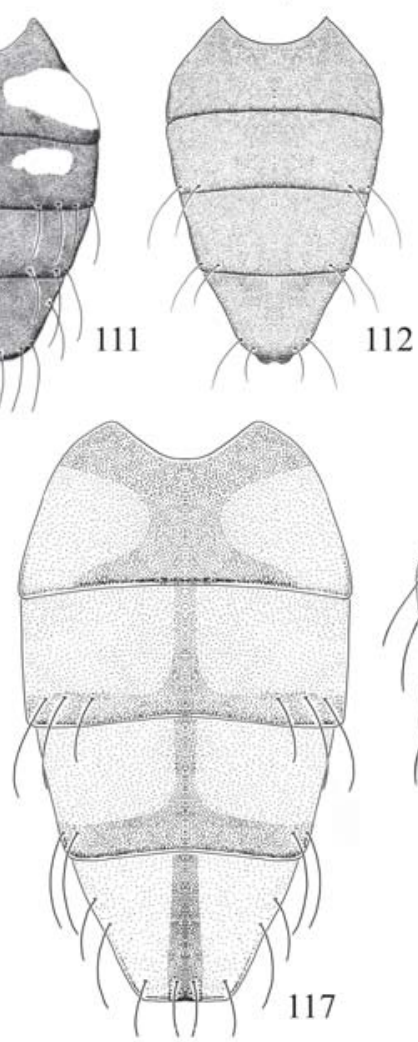
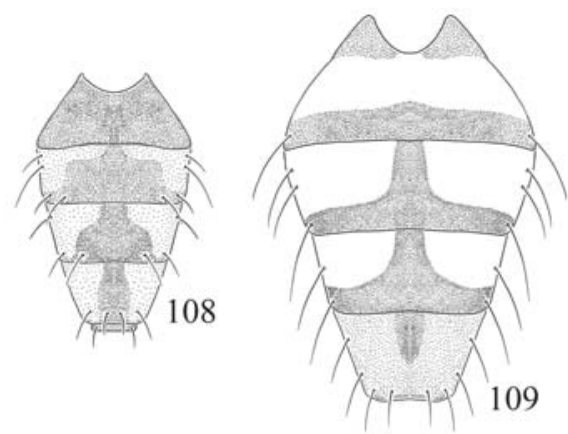

107
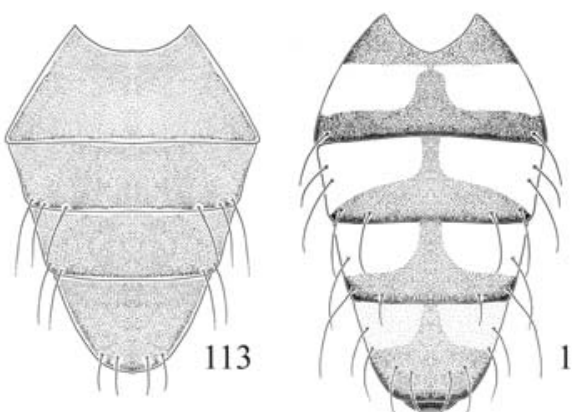

114

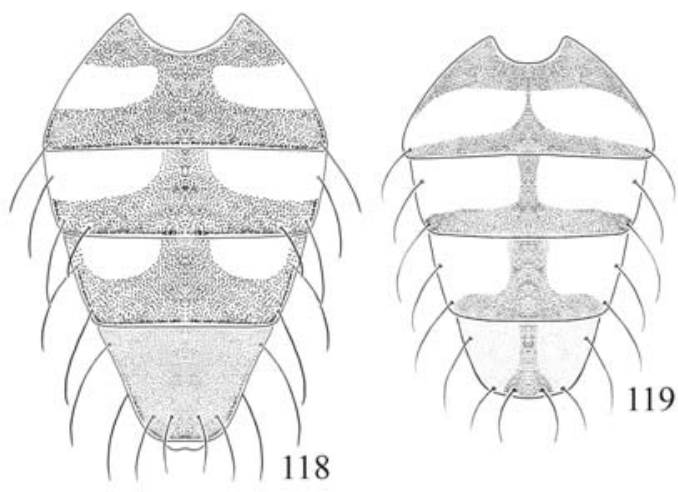

115
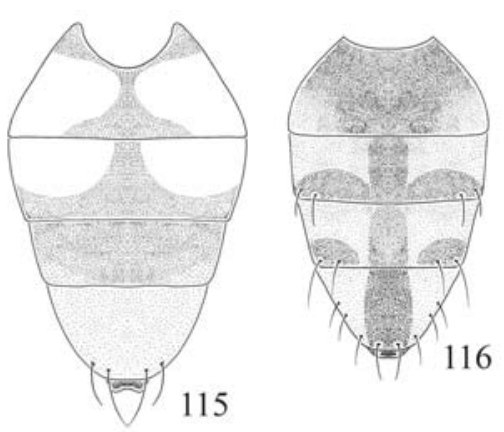

Figs. 105-119. Abdome, vista dorsal, macho: 105, F. admirabilis; 106, F. albitarsis; 107, F. canicularis; 108, F. carvalhoi; 109, F. flavicincta; 110, F. heydenii; 111, F. itatiaiensis; 112, F. obscurinervis; 113, F. opsia sp. nov.; 114, F. penicillaris; 115, F. pulvinilenis; 116, F. pusio; 117, F. scalaris; 118, F. tumidifemur; 119, F. yenhedi. Escala: $1 \mathrm{~mm}$.

Redescrição: Macho: Comprimento total de 5,5-7,5 mm $(\mathrm{N}=7)$; asa 5,3-7,0 $\mathrm{mm}(\mathrm{N}=7)$. Holóptico. Olhos nus. Cerdas frontais em número de dez a 19 pares (Fig. 29). Vita frontal negra. Placa fronto-orbital, parafaciália, gena e face cobertos com forte polinosidade prateada. Escapo, base do pedicelo e ápice da arista castanho-escuros. Ápice do pedicelo e base da arista castanho-claros. Flagelômero coberto com densa polinosidade cinzenta. Arista com fraca pubescência. Palpo castanho-escuro e clavado, com o ápice medindo cerca de duas vezes a largura da base. Escuto castanho-escuro até o segundo par de cerdas dorsocentrais pós-suturais e castanhoclaro até o ápice do escutelo (Fig. 55). Escutelo castanho- claro, podendo apresentar o ápice acinzentado. Pleuras acinzentadas. Uma pré-alar. Caliptras esbranquiçadas, podendo apresentar os bordos amarelados ou acastanhados. Halter amarelado. Asa com a margem superior acastanhada (Fig. 19). Pernas castanho-escuras e pulvilos branco-amarelados. Fêmur anterior na face posteroventral com uma série de cerdas a partir do terço apical. Tíbia média na face posterior com uma cerda mediana. Coxa posterior na face posterior com uma a três cerdas. Fêmur posterior nas faces ventral e posteroventral com uma forte protuberância pré-apical, na qual se inserem um forte conjunto de cerdas longas e de ápice curvo, formando um tufo (Fig. 97). Tíbia posterior na face anteroventral com 
quatro a cinco cerdas (Fig. 79). Abdome alongado com tergitos I-IV lateralmente amarelo-translúcidos e com uma listra mediana castanho-escura, tergito V castanho acinzentado (Fig. 114). Esternito I ciliado. Esternito V (Fig. 142). Terminália (Figs. 161, 180): padrão do grupo heydenii (ver redescrição de $F$. flavicincta). Hipândrio e estruturas associadas (Figs. 199, 218).

Comentários: $F$. penicillaris pertence ao grupo heydenii (Albuquerque et al. 1981). O macho é similar ao macho de $F$. tumidifemur, contudo, difere principalmente pela coloração característica do escuto castanho-escura até a segunda cerda dorsocentral pós-sutural.

Não foi possivel identificar e descrever a fêmea de $F$. penicillaris devido a sua grande similaridade com $F$. tumidifemur. As descrições originais (Stein 1911) e as redescrições (Albuquerque 1957b; Albuquerque et al. 1981) foram pouco informativas. Além disso, não foi possível observar a série-tipo de ambas as espécies e, também não foi exequível a separação das espécies pelos dados de localidade, por estas ocorrerem simpatricamente. Por estes motivos foi optado não assumir alguma posição em relação à identificação das fêmeas de $F$. penicillaris e $F$. tumidifemur.

Primeiro registro para Santa Catarina e Rio Grande do Sul.

Biologia: Fannia penicillaris apresenta hábito sinantrópico (Almeida et al. 1985; Carvalho et al. 2002) e importância médico veterinária por ser vetora de ovos de D. hominis (Guimarãe \& Papavero 1999).

Os adultos podem ser coletados em cebola em decomposição, figado de galinha e sardinha (Almeida et al. 1985; Leandro \& D'Almeida 2005), além de armadilha luminosa, armadilhas com banana em decomposição e carne (dados de etiquetas dos espécimes observados).

Material-tipo (não examinado). Síntipos macho e fêmea depositados no Museum für Naturkunde der Humboldt-Universität, ou encontramse destruídos (Carvalho et al. 2003).

Material examinado: Brasil. São Paulo: Campinas, Mata de Santa Genebra, 27.iii.1997, A. X. Linhares Col. (1 macho , DZUP); Paraná: Antonina, Reserva sapitanduva, 4.viii.1986, Levantamento Entomológico PROFAUPAR col. (2 machos, ZDUP); idem, 11.viii.1987, idem (1 macho, DZUP); Colombo, Mata da EMBRAPA, 22.i.1992, C. J. B. de Carvalho col. (1 macho, DZUP); idem, mesmo data, M. Marques, L. Batista \& M. Moura col. (1 macho, DZUP); Curitiba, 14.iii.1981, C. B. Jesus col. (1 macho, DZUP); Curitiba, Capão da Imbuia, 13.ii.1985, A. F. Yamamoto col. (1 macho, DZUP); Curitiba, S. Laroca col. (2 machos, DZUP); Guarapuava, Estação Águas Santa Clara, 18.viii.1986, Levantamento Entomológico PROFAUPAR col. (1 macho, DZUP); idem, 15.ix.1986, idem (1 macho, DZUP); Londrina, 12.i.1982, H. Milke col. (2 machos, DZUP); Guaratuba, Alto da Serra, Km 64, Morretes, IAPAR, 10-17.ix.1984, C.I.F.F. col. (1 macho, DZUP); memo local, 28-29.ii.1985, idem (1 macho, DZUP); idem, 3.iv.1985, idem (1 macho, DZUP); idem, 4.iv.1985, idem (1 macho, DZUP); 1-8.x.1985, idem (1 macho, DZUP); Pinhão, 15.i.1992, R. Misiuta col. (16 machos, DZUP); Piraquara, 9-20.ii.2003, A. J. C. Aguiar col. (1 macho, DZUP); Tijucas do Sul, Vossoroca, 27.viii.1982, J. Delome col. (4 machos, DZUP); Telêmaco Borba, Reserva Samuel Klabin, 3.xi.1986, Levantamento Entomológico PROFAUPAR col. (1 macho, DZUP); idem, 7.ix.1987, idem (1 macho, DZUP); idem, 12.x.1987, idem (1 macho, DZUP); Santa Catarina: Nova Teotônia, ii. 1966, F. Plaumann col. (1 macho, MZSP); idem, vi.1970, idem (1 maho, MZSP); idem, x.1970, idem (2 machos, MZSP); idem, xi.1970, idem (2 machos, MZSP); idem, ii.1971, idem (2 machos, MZSP); idem, iii.1971, idem (1 macho, MZSP); Rio Grande do Sul: Pelotas, 15.ix.1959, C. Bierauk col. (1 macho, MZSP).

Distribuição geográfica: Colômbia, Peru, Bolívia e Brasil (Carvalho et al. 2003).

Brasil: Minas Gerais, Rio de Janeiro, São Paulo, Paraná, Santa Catarina, Rio Grande do Sul.

Fannia pulvinilenis sp. nov.

(Figs. 9, 13, 15, 80, 115, 143, 162, 181, 200, 219)

Diagnose: Cerdas frontais em número de nove pares de diferentes tamanhos, escuto castanho-claro com reflexos dourados, apresentando, não muito nítidas, três listras castanhas até a base do escutelo, fêmur posterior nas faces ventral e posteroventral nu apicalmente e tarsômeros com reflexos dourados, levemente dilatados e pulvilos desenvolvidos

Descrição: Holótipo macho: comprimento total de 5,0 mm; comprimento da asa: 4,6 mm. Holóptico.

Cabeça (Fig 9): olhos nus. Espaço interocular 0,3 vezes a largura da cabeça ao nível do ocelo anterior. Cerdas frontais em número de nove pares de diferentes tamanhos. Triângulo ocelar com dois pares de cerdas, o anterior mais forte. Vita frontal, negra. Placa fronto-orbital, parafaciália, gena e face com forte polinosidade prateada. Escapo, pedicelo e ápice da arista castanhos. Base da arista castanho-clara. Flagelômero negro coberto com forte polinosidade acinzentada, e cerca de 2,6 vezes o tamanho do pedicelo. Arista com cílios bastante curtos. Palpo castanho-escuro e clavado, com o ápice medindo cerca de 1,5 vezes a largura da base.

Tórax: Escuto castanho-claro com reflexos dourados (Fig. 13), apresentando, não muito nítidas, três listras castanhas até a base do escutelo. Pleura acinzentada (Fig. 13). Cerdas acrosticais pré-suturais em duas e três séries desordenadas e pós-suturais em três e quatro séries desordenadas, terminadas em um par de cerdas pré-escutelares desenvolvidas. Cerdas dorsocentrais 2:3. Duas cerdas umerais, a interna menor. Uma cerda pós-umeral, e uma cerda pré-sutural. Duas cerdas notopleurais. Uma cerda pré-alar pequena. Uma cerda supraalar. Duas cerdas intra-alares e duas pós-supra-alares. Um par de cerdas escutelares basais e um par de apicais desenvolvidas, um par de laterais e um par de pré-apicais menores. Caliptras e halter amarelados. Caliptras inferior e superior de mesmo tamanho. Asa amarelada.

Pernas: Coxas, trocânteres e fêmures enegrecidos (Fig. 13). Tíbias castanho-escuras. Tarsômeros com reflexos dourados e levemente dilatados dorsoventralmente (Fig. 15). Pulvilos amarelados e desenvolvidos (Fig. 15). Fêmur anterior nas faces posterodorsal e posteroventral com uma série completa de cerdas fortes; face posterior com duas séries completas de cerdas fracas. Tíbia anterior na face dorsal com uma cerda forte pré-apical; faces ventral e posteroventral com uma cerda apical. Fêmur médio na face anteroventral e ventral com uma série completa de cerdas fortes que diminuem de tamanho 

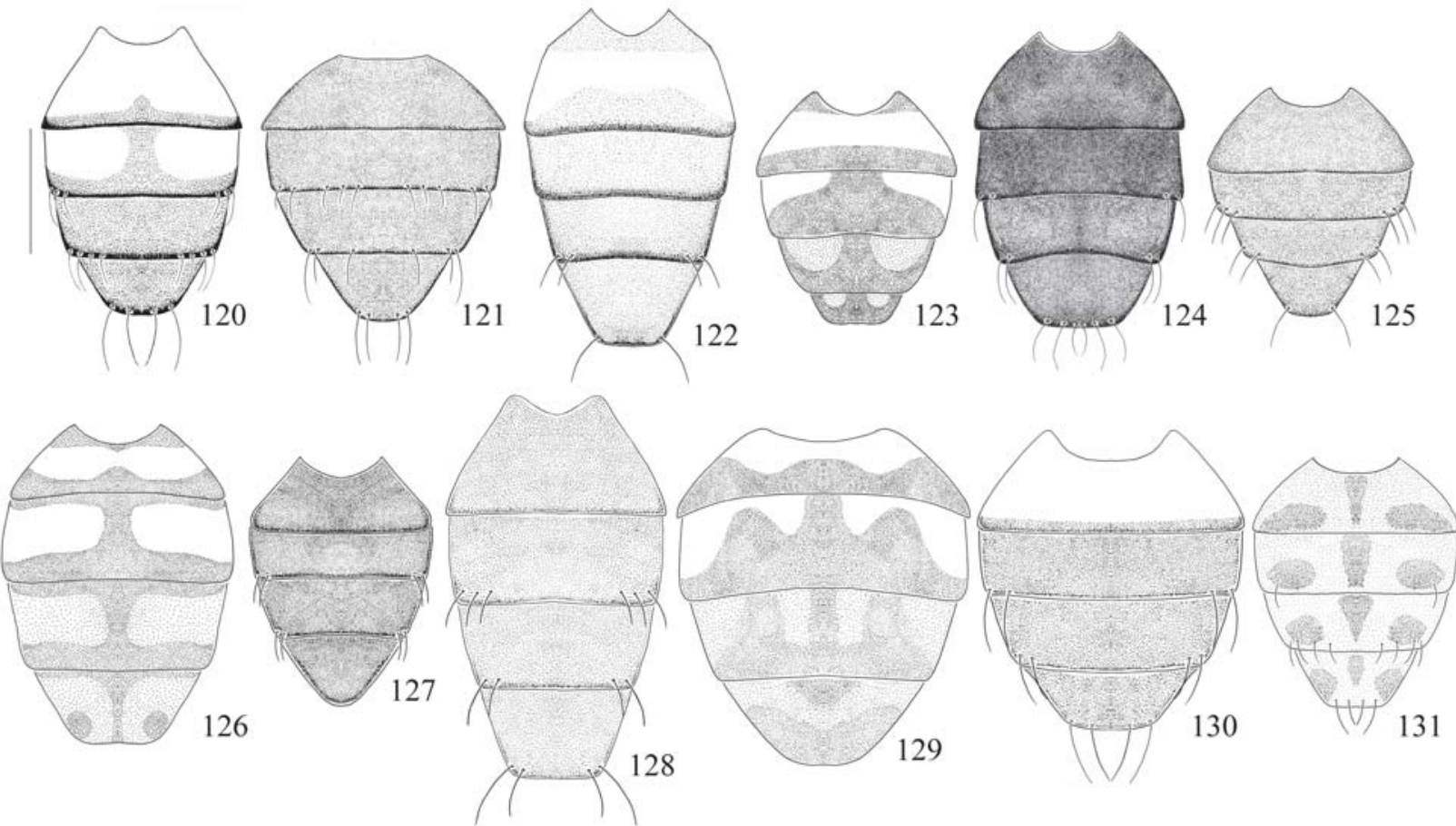

Figs. 120-131. Abdome, vista dorsal, fêmea: 120, F. admirabilis; 121, F. albitarsis; 122, F. canicularis; 123, F. flavicincta; 124, F. itatiaiensis; 125, F. obscurinervis; 126, F. punctipennis; 127, F. pusio; 128, F. scalaris; 129, F. xanthocera; 130, F. xanthothrichia sp nov.; 131, F. yenhedi. Escala: $1 \mathrm{~mm}$.

apicalmente; face posterior com uma série completa de cerdas, as quais as cinco apicais são maiores e curvas. Tíbia média na face ventral constrita na metade basal e com forte pubescência; face dorsal com uma cerda no terço apical e uma pré-apical; faces anterior e anteroventral com uma cerda apical forte; face posterior com uma cerda mediana e uma apical. Coxa posterior na face posterior com uma cerda. Fêmur posterior na face ventral e posteroventral nua apicalmente; face anteroventral com cinco cerdas a partir da metade apical, de diferentes tamanhos; face anterodorsal com seis cerdas a partir do terço apical, as quais se dirigem para a face dorsal (Fig. 80). Tíbia posterior na face dorsal na porção média e pré-apical com uma cerda; face anterodorsal no terço apical com uma cerda; face anteroventral com três cerdas medianas (Fig. 80).

Abdome: Tergitos I-III amarelos translúcidos, tergitos IV$\mathrm{V}$ acinzentados. Todos os tergitos apresentam uma listra longitudinal mediana negra (Fig. 115). Esternito I densamente ciliado. Quinto esternito (Fig. 143). Terminália (Figs. 162, 181): epândrio mais largo que longo coberto por cerdas até a metade basal; placa cercal desenvolvida, bilobada tanto na porção anterior quanto na posterior, apresentando uma forma de " $\mathrm{H}$ ", coberta uniformemente por cerdas longas e sinuosas; surstilos irregulares com forte tufo de cerdas na porção basal e interna, com uma projeção mediana e afilado no ápice; processo baciliforme curvo, com forma de vírgula. Hipândrio e estruturas associadas (Figs. 200, 219).

Variação: o número de cerdas frontais pode variar de nove a dez pares; alguns exemplares apresentaram o escuto uniformemente com reflexo dourado, não apresentando listras, e tíbia posterior na face anteroventral com três cerdas.

Comentários: Devido a forma da terminália de F. pulvinilenis sp. nov. ser bastante diferente das demais espécies de Fannia, não foi possível incluí-la nos grupos propostos por Chillcott (1961) e Albuquerque et al. (1981).

Os espécimes foram coletados em armadilha Malaise.

O holótipo encontra-se em ótimo estado, apresentando todas as estruturas.

Fêmea desconhecida.

Materiral-tipo examinado: Holótipo macho (DZUP): 'Brasil. RS

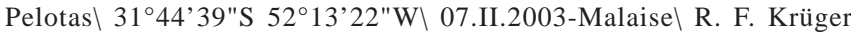
leg'. Parátipos (DZUP): mesma etiqueta do holótipo (2 machos).

\section{Distribuição geográfica: Brasil: Rio Grande do Sul.}

Etimologia: O epíteto específico refere-se ao pulvilo bastante desenvolvido e de aspecto almofadado (latim pulvinus $=$ almofada; lenis $=$ macio $)$.

\section{Fannia punctipennis Albuquerque, 1954}

(Figs. 20, 44, 60, 126, 234, 249)

Diagnose: Cerdas frontais em número de dez pares, escuto cinza-acastanhado com três listras castanho-claras, as quais se estendem até a base do escutelo, asa hialina com veias transversais com manchas castanho-escuras e fêmur posterior 


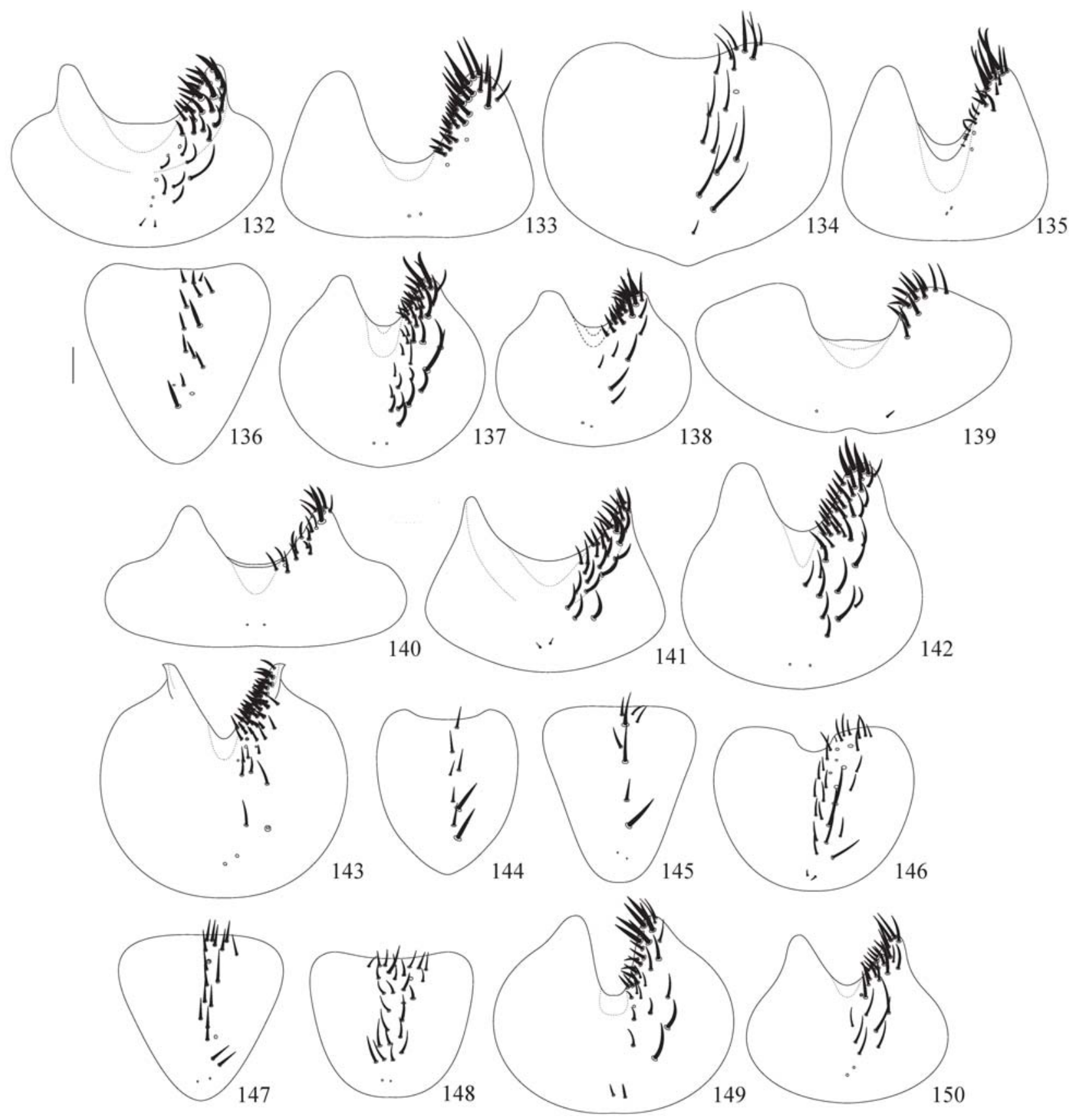

Figs. 132-150. Esternito V, vista ventral, macho: 132, F. admirabilis; 133, F. albitarsis; 134, F. canicularis; 135, F. carvalhoi; 136, F. femoralis; 137, F. flavicincta; 138, F. heydenii; 139, F. itatiaiensis; 140, F. obscurinervis; 141, F. opsia sp. nov.; 142, F. penicillaris; 143, F. pulvinilenis; 144, F. pusio; 145, F. sabroskyi; 146, F. scalaris; 147, F. snyderi; 148, F. trimaculata; 149, F. tumidifemur; 150, F. yenhedi. Escala: 0,1 mm.

na face posteroventral com uma leve protuberância pré-apical onde insere-se um forte tufo cerdas longas e de ápice curvo.

Redescrição: Macho: Comprimento total 5,0 mm (N=1); asa $4,7 \mathrm{~mm}(\mathrm{~N}=1)$. Holóptico. Olhos nus. Cerdas frontais em número de dez pares. Escapo, pedicelo, flagelômero e arista castanhoescuros. Vita frontal negra. Placa fronto-orbital, parafaciália, gena e face com polinosidade cinzenta. Palpo castanho-escuro e clavado, com o ápice medindo cerca de 1,5 vezes a largura da base. Escuto cinza-acastanhado com três listras castanho- claras, as quais se estendem até a base do escutelo. Uma préalar. Caliptras e halter amarelados. Asa hialina com as nervuras transversais, principalmente a $\mathrm{r}-\mathrm{m}$, fortemente orladas de castanho (Fig. 20). Pernas castanho-escuras. Tíbia média na face posterior com uma cerda submediana. Coxa posterior na face posterior ciliada. Fêmur posterior na face posteroventral com uma leve protuberância pré-apical onde insere-se um forte conjunto de cerdas longas e de ápice curvo, formando um tufo (Albuquerque 1954: figs. 6-7). Tíbia posterior na face ventral com três a quatro cerdas medianas. Abdome com 
tergitos I-IV lateralmente amarelo-translúcidos e com uma listra mediana castanho-escura, tergito $\mathrm{V}$ castanho acinzentado. Esternito I nu. Terminália (Albuquerque 1954, figs 9-14).

Fêmea semelhante ao macho, exceto: comprimento total 4,8-5,0 mm (N=5); asa 4,2-4,6 mm (N=5). Dicóptica. Cerdas frontais em número de oito pares de diferentes tamanhos (Fig. 44). Placa fronto-orbital com uma série de cílios. Cerda orbital inferior voltada para a porção posterior da cabeça. Escuto cinza-acastanhado com três listras castanho-claras, as quais se estendem até a base do escutelo (Fig. 60). Tíbia média na face ventral com uma a duas cerdas no terço apical. Fêmur posterior na face posteroventral nua e sem protuberância. Abdome castanho com tergitos I-III amarelados lateralmente e tergitos IV-V com manchas acinzentadas (Fig. 126). Terminália (Fig. 234): padrão do grupo heydenii (ver redescrição de $F$. flavicincta). Duas espermatecas rugosas (Fig. 249).

Comentários: F. punctipennis pertence ao grupo heydenii (Albuquerque et al. 1981).

Primeiro registro para Santa Catarina.

Biologia: F. punctipennis apresenta hábito sinantrópico, podendo apresentar alta densidade em determinadas épocas do ano, sendo mais comum em área rural (Almeida et al. 1985). Também, está associada à decomposição de animais (Moura et al. 1997, 1998). Os adulros podem ser coletados em sardinha, ou outros peixes e cebola em decomposição (Almeida et al. 1985).

Esta espécie apresenta importância médico-veterinária por ser vetora de ovos de Dermatobia hominis (Guimarães \& Papavero 1999).

Material-tipo examinado: Holótipo macho (MNRJ): "Camanducaial Minas 1800 MTS $\backslash$ H. S. Lopes VI-1938"; Parátipos: "Camanducaial Minas 1800 MTS $\backslash$ H. S. Lopes VI-1938" (1 fêmea, MNRJ); "Bocaina [São Paulo] 1777\ Fazenda Lageado\Albuquerque\ Machado IV-51" (1 fêmea, MNRJ);

Material adicional examinado: Brasil. Paraná: Curitiba, Santa Felicidade, 10.iv.1975, A. Imbiriba col. (1 fêmea, DZUP); Curitiba, 10.x.1980, C. B. Jesus col. (1 fêmea, DZUP); idem, 17.xi.1980, idem (1 fêmea, DZUP); idem, 6.xii.1980, idem (1 fêmea, DZUP); idem, 11.iv.1980, idem (1 fêmea, DZUP); idem, 19.x.1982, R. Misiuta col. (1 fêmea, DZUP), idem, 13.ii.1985, [sem coletor] (1 fêmea, DZUP); idem, xii.1985, S. Laroca col. (1 fêmea, DZUP); Santa Catarina: Rio das Antas, i.1953, (5 fêmeas, MZSP); Rio Grande do Sul: Arroio Grande, Mauá, 19.vii.2002, R. F. Krüger col. (3 fêmeas, DZUP); idem, idem, 23.viii.2002, idem (1 fêmea, DZUP); 30.vii.2002, idem (1 fêmea, DZUP); idem, 22.xi.2002, idem (2 fêmeas, DZUP); idem, 17.i.2002, idem (1 fêmea, DZUP); idem, 24.i.2003, idem (1 fêmea, DZUP); idem, 31.i.2003, idem (1 fêmea, DZUP); idem, 7.ii.2003, idem (1 fêmea, DZUP); mesmo col, 21.ii.2003, idem (1 fêmea, DZUP); Canela, 1216.i.1984, M. Hoffmann col. (2 fêmeas, DZUP); Capão do Leão, Eclusa, 11.iv.2002, R. F. Krüger col. (1 fêmea, DZUP); idem, 5.vii.2002, idem (1 fêmea, DZUP); idem, 12.vii.2002, idem (1 fêmea, DZUP); idem, 16.viii.2002, idem (2 fêmeas, DZUP); idem, 6.ix.2002, idem (2 fêmeas, DZUP); idem, 13.ix.2002, mesmo col (1 fêmea, DZUP); idem, 27.ix.2002, idem (1 fêmea, DZUP); idem, 6.xii.2002, mesmo col (1 fêmea, DZUP); Morro Redondo, Santo Amor, 6.ix.2002, idem (1 fêmea, DZUP); idem, 11.x.2002, idem (1 fêmea, DZUP); idem, 9.v.2002,

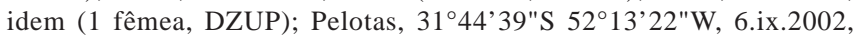
idem (1 fêmea, DZUP); idem, 27.ix.2002, idem (2 fêmeas, DZUP); idem, 18.x.2002, idem (1 fêmea, DZUP); idem, 15.xi.2002, idem (2 fêmeas, DZUP); idem, 22.xi.2002, idem (2 fêmeas, DZUP); idem, 17.i.2003, idem (5 fêmeas, DZUP); idem, 24.i.2003, idem (2 fêmeas, DZUP); idem, 31.i.2003, idem (3 fêmeas, DZUP); idem, 7.ii.2003, idem (5 fêmeas, DZUP); idem, 14.ii.2003, idem (1 fêmea, DZUP); Pelotas, 16.xii.2004, A. S. B. Souza col. (3 fêmeas, DZUP); idem, 3.vi.2005, idem (1 fêmea, DZUP).

Distribuição geográfica: Brasil: Minas Gerais, Rio de Janeiro, São Paulo, Paraná, Santa Catarina, Rio Grande do Sul.

\section{Fannia pusio (Wiedemann, 1830)}

(Figs. 30, 45, 81, 98, 116, 127, 144, 163, 182, 201, 220, 235, 250)

Diagnose: Macho apresenta na tíbia posterior na face ventral uma série de cerdas longas. Fêmea apresenta a placa fronto-orbital negra brilhante com a margem próxima aos olhos coberta com faixa de forte polinosidade prateada.

Redescrição: Macho: Comprimento total 3,0-3,5 mm (N=4); asa 2,5-3,0 $\mathrm{mm}(\mathrm{N}=3)$. Holóptico. Olhos nus. Cerdas frontais em número de dez a 13 pares (Fig. 30). Parafaciália com uma série de pequenos cílios. Placa fronto-orbital, vita frontal, parafaciália, gena e face com polinosidade prateada. Escapo e pedicelo negros. Flagelômero coberto com forte polinosidade cinza-escura. Arista castanho-escura com fraca pubescência. Palpo castanho-escuro e filiforme, o ápice com praticamente a mesma largura da base. Tórax negro. Caliptras esbranquiçadas. Halter e asa amarelados. Duas pré-alares. Pernas castanhoescuras. Tíbia média na face posterior com uma cerda submediana. Coxa posterior na face posterior com dois cílios. Fêmur posterior na face ventral com uma protuberância préapical onde se inserem na face anteroventral um conjunto de seis a sete cerdas longas e curvas (Fig. 81) e na face posteroventral três a quatro cerdas (Fig. 98). Tíbia posterior na face ventral com uma a duas séries de cerdas longas (Fig. 81); na face anterior com uma série de cerdas curtas (Fig. 81). Abdome trimaculado (Fig. 116). Estenito I nu. Esternito V (Fig. 144). Processo baciliforme ausente. Terminália (Figs. 163 e 182): padrão do subgrupo pusio (ver redescrição de $F$. femoralis), exceto, ausência da projeção posterior do surstilo. Hipândrio e estruturas associadas (Figs. 201, 220).

Fêmea semelhante ao macho, exceto: Comprimento total 3,0-3,5 mm (N=3); asa 2,5-3,0 $\mathrm{mm}(\mathrm{N}=3)$. Dicóptica. Cerdas frontais pequenas em número de dez pares (Fig. 45). Placa fronto-orbital negra brilhante com a margem próxima aos olhos coberta com faixa de forte polinosidade prateada (Fig. 45). Fêmur posterior na face posteroventral sem o conjunto de cerdas e na face anteroventral sem a série de cerdas. Tíbia posterior na face ventral com uma a duas cerdas medianas. Abdome inteiramente castanho-escuro (Fig. 127). Terminália: (Fig. 235): padrão do subgrupo pusio (ver redescrição de $F$. femoralis). Duas espermatecas (Fig. 250).

Comentários: F. pusio pertence ao subgrupo pusio (grupo canicularis) (Chillcott 1961; Albuquerque et al. 1981). Neste subgrupo as espécies podem ser muito similares entre si, principalmente as fêmeas. Al Gazi et al. (2004), baseados em 


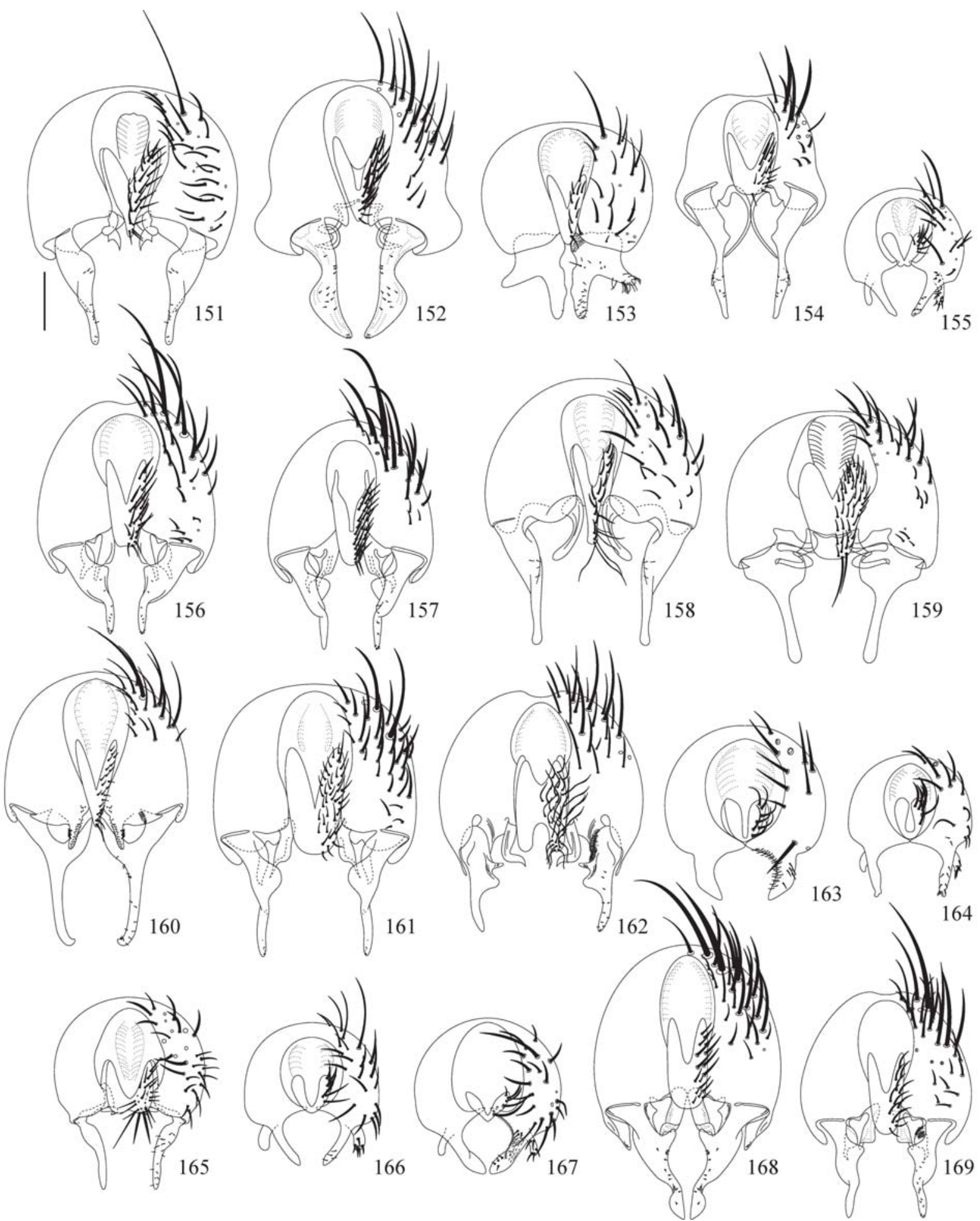

Figs. 151-169. Terminália, vista dorsal, macho: epândrio, placa cercal e sustilo: 151, F. admirabilis; 152, F. albitarsis; 153, F. canicularis; 154, F. carvalhoi; 155, F. femoralis; 156, F. flavicincta; 157, F. heydenii; 158, F. itatiaiensis; 159, F. obscurinervis; 160, F. opsia sp. nov.; 161, F. penicillaris; 162, F. pulvinilenis; 163, F. pusio; 164, F. sabroskyi; 165, F. scalaris; 166, F. snyderi; 167, F. trimaculata; 168, F. tumidifemur; 169, F. yenhedi. Escala: $0,2 \mathrm{~mm}$.

microscopia eletrônica, constataram que fêmeas de $F$. pusio diferem das fêmeas de F. trimaculata devido ao maior tamanho do triângulo ocelar entre as cerdas frontais, a vita frontal menor e menos polinosa e ao palpo ligeiramente menor. Entretanto, o caráter mais evidente na fêmea de $F$. pusio é a placa frontoorbital negra brilhante com a margem próxima aos olhos coberta com faixa de forte polinosidade prateada.

Foram utilizados espécimes de $F$. pusio oriundos de outros 
estados brasileiros, devido à falta de material nas coleções observadas para os estados da Região Sul. A espécie foi assumida para esta região, pois foi registrada por Pinto \& Brum (1998) e Carvalho et al. (2002), além de apresentar ampla distribuição geográfica.

Biologia: F. pusio apresenta hábito sinantrópico (Linhares 1981; Campos \& Barros 1995; Carvalho et al. 2002). Os adultos podem ser coletados em uma grande variedade de matéria orgânica em decomposição como peixe, moluscos e cobras mortos e fungos (Chillcott 1961), rato (Monteiro-Filho \& Penereiro 1987), fezes de aves poedeiras (Bruno et al. 1992), além disso, podem ser coletados em armadilhas com fezes humanas, vísceras de frango, frutas em decomposição e rim bovino (Marchiori et al. 2002) e vísceras de boi (dados de estiqueta).

Pela grande importância econômica desta espécie, os aspectos bionômicos e a biologia são uns dos mais estudados dentro do gênero, para a Região Neotropical (ver Carvalho et al. 2003), como a oogênese (Couri 1992a, b), o desenvolvimento dos imaturos (Marchiori \& Prado 1996a), o padrão e o horário de emergência dos adultos (Marchiori \& Prado 1996b), a dinâmica populacional (Lomônaco \& Prado 1994; Marchiori \& Prado 1999), a longevidade e a fecundidade (Marchiori \& Prado 1995) e os inimigos naturais, principalmente parasitóides (Bruno et al. 1992; Marchiori et al. 2005).

Material-tipo (não examinado). Lectótipo macho e paralectótipos depositados no Museum Zoological University of Copenhagen (Carvalho et al. 2003).

Material examinado: Brasil. Mato Grosso do Sul: Campo Grande, 13.ix.1999, W. W. Koller col. (1 macho, 2 fêmeas, DZUP); idem, 27.ix.1999, idem (1 fêmea, DZUP); idem, 30.ix.1999, idem (2 machos, DZUP); idem, 18.x.1999, idem (1 macho, 1 fêmea DZUP); idem, 12.i.2000, idem (1 fêmea, DZUP); idem, 2.iii.2000, idem (1 fêmea, DZUP); idem 28.vi.2002, idem (1 fêmea, DZUP); Rio de Janeiro, Rio de Janeiro, Restinga Jacareí, sem data, C. Lomônaco (5 machos, 4 fêmeas).

Distribuição geográfica: América do Norte, Guatemala, Panamá, El Salvador, Ilhas Guadalupe, Porto Rico, Cuba, Bahamas, Trinidade, Venezuela, Guiana, Chile, Ilhas Galápagos, Ilha de Páscoa, Pacífico, Leste da África, Mediterrâneo, Brasil (Carvalho et al. 2003) e Argentina (Dominguez 2007).

Brasil: Bahia, Goiás, Mato Grosso, Mato Grosso do Sul, Rio de Janeiro, São Paulo, Rio Grande do Sul.

\section{Fannia sabroskyi Seago, 1954}

(Figs. 31, 82, 99, 145, 164, 183, 202, 221)

Diagnose: Macho com o fêmur posterior na face ventral com uma leve protuberância pré-apical na qual na face posteroventral inserem-se um conjunto de cerdas longas, na face anteroventral há uma série de cerda a partir do terço basal, tornando-se mais longas para o ápice. Fêmea possui a parafrontália inteiramente negra.

Redescrição: Macho: Comprimento total 2,5-3,5 mm (Seago 1954). Holóptico. Olhos nus. Cerdas frontais em número de dez a 11 (Fig. 31). Parafaciália com uma série de pequenos cílios. Placa fronto-orbital, vita frontal, parafaciália, gena e face com polinosidade prateada. Escapo e pedicelo negros. Flagelômero coberto com forte polinosidade cinza-escura. Arista com fraca pubescência e castanho-escura. Palpo castanho-escuro e filiforme, o ápice com praticamente a mesma largura da base. Tórax negro. Caliptras esbranquiçadas com as bordas amareladas. Halter e asa amarelados. Duas cerdas pré-alares. Pernas castanho-escuras. Tíbia média na face posterior com uma cerda submediana. Coxa posterior na face posterior com um a três cílios. Fêmur posterior na face ventral com uma leve protuberância pré-apical, na qual na face posteroventral se inserem um conjunto de cerdas longas (Fig. 99); face anterior com uma série de cerda a partir do terço basal, tornando-se mais longas para o ápice. Tíbia posterior na face anterior com uma série de sete cerdas; face anteroventral com uma cerda submediana (Fig. 82). Abdome trimaculado (padrão para o subgrupo pusio (Chillcott 1961), ver redescrição de F. pusio e figura 116). Esternito I nu. Esternito V (Fig. 145). Processo baciliforme ausente. Terminállia (Figs. 164 e 183): padrão do subgrupo pusio (ver redescrição $F$. femoralis). Hipândrio e estruturas associadas (Figs. 202, 221).

Segundo Seago (1954), fêmea semelhante ao macho, exceto: Dicóptica. Parafácilia inteiramente negra. Fêmur posterior na face posteroventral sem conjunto de cerdas. Tíbia posterior na face anterodorsal sem a série de cerdas. Abdome inteiramente negro brilhante.

Comentários: F. sabroskyi pertence ao subgrupo pusio (grupo canicularis) (Albuquerque et al. 1981). Fêmea de $F$. sabroskyi é diferenciada das demais espécies do subgrupo por apresentar a parafaciália inteiramente negra, sem polinosidade.

Almeida et al. (1985) mencionaram o depósito de um exemplar de F. sabroskyi coletado em Curitiba (Paraná, Brasil) na coleção do DZUP, porém este material não foi encontrado. Por conseguinte, não foi encontrado material de F. sabroskyi oriundo do Sul do Brasil nas coleções investigadas, porém sua presença foi aqui assumida, baseada em Almeida et al. (1985) e Carvalho et al. (2002).

Biologia: espécie considerada sinantrópica (Almeida et al. 1985; Carvalho et al. 2002).

Material-tipo (não examinado). Holótipo macho depositado no American Museum of Natural History em Nova York, nos Estados Unidos (Carvalho et al. 2003).

Material examinado: Brasil. São Paulo: Serra do Japi, Jundiaí, 25.ii11.iii.1999, A.X. Linhares col. (1 macho, DZUP).

Distribuição geográfica: Guiana e Brasil (Carvalho et al. 2003). Brasil: Rio de Janeiro, São Paulo e Paraná.

Fannia scalaris (Fabricius, 1794)

(Figs. 32, 46, 66, 67, 82, 100, 117, 128, 146, 165, 184, 203, 222, 236, 251)

Diagnose: Macho apresenta a coxa média com três cerdas 


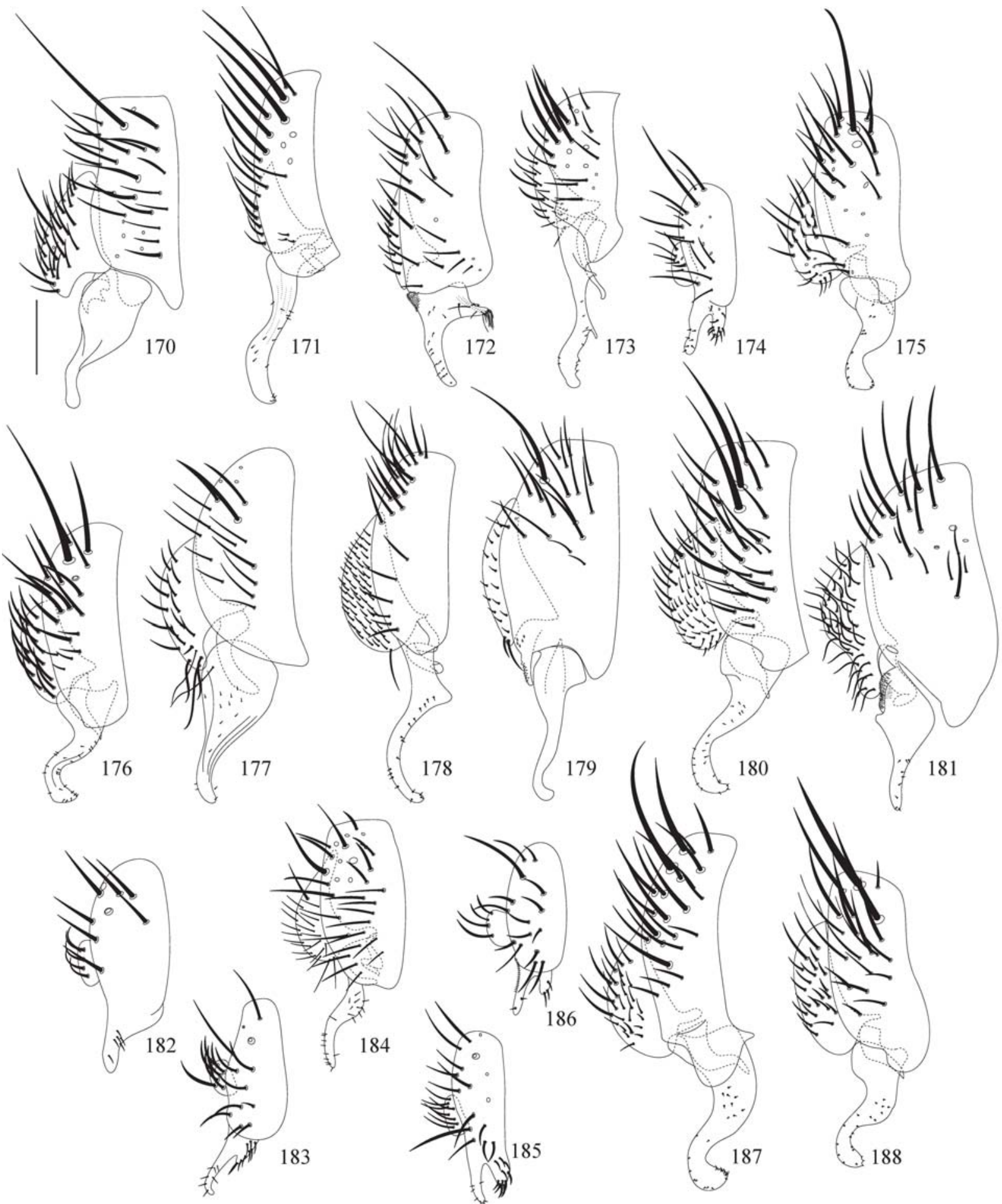

Figs. 170-188. Terminália, vista lateral, macho: epândrio, placa cercal e sustilo: 170, F. admirabilis; 171, F. albitarsis; 172, F. canicularis; 173, F. carvalhoi; 174, F. femoralis; 175, F. flavicincta; 176, F. heydenii; 177, F. itatiaiensis; 178, F. obscurinervis; 179, F. opsia sp. nov.; 180, F. penicillaris; 181, F. pulvinilenis; 182, F. pusio; 183 , F. sabroskyi; 184, F. scalaris; 185, F. snyderi; 186, F. trimaculata; 187, F. tumidifemur; 188, F. yenhedi. Escala: $0,2 \mathrm{~mm}$.

fortes em forma de aguilhão e a tíbia média na face ventral com um tubérculo. A fêmea apresenta abdome alongado, cinzaazulado e a tíbia posterior na face anterodorsal com uma série de cerdas, a partir do terço basal.
Redescrição: Macho: Comprimento total 5,5-6,5 mm (N=5); asa 5,0-6,0 $\mathrm{mm}(\mathrm{N}=5)$. Holóptico. Olhos nus. Cerdas frontais em número de nove a 11 pares (Fig. 32). Vita frontal negra. Placa fronto-orbital, parafaciália e gena com forte polinosidade prateada. Face cinza. Escapo, pedicelo e arista castanho- 
escuros. Flagelômero negro com forte polinosidade cinzaescura. Palpo castanho-escuro e clavado, com ápice medindo cerca de duas vezes a largura da base. Escuto cinza-azulado com duas estreitas listras castanhas. Caliptras brancoamareladas com as bordas amareladas. Halter amarelo. Asa amarelada. Uma cerda pré-alar. Pernas castanho-escuras. Tíbia anterior na face anterodorsal com uma cerda submediana. Coxa média com três cerdas fortes em forma de aguilhão (Fig. 66). Tíbia média na face ventral com um tubérculo submediano (Fig. 67); face posterior com uma cerda submediana. Coxa posterior na face posterior com um cílio. Fêmur posterior na face posterior sem cerdas diferenciadas (Fig. 100). Tíbia posterior na face anterodorsal com uma série de cerdas fortes, a partir do terço basal (Fig. 83); face anteroventral com três a cinco cerdas medianas (Fig. 83). Abdome alongado com uma listra mediana acastanhada e lateralmente com densa polinosidade cinzenta (Fig. 117). Esternito I ciliado. Esternito V (Fig. 146). Terminália (Figs. 165, 184): epândrio tão largo quanto longo, coberto uniformemente por cerdas curtas; placa cercal larga e bilobada na margem anterior, coberta por cerdas de diferentes tamanhos; surstilos afilados; processo baciliforme espiralado. Hipândrio e estruturas associadas (Figs. 203, 222).

Fêmea similar ao macho, exceto: comprimento total 4,7-6,0 $\mathrm{mm}(\mathrm{N}=5)$; asa 4,4-5,4 mm (N=4). Dicóptica. Cerdas frontais em número de três a quatro pares intercalados por cinco a sete pares de pequenos cílios (Fig. 46). Placa fronto-orbital com uma a duas séries de cílios fortes. Par de cerdas orbitais inferiores divergentes. Coxa média sem cerdas em forma de aguilhões. Tíbia média sem tubérculo ventral. Abdome alongado, cinza-azulado (Fig. 128). Terminália (Fig. 236): cercos longos, aproximadamente duas vezes o comprimento da placa anal, e coberto por cerdas de diferentes tamanhos; placa anal mais larga que longa e coberta por cerdas uniformes; esternito VIII reduzido a duas placas ciliadas; esternitos VII e VI mais largos que longos. Três espermatecas piriformes e não rugosas (Fig. 251).

Comentários: F. scalaris é a única espécie do grupo scalaris, o qual é caracterizado, principalmente, pela fêmea apresentar a placa cercal mais longa que larga, esternito VIII reduzido em dois pequenos escleritos e três espermatecas piriformes (Albuquerque et al. 1981).

Biologia: Conhecida como mosca da latrina, F. scalaris apresenta hábito sinantrópico (Almeida et al. 1985; Carvalho et al. 2002), pode estar associada a aterros sanitários, latrina e fossas sépticas (Chillcott 1961; Queiroz \& Carvalho 1987). As larvas se desenvolvem em praticamente todo tipo de matéria orgânica como, por exemplo: fungos, excrementos, lixo e matéria vegetal em decomposição e podem ainda estar associadas a ninhos de Vespidae e pássaros (Chillcott 1961).

Os adultos podem ser coletados em armadilhas com sardinha fresca, fígado cru de galinha e cebola em decomposição (Almeida et al. 1985), ou com camarão e frutas em decomposição (dados de etiqueta).
Esta espécie pode apresentar importância econômica, também, por ser vetora de ovos de D. hominis (Guimarães \& Papavero 1999).

Material-tipo (não examinado). Lectótipo macho e paralectótipos depositados no Zoological Museum University of Copenhagen (ZMUC) (Carvalho et al. 2003).

Material examinado: Brasil. Paraná: Curitiba, 19.x.1982, R. Misiuta col. (1 macho, DZUP); idem, 18.i.1984, A. C. Saad (3 fêmeas, DZUP); Curitiba, Uberaba, 15.x [sem ano], D. Takaki col. (1 fêmea, DZUP); idem, 29.x. [sem ano], idem (1 fêmea, DZUP); idem, 4.xii [sem ano], idem (1 fêmea, DZUP); idem, 23.ix.1975, A. Imbiriba col. (1 fêmea, DZUP), idem, 25.ix.1975, idem (2 fêmeas, DZUP); idem, 16.x.1975, idem (1 fêmea, DZUP); idem, 12.xi.1975, idem, (2 fêmeas, DZUP), idem, 19.xi.1975, idem (2 machos, DZUP); idem, 27.xi.1975, idem (1 macho, DZUP); idem, 3.xii.1975, idem (1 macho, DZUP); idem, 10.xii.1975, idem (6 fêmeas, DZUP); idem, 21.i.1976, idem (1 fêmea, DZUP); Estrada do Cerne, Km 11, 11.ii.1976, idem (2 fêmeas, DZUP).

Distribuição geográfica: Cosmopolita, não encontrada apenas em regiões fortemente tropicais e no ártico (Chillcott 1961), sendo mais comum em regiões temperadas (Carvalho et al. 2003).

\section{Fannia snyderi Seago, 1954}

(Figs. 33, 47, 84, 101, 147, 166, 185, 204, 223, 237, 252)

Diagnose: Macho apresenta uma forte protuberância na face ventral pré-apical com um forte conjunto de cerdas curtas e truncadas. A fêmea apresenta na placa fronto-orbital uma faixa acinzentada estreita e fraca, próxima ao olho.

Redescrição: Macho: comprimento total 3,0-3,5 mm (N=2); asa 2,5-3,0 $\mathrm{mm}(\mathrm{N}=2)$. Holóptico. Olhos nus. Cerdas frontais em número de dez a 11 pares (Fig. 33). Parafaciália com uma série de pequenos cílios. Placa fronto-orbital, vita frontal, parafaciália, gena e face com polinosidade prateada. Escapo e pedicelo negros. Flagelômero coberto com forte polinosidade cinza-escura. Arista com fraca pubescência e castanho-escura. Palpo castanho-escuro e filiforme, ápice com praticamente a mesma largura da base. Tórax negro. Caliptras esbranquiçadas. Halter e asa amarelados. Duas pré-alares. Pernas castanhoescuras e pulvilos amarelados. Fêmur anterior na face posteroventral com três a quatro cerdas a partir do terço apical. Tíbia média na face posterior com uma cerda mediana. Coxa posterior na face posterior com um a dois cílios. Fêmur posterior na face ventral com uma forte protuberância ao qual se inserem um forte conjunto de cerdas curtas e de ápice truncado (Fig. $84,101)$. Tíbia posterior na face anterior com uma série de seis a sete cerdas a partir do terço basal (Fig. 84); face antereventral com uma cerda submediana. Abdome trimaculado (padrão para o subgrupo pusio (Chillcott 1961), ver redescrição de F. pusio e figura 116). Esternito V (Fig. 147). Terminália (Figs. 166, 185): padrão do subgrupo pusio (ver redescrição de $F$. femoralis). Hipândrio e estruturas associadas (Figs. 204, 223).

Fêmea similar ao macho, exceto: comprimento total $3,0 \mathrm{~mm}$ $(\mathrm{N}=2)$; asa 2,6-2,8 $\mathrm{mm}(\mathrm{N}=2)$. Dicóptica. Cerdas frontais em número de dez cerdas curtas e de tamanhos diferentes. Placa fronto-orbital negra brilhante com uma estreita faixa com polinosidade prateada, próxima aos olhos. Abdome 

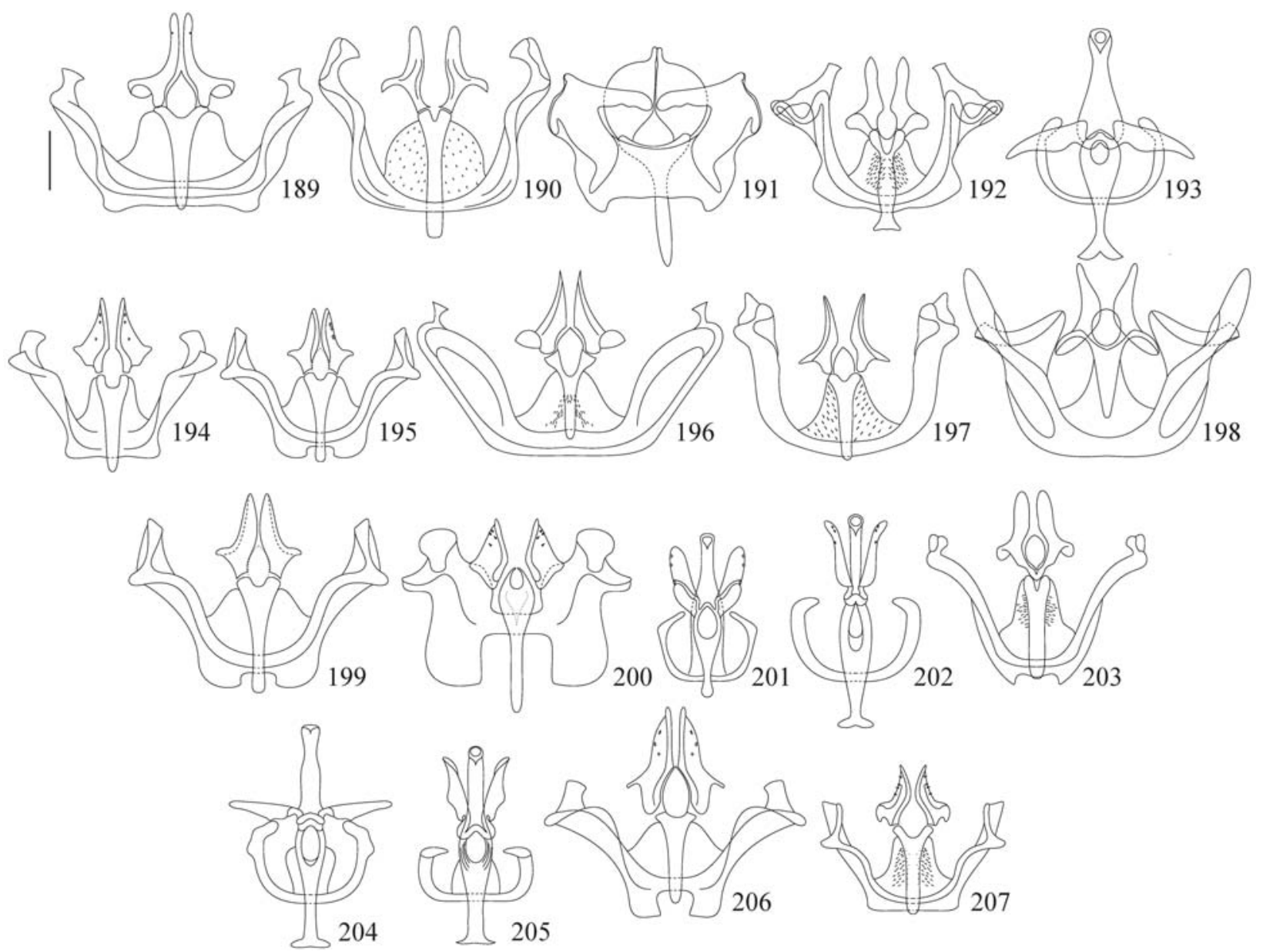

Figs. 189-207. Hipândrio e estruturas associadas, vista dorsal: 189, F. admirabilis; 190, F. albitarsis; 191, F. canicularis; 192, F. carvalhoi; 193, F. femoralis; 194, F. flavicincta; 195, F. heydenii; 196, F. itatiaiensis; 197, F. obscurinervis; 198, F. opsia sp. nov.; 199, F. penicillaris; 200, F. pulvinilenis; 201, F. pusio; 202, F. sabroskyi; 203, F. scalaris; 204, F. snyderi; 205, F. trimaculata; 206, F. tumidifemur; 207, F. yenhedi. Escala: $0,1 \mathrm{~mm}$.

inteiramente negro brilhante (padrão para o subgrupo pusio (Chillcott 1961), ver redescrição de F. pusio e figura 127). Terminália (Fig. 237): padrão do subgrupo pusio (ver redescrição de F.femoralis). Duas espermatecas (Fig. 252).

Comentários: F. snyderi pertence ao subgrupo pusio (grupo canicularis) (Chillcott 1961; Albuquerque et al. 1981).

Almeida et al. (1985) mencionaram o depósito de dez exemplares de F. snyderi coletados em Curitiba (Paraná, Brasil) na coleção do DZUP, porém este material não foi encontrado. Como não foi observado material da região Sul do Brasil nas coleções examinadas, foram utilizados espécimes de outras regiões brasileiras.

Biologia: espécie considerada sinantrópica (Almeida et al. 1985; Carvalho et al. 2002). Os adultos podem ser coletados em cebola em decomposição e fígado cru de galinha (Almeida et al. 1985).

Material-tipo (não examinado). Holótipo macho depositado no American Museum of Natural History em Nova York, nos Estados Unidos (Carvalho et al. 2003).
Material examinado: Brasil. Minas Gerais: Araxá, 22.ii.1965, C. T. \& C. Elias col. (1 macho, 2 fêmeas, DZUP); Viçosa, 29.iv.1987, M. F. Vieira (1 macho, DZUP).

Distribuição geográfica: Estados Unidos e Brasil (Carvalho et al. 2003).

Brasil: Minas Gerais e Paraná.

\section{Fannia trimaculata (Stein, 1898)}

(Figs. 34, 48, 85, 102, 148, 167, 186, 205, 224, 238, 253)

Diagnose: Macho apresenta o fêmur posterior na face anteroventral com uma série de cerdas curtas. Fêmea apresenta a placa fronto-orbital negra brilhante com a margem ao redor dos olhos coberta com fraca polinosidade prateada, e na tíbia posterior na face ventral apenas uma cerda mediana.

Redescrição: Macho: Comprimento total de 3,0-3,5 mm $(\mathrm{N}=4)$; asa 2,7-3,4 mm ( $\mathrm{N}=4)$. Holóptico. Olhos nus. Cerdas frontais em número de dez a 14 pares (Fig. 34). Parafaciália com uma série de pequenos cílios. Vita frontal negra. Placa frontoorbital, parafaciália, gena e face com polinosidade prateada. 

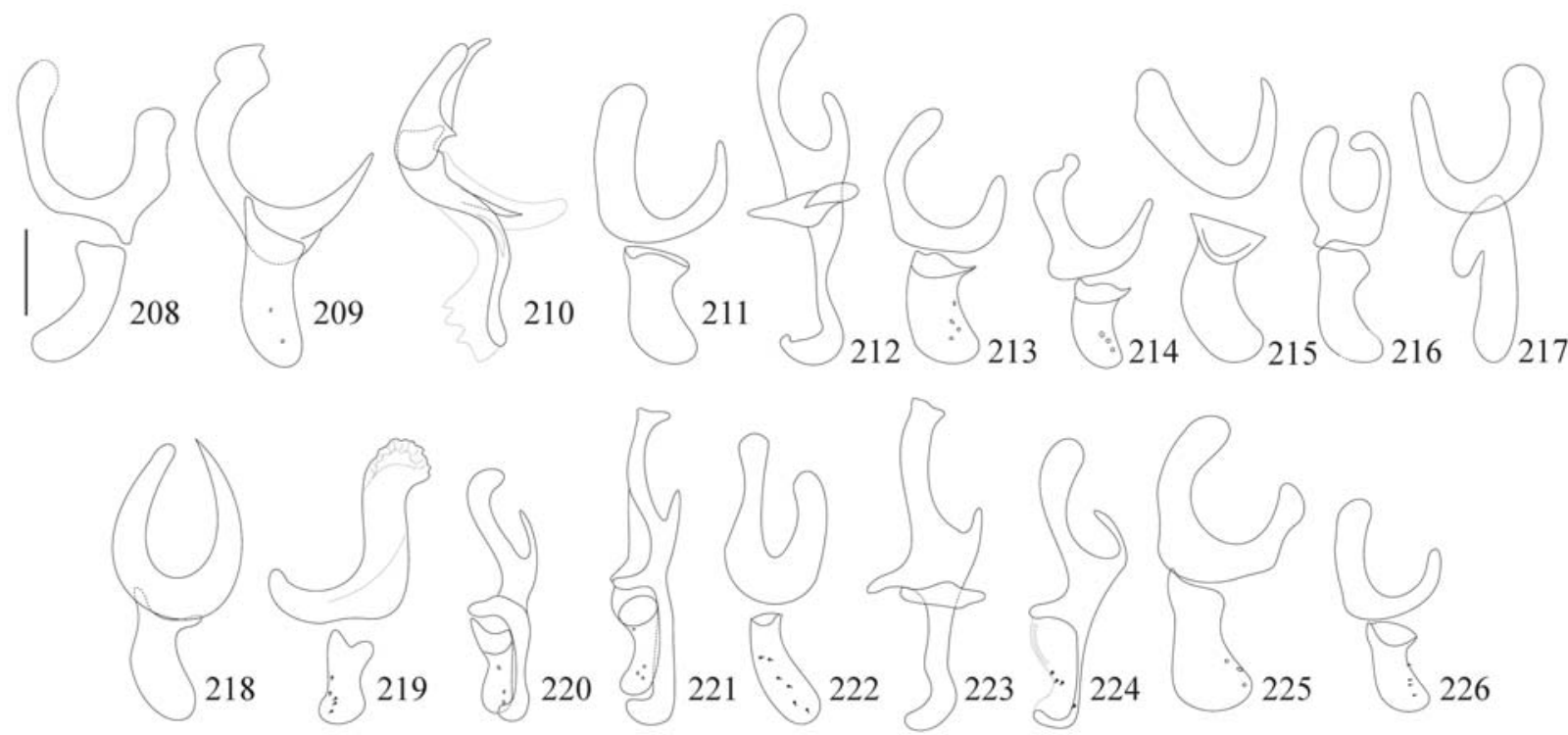

Figs. 208-226. Hipândrio e estruturas associadas, vista lateral: 208, F. admirabilis; 209, F. albitarsis; 210, F. canicularis; 211, F. carvalhoi; 212, F. femoralis; 213, F. flavicincta; 214, F. heydenii; 215, F. itatiaiensis; 216, F. obscurinervis; 217, F. opsia sp. nov.; 218, F. penicillaris; 219, F. pulvinilenis; 220, F. pusio; 221, F. sabroskyi; 222, F. scalaris; 223, F. snyderi; 224, F. trimaculata; 225, F. tumidifemur; 226, F. yenhedi. Escala: $0,1 \mathrm{~mm}$.

Escapo e pedicelo negros. Flagelômero coberto com forte polinosidade cinza-escura. Arista com fraca pubescência e castanho-escura. Palpo castanho-escuro e filiforme, ápice com a mesma largura da base. Tórax negro. Caliptras, halter e asa amarelados. Duas cerdas pré-alares. Pernas castanho-escuras e pulvilos amarelados. Fêmur anterior na face posteroventral com três a quatro cerdas pré-apicais. Tíbia média na face posterior com uma cerda. Coxa posterior na face posterior com dois cílios. Fêmur posterior na face anteroventral com uma série de cerdas curtas do terço basal ao terço apical (Fig. 85); face posteroventral com um conjunto de cinco a seis cerdas longas e curvas pré-apicais (Fig. 102). Tíbia posterior na face ventral com uma cerda mediana; face anterodorsal com uma série de cerdas curtas do terço basal à porção pré-apical (Fig. 85). Abdome trimaculado (padrão para o subgrupo pusio (Chillcott 1961), ver redescrição de $F$. pusio e figura 116). Estenito I nu. Esternito V (Fig. 148). Terminália (Figs. 167 e 186): padrão do subgrupo pusio (ver redescrição de $F$. femoralis). Hipândrio e estruturas associadas (Figs. 205, 224).

Fêmea: semelhante ao macho, exceto: comprimento total 3,0-3,5 mm ( $=4)$; asa 2,5-3,2 mm ( $\mathrm{N}=2)$. Dicóptica. Triângulo ocelar alongado até o nível do sexto par de cerdas frontais. Cerdas frontais pequenas em número de dez pares (Fig. 48). Placa fronto-orbital negra brilhante com a margem próxima aos olhos coberta com fraca polinosidade prateada (Fig. 48). Fêmur posterior na face posteroventral sem o conjunto de cerdas; face anteroventral sem a série de cerdas. Tíbia posterior na face anterodorsal sem série de cerdas. Abdome inteiramente castanho-escuro (padrão para o subgrupo pusio (Chillcott 1961), ver redescrição de $F$. pusio e figura 127). Terminália (Fig. 238): padrãpo do subgrupo pusio (ver redescrição de $F$. femoralis). Duas espermatecas (Fig. 253).
Comentários: F. trimaculata pertence ao subgrupo pusio (grupo canicularis) (Albuquerque et al. 1981).

Primeiro registro para Santa Catarina.

Biologia: F. trimaculata possui hábito sinantrópico (Carvalho et al. 2002), podendo ser encontrada em altas densidades em granja avícolas (Bruno et al. 1992, 1993).

Material-tipo (não examinado). Síntipos depositados no Museum of Comparative Zoology (MCZ) em Cambridge nos Estados Unidos; Field Museum of Natural History (FMNH) em Chicago nos Estados Unidos; National Museum of Natural History (USNM) em Washington nos Estados Unidos e no Zoological Museum University of Copenhagen (ZMUC) em Copenhagen (Carvalho et al. 2003).

Material examinado: Brasil. São Paulo: Bauru, 25.vii.1988, T. V. Bruno col. (3 machos, 3 fêmeas, DZUP); Bady Bassitt, 12.ix.1988, idem (2 machos, 2 fêmeas, DZUP); Ibiúna, i.1986, idem (2 machos, 1 fêmea, DZUP); Itapetininga, 2.v.1988, idem (4 machos, 2 fêmeas, DZUP); Pindamonhangaba, 1.iii.1988, idem (2 machos, 2 fêmeas, DZUP); Sorocaba, 25.ix.1988, idem (2 fêmea, DZUP); Jundiaí, Serra do Japi, 22.ii-22-iii.1999, A. X. Linhares col.(1 fêmea, DUZUP); idem, 25.ii-10.iii.1999, idem (1 fêmea, DZUP); idem, 4-30.iii.1999. idem (1 fêmea, DZUP); Paraná: Curitiba, 16.ii.1966, C. Ext. (1 fêmea, DZUP); idem, 18.i.1982, L. Dudas col. (1 fêmea, DZUP); Curitiba, Capão da Imbuia, 13.ii.1985, S. R. Malkoaski col. (2 fêmeas, DZUP); idem, 14.ii.1985, idem (1 fêmea, DZUP); idem, 15.ii.1985, idem, (1 fêmea, DZUP); idem, 8.iii.1985, idem (1 fêmea, DZUP); idem, 13.iii,1988, idem (1 fêmea, DZUP); Curitiba, Represa de Piraquara II, 19.i.2000, C. J. B. de Carvalho col. (1 fêmea, DZUP); Guaratuba, 7.ii.1966, C. Dipterologia (1 macho, 1 fêmea, DZUP); Palmas, Rio Iratim, 16.i.1992, R. Misiuta (1 fêmea, DZUP); Santa Catarina: Itajaí, EMPASC, x.1988, C. G. Paloschi (2 fêmeas, DZUP); idem, xi.1988, idem (1 fêmea, DZUP); Nova Teotônia, viii.1967, F. Plaumann (1 fêmea, MZSP); idem, iv.1971, idem (2 fêmeas, MZSP); idem, v.1971, idem, (1 macho, MZSP); idem, vi.1971, idem (2 machos, 1 fêmea, MZSP); idem, vii.1971, idem (2 machos, MZSP); idem, x.1971, idem (1 fêmea, MZSP), idem, xi.1971, idem, (2 machos e 3 fêmeas, MZSP); idem, vii.1972, idem, (1 fêmea, MZSP); Rio das Antas, i.1953, Camargo col. (1 fêmea, MZSP). Rio 
Grande do Sul: Barão de Cotegipe, 15.i.1967, F. Giacomel col. (2 machos, 1 fêmea, MZSP); idem, 25.i.1967, idem (1 fêmea, MZSP).

Distribuição geográfica: América do Norte, Jamaica, Belize, Panamá, Porto Rico, República Dominicana, Haiti, Santo Domingo, Equador, Peru, Venezuela, Uruguai e Argentina (Carvalho et al. 2003).

Brasil: Bahia, Minas Gerais, Roraima, Rio de Janeiro, São Paulo, Paraná, Santa Catarina, Rio Grande do Sul.

\section{Fannia tumidifemur Stein, 1911}

(Figs. 35, 68, 86, 103, 118, 149, 168, 187, 206, 225)

Diagnose: Macho com número de cerdas frontais de dez a 12 pares, escuto e escutelo inteiramente castanho, asa acastanhada, fêmur posterior nas faces ventral e posteroventral com uma forte protuberância pré-apical, onde se inserem um conjunto de cerdas longas e de ápice curvo, formando um forte tufo.

Redescrição: Macho: Comprimento total 4,8-6,0 mm (N=6); asa 4,0-5,5 mm (N=6). Holóptico. Olhos nus. Cerdas frontais em número de dez a 12 pares (Fig. 35). Vita frontal negra. Placa fronto-orbital, parafaciália, gena e face cobertos com forte polinosidade prateada. Escapo, base do pedicelo e ápice da arista castanho-escuros. Ápice do pedicelo e base da arista castanho-claros. Flagelômero coberto com densa polinosidade cinzenta. Arista com fraca pubescência. Palpo castanho-escuro e fortemente clavado, com o ápice medindo cerca de três vezes a largura da base. Escuto e escutelo homogeneamente castanho. Pleuras acinzentadas. Uma cerda pré-alar. Caliptras esbranquiçadas, podendo apresentar a borda amarelada ou acastanhada. Halter amarelo. Asa acastanhada. Pernas castanho-escuras e pulvilos branco-amarelados. Fêmur anterior na face posteroventral com uma série de cerdas a partir do terço apical. Tíbia média na face posterior com uma cerda mediana; faces ventral e anteroventral com uma cerda apical forte (Fig. 68). Tarso basal médio na face ventral sem cerdas de revestimento na porção basal. Coxa posterior na face posterior com duas a três cerdas. Fêmur posterior nas faces ventral e posteroventral com uma forte protuberância pré-apical, onde se inserem um conjunto de cerdas longas e de ápice curvo, formando um forte tufo (Fig. 103). Tíbia posterior na face anteroventral com quatro a seis cerdas (Fig. 86). Abdome alongado com tergitos I-IV lateralmente amarelotranslúcidos e com uma listra mediana castanho-escura, tergito V castanho acinzentado (Fig. 118). Esternito I ciliado. Esternito V (Fig. 149). Terminália (Fig. 168, 187): padrão do grupo heydenii (ver redescrição de $F$. flavicincta). Hipândrio e estruturas associadas (Figs. 206, 225).

Comentários: $F$. tumidifemur pertence ao grupo heydenii (Albuquerque et al. 1981).

Primeiro registro para o estado de Santa Catarina.

Biologia: F. tumidifemur possui hábito sinantrópico (Almeida et al. 1985; Carvalho et al. 2002). Pode ser coletada em sardinha, cebola em decomposição, fígado cru de galinha (Almeida et al. 1985).

Material-tipo (não examinado). Lectótipo macho e paralectótipos fêmeas, depositados no Staatliches Museum für Tierkunde, na Alemanha (Carvalho et al. 2003).

Material examinado: Brasil. Paraná: Curitiba, 14.iii.1981, C. B. Jesus col. (1 macho, DZUP); Fênix, 30.ix.1985, Esc. Departamento de Zoologia col. (1 macho, DZUP); idem, 1.x.1985, idem (3 machos, DZUP); Fênix, Reserva Estadual, ITCF, 4.viii.1986, Levantamento Entomológico PROFAUPAR col.(4 machos, DZUP); idem, 11.viii.1986, idem (1 macho, DZUP); idem, 24.xi.1986, idem (1 macho, DZUP); Fênix, Reserva Estadual, Vila Rica, 3.viii.1987, idem (1 macho, DZUP); idem, 9.xi.1987, idem (1 macho, DZUP); idem, 4.iv.1988, idem (1 macho, DZUP); idem, 18.iv.1988 (1 macho, DZUP); Iguaçú, xii.1941, Com. E. N. V. col. (6 machos, MNRJ); Guairá, xi.1941, Com. E. N. V. col. (1 macho, MNRJ); Pinhão, Salto Segredo, 15.i.1992, R. Misiuta col. (8 machos, DZUP); idem, 19.i.1992, mesmo col (8 machos, DZUP); Telêmaco Borba, Reserva Biológica Samuel Klabin 4.viii.1986, Levantamento Entomológico PROFAUPAR col. (1 macho, DZUP); idem, 12.x.1987, idem (2 machos, DZUP); Terra Boa, 1-3.i.1985, J. A. Rafael (1 macho, DZUP); Piraquara, 9.v.1974, J. Ferreira col. (1 fêmea, DZUP); Tijucas do Sul, Vossoroca, Br 468, Km 54, iii.1981, C. J. B de Carvalho col. (5 fêmeas, DZUP); Santa Catarina: Florianópolis, vii.1960, Casemiro col. (1 macho, MZSP); Nova Teotônia, vii.1967, F. Plaumann col. (2 machos, MZSP); idem, iv.1970, idem (1 macho, MZSP) idem, v.1970, idem (7 machos, MZSP); idem, vi.1970, idem (4 machos, MZSP); idem, x.1970, idem (2 machos, MZSP); idem, xi.1970, idem (4 machos, MZSP); Paraguai. Jejui-mi, Departamento Canindeyú, Reserva Natural do Bosque Mbaracayú, Bosque Baixo, 10-16.iv.1996, A. C. F. Costa (1 macho, DZUP); idem, 18-28.vii.1996.

Distribuição geográfica: México, Bolívia, Brasil (Carvalho et al. 2003), Paraguai. Argentina (Dominguez 2007).

Brasil: Mato Grosso, Goiás, Minas Gerais, Mato Grosso do Sul, Rio de Janeiro, São Paulo, Paraná, Santa Catarina, Rio Grande do Sul.

\section{Fannia xanthocera Albuquerque, 1954} (Figs. 49, 61, 129, 239, 254)

Diagnose: Antena e palpo inteiramente amarelos, escuto acinzentado com cinco listras castanho-claras, asa acastanhada e coxa posterior na face posterior nua.

Redescrição: Fêmea: comprimento total 4,5-5 mm (N=3); asa 4,3-4,7 $\mathrm{mm}(\mathrm{N}=3)$. Dicóptica. Olhos nus. Cerdas frontais em número de oito a dez pares de tamanhos diferentes (Fig. 49). Placa fronto-orbital com uma série de cílios. Cerda orbital inferior divergente e cerda orbital superior voltada para a porção posterior. Vita frontal negra ou ferrugínea aveludada. Placa fronto-orbital, parafaciália, gena e face acinzentada. Escapo, pedicelo e flagelômero amarelos. Flagelômero longo, medindo cerca de 2,5 o comprimento do pedicelo. Base da arista amarelada e ápice castanho, e com fraca pubescência. Palpo amarelo e clavado, ápice cerca de 1,5 vezes a base. Escuto acinzentado com cinco listras castanho-claras (Fig. 61). Base do escutelo castanho-clara e ápice acinzentado (Fig. 61). Caliptras e halter esbranquiçados. Asa acastanhada. Uma préalar. Pernas castanhas e pulvilos esbranquiçados. Tíbia média na face ventral com uma cerda no terço apical, face posterior com uma cerda mediana. Coxa posterior na face posterior nua. 

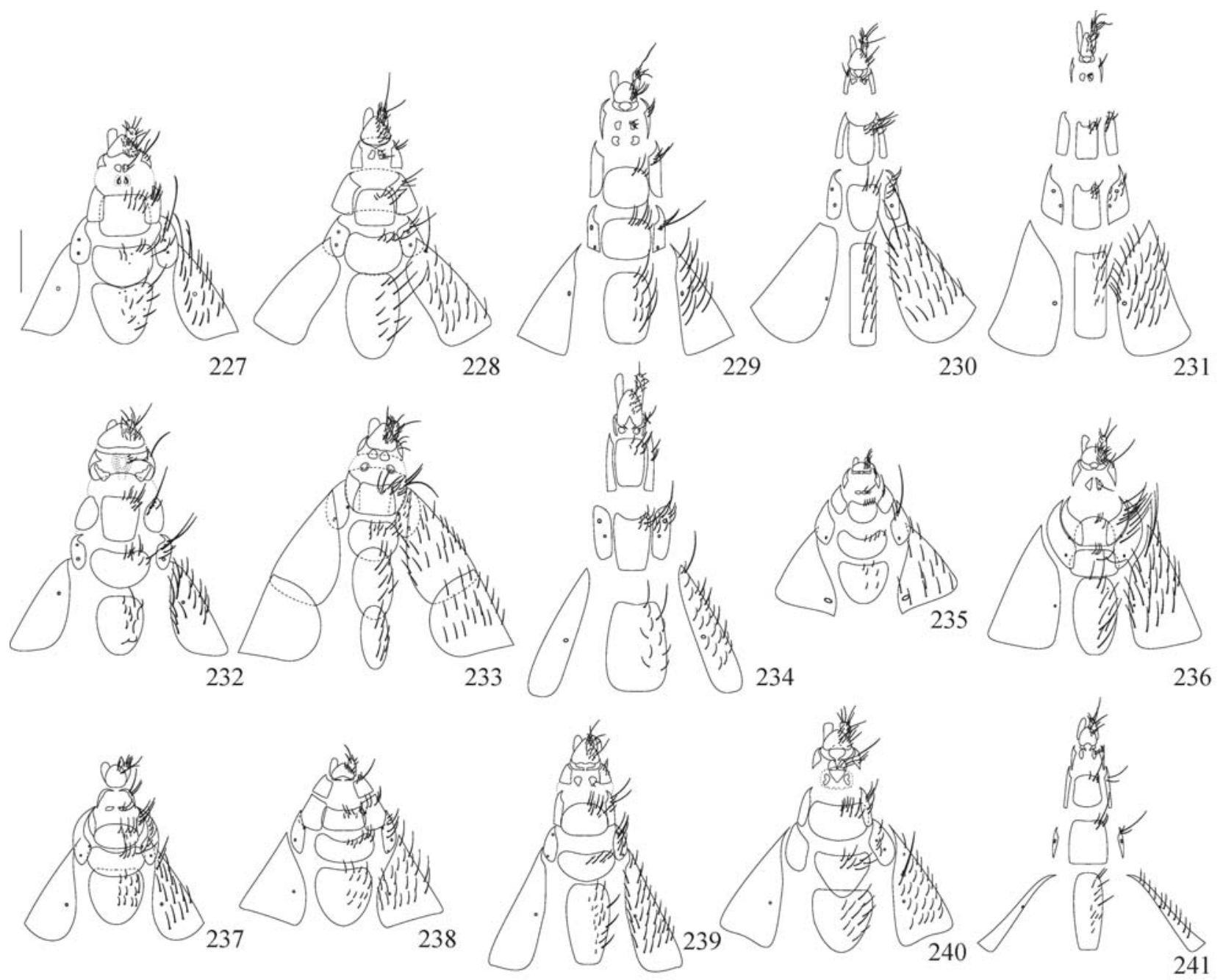

Figs. 227-241. Terminália, vista ventral, fêmea: 227, F. admirabilis; 228, F. albitarsis; 229, F. canicularis; 230, F. flavicincta; 231, F. heydenii; 232, F. itatiaiensis; 233, F. obscurinervis; 234, F. punctipennis; 235, F. pusio; 236, F. scalaris; 237, F. snyderi; 238, F. trimaculata; 239, F. xanthocera; 240, F. xanthothrichia; 241, F. yenhedi. Escala: $0,2 \mathrm{~mm}$.

Tíbia posterior na face anteroventral com duas cerdas medianas. Abdome com a base dos tergitos I-III amarelados e ápice dos tergitos I-III e demais tergitos castanhos com manchas acizentadas esparsas (Fig. 129). Esternito I nu. Terminália (Fig. 239): cercos curtos, pouco maiores que a placa anal; placa anal mais longa que larga coberta por cílios de diferentes tamanhos; esternito VIII reduzidos a duas placas com duas a três cerdas de mesmo tamanho; esternitos VII e VI mais largos que longos com duas séries horizontais de cerdas de diferentes tamanhos. Duas espermatecas esféricas e fracamente rugosas (Fig. 254).

Comentários: Os espécimes observados apresentaram variação, em relação ao material-tipo, quanto à coloração do halter. No material-tipo o halter possui a base castanha e o ápice amarelado, e nos demais espécimes o halter é interamente esbranquiçado.

F. xanthocera não consta no trabalho das espécies neotropicais de Albuquerque et al. (1981), consequentemente não foi proposto o seu posicionamento nos grupos de espécies conhecidos.

Macho desconhecido.

Primeiro registro para o Paraná.

Material-tipo examinado: Holótipo fêmea (MNRJ): 'Nova FriburgolEstado do Riol 900m 1-1946\ WYGOD. COL.' Parátipo fêmea (MNRJ): 'Goiânia\ Estado Goiaz\VII.1943\ Freitas \& Nobre.

Material adicional examinado: Brasil. Paraná, Fênix, Reserva Estância Vila Velha, 1.ii.1988, Levantamento Entomológico PROFAUPAR col. (1 fêmea, DZUP); idem, 27.vi.1988, idem (1 fêmea, DZUP); Jundiaí do Sul, Fazenda Monte Verde, 21.i.1988, idem (1 fêmea, DZUP); Telêmaco Borba, Reserva Biológica Samuel Klabin, 7.ix.1988, idem (1 fêmea, DZUP).

Distribuição geográfica: Brasil: Goiás, Rio de Janeiro, Paraná.

\section{Fannia xanthothrichia sp. nov.}

(Figs. 10, 14, 130, 240, 255)

Diagnose: Coloração geral amarelada, antena e palpos 
castanhos, arista pubescente, caliptras amarelas, halter com a base esbranquiçada e ápice castanho, asa leventente acastanhada e coxa posterior na face posterior ciliada.

Descrição: Holótipo fêmea: comprimento total de 5,0 mm; comprimento da asa: 4,8 mm. Dicóptica.

Cabeça (Figs. 10, 14): Olhos com cílios fracos, curtos e esparsos. Espaço interocular 0,4 vezes a largura da cabeça ao nível do ocelo anterior. Cerdas frontais em número de dois pares fortes e cinco pares de cerdas fracas. Triângulo ocelar negro com um par de cerdas anterovertidas e dois pares de cílios. Ocelos amarelos. Placa fronto-orbital, vita frontal, parafaciália, gena e face castanho-escuras. Placa fronto-orbital com duas séries desordenadas de cílios. Cerda orbital inferior divergente, cerda orbital superior voltada para a porção posterior da cabeça. Escapo e pedicelo castanho-claros. Flagelômero castanho-escuro coberto com forte polinosidae cinzenta. Flagelômero mede 2,8 vezes o tamanho do pedicelo. Arista pubescente, castanha com a base castanho-clara. Palpo castanho-escuro e clavado, com o ápice medindo cerca de 1,5 vezes a largura da base.

Tórax: Coloração geral amarela (Fig. 14); pleuras amarelas (Fig. 14); anepímero com mancha castanho-escura. Cerdas acrosticais pré-suturais em duas e três séries desordenadas e pós-suturais em três, quatro e cinco séries, terminadas em um par de cerdas pré-escutelares desenvolvidas. Cerdas dorsocentrais 2:3. Duas cerdas umerais, a interna menor. Uma cerda pós-umeral e uma pré-sutural maior. Duas cerdas notopleurais. Duas cerdas pré-alares pequenas. Uma cerda supra-alar. Duas cerdas intra-alares e duas pós-supra-alares. Escutelo amarelado. Um par de cerdas escutelares basais e um par de apicais desenvolvidas. Um par de cerdas laterais e um par de pré-apicais menores. Caliptras amareladas (Fig. 14). Caliptra inferior cerca de 0,5 vezes o tamanho da superior. Halter com a base esbranquiçada e ápice castanho (Fig. 14). Asa levemente acastanhada (Fig. 14).

Pernas: coxas, trocânteres e fêmures castanho-claros (Fig. 14). Tíbias castanho-escuras (Fig. 14). Tarsômeros enegrecidos (Fig. 14). Pulvilos pequenos e esbranquiçados (Fig. 14). Fêmur anterior nas faces posterodorsal e posteroventral com uma série completa de cerdas; face posterior com duas séries de cerdas menores. Tíbia anterior na face dorsal com uma cerda pré-apical forte; faces ventral e posterior com uma cerda apical forte; face anterodorsal com uma cerda no terço apical. Fêmur médio na face anterior com uma série completa de cerdas; face posterior com quatro cerdas fortes e curvas a partir do terço apical. Tíbia média na face ventral nua; face anterodorsal com uma cerda apical e uma cerda no terço apical; faces ventral e posteroventral com uma cerda apical, sendo a primeira mais forte; face posterior com três cerdas, uma apical, uma no terço apical e uma mediana. Coxa posterior na face posterior na perna esquerda com dois cílios e perna direita com um cílio. Fêmur posterior na face anteroventral no terço apical e pré-apical com uma cerda longa; face anterodorsal com uma série de cerdas as quais a partir do terço apical dirigem-se para a face dorsal. Tíbia posterior na face dorsal na porção média e pré- apical com uma cerda; face anterodorsal no terço apical com uma cerda; face anteroventral com três cerdas medianas e uma cerda apical forte.

Abdome: Base dos tergitos I-II amarelos, ápice dos tergitos I-II e tergitos III-V castanhos (Figs. 14, 130). Terminália (Fig. $240)$ : cercos 1,5 vezes maior que o comprimento da placa anal, coberto por cerdas de diferentes tamanhos, sendo as apicais mais longas; placa anal mais larga que longa coberta uniformemente por cerdas longas; esternito VIII reduzido em um par de placas posteriores esclerotinizadas e ciliadas, e em um par de placas anteriores pouco esclerotinizadas e não ciliadas; esternitos VII e VI mais largos que longos com duas séries de cerdas de tamanhos similares. Três espermatecas de formas diferente, uma hemiesférica e duas alongadas ambas levemente rugosas (Fig. 255).

Variação: Coloração do tórax variando de amarelada a castanho-clara, tíbia média na face posterior com duas a três cerdas e coxa posterior na face posterior com um ou dois cílios.

Comentários: Fannia xanthothrichia sp. nov. é similar a $F$. admirabilis devido à coloração geral do corpo, entretanto, pode ser facilmente separada pela coloração castanha da antena e dos palpos e pela ciliação da coxa posterior na face posterior.

Macho desconhecido.

Esta espécie por ser muito semelhante à $F$. admirabilis, tanto na morfologia externa quanto na terminália feminina, pode ser considerada pertencente ao grupo admirabilis, proposto por Albuquerque et al. (1981).

Segundo os dados de etiqueta, os exemplares observados foram coletados em armadilha luminosa.

O holótipo encontra-se em ótimo estado, colado em alfinete entomológico, apresentando todas as estruturas.

Material-tipo: Holótipo fêmea: 'S. JOSÉ DOS PINHAIS-PR\ Ser. Mar [Serra do Mar] Br $277 \mathrm{Km}$ 54\ BRASIL 02.XII.1986\ Lev. Ent. PROFAUPAR\LÂMPADA'; Paratipos: 'idem, 29.XI.1986, idem' (2 fêmeas, DZUP); 'S. JOSÉ PINHAIS- PR\ BRASIL (BR 277- KM 24)। 12-16-XI-1984 [escrito à mão] C.I.I.F. (LUMINOSA)' (2 fêmeas, DZUP).

Distribuição geográfica: Brasil: Paraná.

Etimologia: O epíteto específico refere-se à coloração geral do corpo amarela e a presença de cílios na coxa posterior (grego - xantho $=$ amarelo; thrichos $=$ cerda).

Fannia yenhedi Albuquerque, 1957

(Figs. 36, 50, 56, 62, 87, 107, 119, 131, 150, 169, 188, 207, 226, 241, 256)

Diagnose: Escuto cinza com três listras dorsais castanhas e escutelo com três manchas castanhas na base. Asa inteiramente amarelada. Macho apresenta de nove a dez pares de cerdas frontais. 


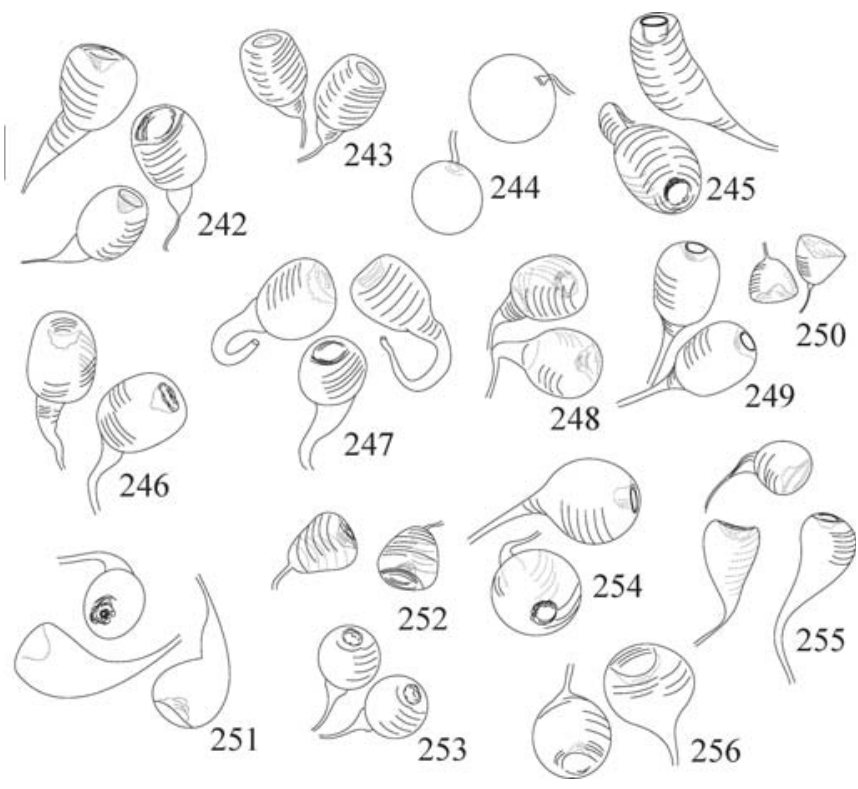

Figs. 242-256. Espermateca: 242, F. admirabilis; 243, F. albitarsis; $244, F$. canicularis; $245, F$. flavicincta; 246, F. heydenii; 247, F. itatiaiensis; 248, F. obscurinervis; 249, F. punctipennis; 250, F. pusio; $251, F$. scalaris; 252, F. snyderi; 253, F. trimaculata; 254, F. xanthocera; $255, F$. xanthothrichia; 256, F. yenhedi. Escala: $0,1 \mathrm{~mm}$.

Redescrição: Macho: Comprimento total 5,0-6,0 mm (N=5); asa 4,3-5,2 $\mathrm{mm}(\mathrm{N}=5)$. Holóptico. Olhos nus. Cerdas frontais de nove a dez pares (Fig. 36). Vita frontal castanho-escura a negra. Placa fronto-orbital, parafaciália, gena e face cobertas com densa polinosidade prateada. Escapo e pedicelo castanhos. Flagelômero negro coberto com forte polinosidade cinza. Base da arista castanho-clara e ápice castanho-escuro. Arista com fraca pubescência. Palpo castanho-escuro e clavado, com o ápice medindo cerca de 1,5 vezes a largura da base. Escuto cinza com três listras castanhas, as quais se estendem até o escutelo (Fig. 56). Escutelo cinza com três manchas castanhas na base (Fig. 56). Uma pré-alar. Caliptras brancas. Halter e asa amarelados. Tíbia média na face posterior com uma cerda submediana. Coxa posterior na face posterior ciliada. Fêmur posterior nas faces ventral e posteroventral com uma protuberância pré-apical onde se insere um forte tufo de cerdas de ápice curvo (Fig. 104). Tíbia posterior na face anteroventral com três a quatro cerdas medianas (Fig. 87). Abdome com tergitos I-IV lateralmente amarelo-translúcidos e com uma listra mediana castanho-escura, tergito $\mathrm{V}$ castanho acinzentado (Fig. 119). Esternito I ciliado. Esternito V (Fig. 150). Terminália (Figs. 169, 188): padrão do grupo heydenii (ver redescrição de F. flavicincta). Hipândrio e estruturas associadas (Figs. 207, 226).

Fêmea semelhante ao macho, exceto: comprimento total $4,5-5,5 \mathrm{~mm}(\mathrm{~N}=4)$; asa 3,8-4,5 $\mathrm{mm}(\mathrm{N}=4)$. Dicóptica. Cerdas frontais em número de seis a sete pares de diferentes tamanhos (Fig. 50). Cerda orbital inferior e superior voltadas para a porção posterior da cabeça (Fig. 50). Escuto acinzentado com três listras estreitas castanhas, as quais se estendem até a base do escutelo (Fig. 62). Tíbia média na face ventral com uma cerda no terço apical. Fêmur posterior nas faces ventral e posteroventral nuas. Abdome acinzentado com manchas castanhas (Fig. 131). Terminália (Fig. 241): padrão do grupo heydenii (ver redescrição de $F$. flavicincta). Duas espermatecas esféricas e levemente rugosas (Fig. 256).

Comentários: F. yenhedi, segundo Albuquerque et al. (1981), pertence ao grupo heydenii.

Primeiro registro para a região Sul do Brasil.

Biologia: F. yenhedi é comumente encontrada em ambientes antrópicos, apresentando maior densidade em áreas rurais (Linhares 1981).

Material-tipo examinado: Holótipo macho (MNRJ): 'GOM. INST. O. CRUZ\ ILHA SECA S. PAULO\ BRASIL 19-26.2.40'; Parátipos: 'Bodoquena\ Mato Grosso\XI-1941\ com. I. O. C.' (1 macho, DZUP); 'Campinas-Goyaz\ Borgmeier et\S. Lopes XII.1935' (1 fêmea, MNRJ); 'Calado-Rio Doce $\backslash$ Minas 12-15.11.39\ Martins \& Lopes' (1 fêmea, MNRJ); 'Rezende E. Riol 6-46. S. Oliveira' (1 macho, MNRJ); 'Rio de Janeiro, D. F.I Sai 28.X.1950 D. A. Albuquerque L.' (2 machos, 1 fêmea, MNRJ); ' Com. I. O. Cruz\ Brasil- S. Paulo\Ilha Secal 18/ 26.II.1940' (2 macho, 1 fêmea, MNRJ); 'Com. Inst. O. Cruz\ Ilha Seca S. Paulo\ Brasil 19.26-2-40' (2 fêmeas, MNRJ)';

Material adicional examinado: Brasil. Santa Catarina: Itajaí, ix.1988, C. G. Paloschi col. (2 fêmeas, DZUP); idem, 15.ix.1988, idem (2 fêmeas, DZUP); idem, [semdia] x.1988, idem (1 fêmea, DZUP); idem, xi.1988, idem (3 machos, DZUP); idem, xii.1988, idem (2 machos, 1 fêmea, DZUP); Rio Grande do Sul: Quaraí, Estância S. Roberto, 21.xi.1985, J.R. Cure col. (1 macho, DZUP).

Distribuição geográfica: Brasil: Mato Grosso, Goiás, Minas Gerais, Rio de Janeiro, São Paulo, Paraná, Santa Catarina, Rio Grande do Sul.

Agradecimentos. Ao Conselho Nacional de Pesquisas e Desenvolvimento Científico e Tecnológico $(\mathrm{CNPq})$ pela concessão da bolsa de estudos (processo número: 133661/2004-0) para a realização do Mestrado do autor sênior (LDW); pela bolsa de produtividade em pesquisa de CJBC (processo número: 302454/2005-5). Ao projeto Taxon Line por disponibilizar o equipamento e o programa (AutoMontage) para a aquisição das fotos.

\section{REFERÊNCIAS}

Albuquerque, D. de O. 1945a. Sobre Fannia trimaculata (Stein, 1897) Malloch, 1913, (Diptera Muscidae). Boletim do Museu Nacional Rio de Janeiro (Zoologia) 34: 1-11

Albuquerque, D. de O. 1945b. Descrição do alótipo macho de Fannia petrochiae Shannon \& Del Ponte, 1926 e notas sobre a fêmea (Diptera, Muscidae). Boletim do Museu Nacional Rio de Janeiro (Zoologia) 41: 1-4.

Albuquerque, D. de O. 1946. Sobre Fannia obscurinervis (Stein, 1900) Stein, 1911 (Diptera, Muscidae). Boletim do Museu Nacional Rio de Janeiro (Zoologia) 57: 1-9.

Albuquerque, D. de O. 1953. Sobre a identidade de Fannia erythropsis (Bigot) e Fannia armata (Bigot) nec Meigen (Diptera, Muscidae) Anais da Academia Brasileira de Ciências 25: 495-498.

Albuquerque, D. de O. 1954a. Sobre duas novas espécies de Fannia R.D. do Brasil (Diptera, Muscidae). Anais da academia de Ciências 26: 317-322.

Albuquerque, D. de O. 1954b. Descrição de nova espécie do gênero Fannia e redescrição F. flavicincta (Stein, 1904) (Diptera, 
Muscidae). Revista Brasileira de Entomologia 2: 71-80.

Albuquerque, D. de O. 1954c. Descrição de três espécies novas de Fannia R-D. brasileiras, com palpos e antenas amarelos (Diptera: Muscidae).Anais da Academia Brasileira de Ciências 26: 385394.

Albuquerque, D. de O. 1956. Uma espécie nova de Fannia R.-D. (Diptera, Muscidae). Revista Brasileira de Biologia 16: 33-35.

Albuquerque, D. de O. 1957. Sobre espécies de Fannia R.-D., 1830 novas ou pouco conhecidas (Diptera, Muscidae). Boletim do Museu Nacional Rio de Janeiro (Zoologia) 172: 1-31

Albuquerque, D. de O. 1958. Sobre uma nova espécie de Fannia R.-D., 1830 (Diptera, Muscidae). Revista Brasileira de Entomologia 8: 21-24.

Albuquerque, D. de O. 1980. Descrição de uma espécie nova de Fannia Robineau-Desvoidy, 1830 (Diptera, Fanniidae), com o esternito V dourado. Dusenia 12: 21-23.

Albuquerque, D. de O.; D. Pamplona \& C. J. B. de Carvalho. 1981. Contribuição ao conhecimento dos Fannia R. D., 1830 da Região Neotropical (Diptera, Fanniidae). Arquivo do Museu Nacional Rio de Janeiro 56: 9-34.

Al Gazi, A. D. F.; M. Belo \& J. M. dos Santos. 2004. Microscopia eletrônica de varredura de duas espécies de Fannia RobineauDesvoidy (Diptera, Fanniidae). Revista Brasileira de Entomologia 48: 169-180.

Almeida, J. R. de; C. J. B. de Carvalho \& S. R. Malkowski. 1985. Dípteros sinantrópicos de Curitiba e arredores (Paraná, Brasil). II. Fanniidae e Anthomyiidae. Anais da Sociedade Entomológica do Brasil 14: 277-288.

Amendt, J.; R. Krettek \& R. Zehner. 2004. Forensic entomology. Naturwissenchaften 91: 51-65.

Araújo, P. F. de \& M. S. Couri. 1996. Duas novas espécies de Fannia Robineau-Desvoidy (Diptera, Fanniidae) do Rio de Janeiro. Brasil. Revista Brasileira de Zoologia 13: 335-341.

Brum, J. G. W.; E. E. S. Vianna; F. Gentilini. \& L. S. Pinto. 1996. Fannia punctipennis (Diptera: Fanniidae), vetor de ovos da Dermatobia hominis (Oestridae: Cuteribrinae) em Pelotas, RS. Revista Brasileira de Parasitologia Veterinária 5: 59-60.

Bruno, T. V.; J. H. Guimarães; A. M. M. dos Santos \& E. C. Tucci. 1993. Mosca sinantrópicas (Diptera) e seus predadores que se criam em esterco de aves poedeiras confinadas no Estado de São Paulo, Brasil. Revista Brasileira de Entomologia 37: 577-590.

Bruno, T. V.; J. H. Guimarães; E. C. Tucci \& A. M. M. dos Santos. 1992. Parasitóides associados a dípteros sinantrópicos de granjas de aves de postura no Estado de São Paulo, Brasil. Revista Brasileira de Parasitologia Veterinária 1: 55-59.

Campos, C. F. M. \& A. T. M. Barros. 1995. Dípteros muscóides da área urbana de Corumbá, Mato Grosso do Sul, Brasil. Revista Brasileira de Biologia 55: 351-354

Carvalho, C. J. B. de. 1991. Descrição de Fannia euchaetophora sp.n. (Diptera, Fanniidae) da Ilha de Maracá, Roraima. Revista Brasileira de Entomologia 35: 35-38.

Carvalho, C. J. B de; A. C. Pont; M. S. Couri. \& D. Pamplona. 2003. A catalogue of the Fanniidae (Diptera) of the Neotropical Region. Zootaxa 219: 1-32.

Carvalho, C. J. B de; M. O. Moura \& P. B. Ribeiro. 2002. Chave para adultos de dípteros (Muscidae, Fanniidae, Anthomyiidae) associados ao ambiente humano no Brasil. Revista Brasileira de Entomologia 46: 107-114.

Carvalho, C. J. B. de \& M. S. Couri. 1993. Descrição de Fannia rafaeli sp.n. do Amazonas, Brasil (Diptera, Fanniidae). Revista Brasileira de Entomologia 37: 559-562.

Carvalho, L. M. L.; P. I. Thyssen; A. X. Linhares \& F. A. B. Palhares. 2000. A checklist of arthropods associeted with pig carrion and human copses in southeastern Brazil. Memórias do Instituto Oswaldo Cruz 95: 135-138.

Chillcott, J. G. 1961. A revision of the Neartic species of Fanniinae (Diptera: Muscidae).Canadian Entomologist Supplement 14: $1-295$.

Couri, M. S. 1992a. Oogênese em Fannia pusio (Wiedemann) e Fannia heydenii (Wiedemann, 1830) (Diptera: Fanniidae). Revista
Brasileira de Zoologia 7: 59-67.

Couri, M. S. 1992b. Influência da dieta no desenvolvimento oogênico de Fannia pusio (Wiedemann, 1830) (Diptera, Fanniidae). Revista Brasileira de Zoologia 7: 85-88.

Couri, M. S. 2004. Two new species of Fannia Robineau-Desvoidy (Diptera, Fanniidae). Brazilian Journal of Biology 64: 767770 .

Couri, M. S. 2005a. An illustrated key to adult males of Neotropical Fannia Robineau-Desvoidy belonging to pusio sub-group (Diptera, Fanniidae). Brazilian Journal of Biology 65: 625-629.

Couri, M. S. 2005b. Fannia carvalhoi sp. nov.: a new species from Peru (Diptera, Fanniidae). Revista Brasileira de Zoologia 49: 457-458.

Couri, M. S. \& D. Pamplona. 1990. Uma nova espécie de Fannia Robineau-Desvoidy, 1830 (Diptera, Fanniidae) de Manaus (Amazonas, Brasil). Boletim do Museu Paraense Emílio Goeldi 6: $115-120$.

Couri, M. S. \& E. Winagraski. 2005. New Fannia Robineau-Desvoidy from Amazonas, Brazil and new geographical record (Diptera, Fanniidae). Revista Brasileira de Zoologia 22: 645-647.

Couri, M. S. \& P. F. de Araújo 1989. Uma nova espécie de Fannia Robineau-Desvoidy, 1830 do Brasil (Diptera, Fanniidae). Revista Brasileira de Zoologia 6: 617-620.

Crosskey, R. W. 1980. Catalogue of the Diptera of Afrotropical Region. British Museum (Natural History). London. 1467 pp.

Dominguez, M. C. 2007. A taxonomic revision of the Southern South American species of the genus Fannia Robineau-Desvoidy (Diptera: Fanniidae). Papéis Avulsos de Zoologia 47: 289-347.

Espíndola, C. B. \& M. S. Couri. 2004. Fannia flavicincta Stein (Diptera, Fanniidae): a new vector of Dermatobia hominis (Linnaeus) (Diptera, Cuterebridae). Revista Brasileira de Zoologia 21: 115116.

Gomes, P. R.; W. W. Koller; A. Gomes; C. J. B. de Carvalho \& R. Zorzatto 2002. Dípteros fanídeos vetores de ovos de Dermatobia hominis em Campo Grande, Mato Grosso do Sul. Pesquisa Vetetinária Brasileira 22: 114-118.

Guimarães, J. H. \& N. Papavero. 1999. Myiasis in man and animals in the Neotropical Region: Bibliographic database. FAPESP, São Paulo. 308 p.

Holloway, B. A. 1984. Larvae of New Zealand Fanniidae (Diptera: Calyptrata). New Zealand Journal of Zoology 11: 239-258.

Labud, V. A.; L. G. Semenas \& F. Laos. 2003. Diptera of sanitary importance associated with composting of biosolids in Argentina. Revista de Saúde Pública 37: 722-728.

Leandro, M. J. F. \& J. M. d' Almeida. 2005. Levantamento de Calliphoridae, Fanniidae, Muscidae e Sarcophagidae em um fragmento de mata na Ilha do Governador, Rio de Janeiro, Brasil. Iheringia 95: $377-381$.

Linhares, A. X. 1981. Synanthropy of Muscidae, Fanniidae and Anthomyiidae (Diptera) in the city of Campinas, São Paulo, Brazil. Revista Brasileira de Entomologia 25: 231-243.

Lomônaco, C. \& A. P. Prado. 1994. Estrutura comunitária e dinâmica populacional da fauna de dípteros e seus inimigos naturais em granjas avícolas. Anais da Sociedade Entomológica do Brasil 23: 7179.

Malloch, J. R. 1934. Muscidae. In: Diptera of Patagonia and South Chile 7: 171-346.

Marchiori, C. H. \& A. P. do Prado. 1995. Longevidade e fecundidade de Fannia pusio (Wiedemann, 1830) (Diptera: Fanniidae), em laboratório. Revista Brasileira de Biologia 55: 571-575.

Marchiori, C. H. \& A. P. do Prado. 1996a. Efeito da temperatura no desenvolvimento dos estágios imaturos de Fannia pusio (Wiedemann, 1830) (Diptera: Fanniidae), em laboratório. Revista Brasileira de Biologia 56: 93-98.

Marchiori, C. H. \& A. P. do Prado. 1996b. Padrão e horário de emergência de adultos de Fannia pusio (Wiedemann) (Diptera: Fanniidae). Anais da Sociedade Entomológica do Brasil 25: 573-576.

Marchiori, C. H. \& A. P. do Prado. 1999. Tabela de vida de Fannia pusio (Wied.) (Diptera: Fanniidae). Anais da Sociedade Entomológica do Brasil 28: 557-563. 
Marchiori, C. H.; C. G. Silva; E. R. Caldas; C. I. S.Vieira; K. G. S. Alameida; A. X. Teixeira \& A. X. Linhares. 2000. Dípteros muscóides associados com carcaça de suíno e seus parasitóides em área de pastagem e mata em Goiás. Arquivo Brasileiro de Medicina e Veterinária 52: 350-353.

Marchiori, C. H.; L. A. Pereira \& O. M. S. Filho. 2002. Primeiro relato do parasitóide Paraganapis egeria (Díaz \& Gallardo) (Hymenoptera: Figitidae) parasitando estágios de imaturos de Fannia pusio (Wiedemann) (Diptera: Fanniidae) no Brasil. Arquivos do Instituto de Biologia 69: 101-102.

Marchiori, C. H.; O. M. S. Filho; F. C. A. Fortes; R. R. Brunes; R. F. Borges; P. L. P. Gonçalves \& J. F. Laurindo. 2005. Parasitóides de Fannia pusio (Wiedemann, 1830) (Diptera: Fanniidae) coletados em Caldas Novas, Goiás, Brasil. Ciência Agrotécnica 29: 12881291.

Monteiro-Filho, E. L. de A. \& J. L. Penereiro. 1987. Estudo de decomposição e sucessão sobre uma carcaça animal numa área de Estado de São Paulo, Brasil. Revista Brasileira de Biologia 47: $289-295$.

Moura, M. O.; C. J. B. de Carvalho \& E. L. A. Monteiro-Filho. 1997. A preliminary analysis of insects of medical-legal importance in Curitiba, State of Paraná. Memórias do Instituto Oswaldo Cruz 92: 269-274.

Moura, M. O.; C. J. B. de Carvalho \& E. L. A. Monteiro-Filho. 1998. Carrion attendent arthropods in South Brazil. Ciência e Cultura 50: $377-381$.

Mullens, B. A.; C. E. Szijj. \& N. C. Hinkle. 2002. Oviposition and development of Fannia spp. (Diptera: Muscidae) on poultry manure of low moisture levels. Environmental Entomology 31: 587593.

Oliveira, G. P. de. 1986. Distribuição sazonal de dípterors muscóides sinantrópicos, simbovinos e foréticos de Dermatobia hominis L. Jr., em São Carlos, Estado de São Paulo. I. Estábulo. Arquivos de Biologia e Tecnologia 29: 311-325.

Perotti, A. 1998. Moscas sinantrópicas (Diptera: Muscidae y Fanniidae) associadas a producciones avícolas del centro-sudeste bonaerense. Natura neotropicalis 29: 145-154.

Pinto L. S. \& J. G. W. Brum. 1998. Aspectos biológicos da fase adulta de Fannia pusio (Wiedemann, 1830) (Diptera: Fanniidae), em condições de laboratório. Arquivos de Biologia e Tecnologia 65: $135-137$.

Pont, A. C. 1977a. Family Muscidae, p. 451-523. In: Delfinado, M. D. \& D. E. Hardy, A Catalogue of the Diptera of the Oriental Region. Vol. III. Suborder Cyclorrhapha (excluding Division Aschiza). The University Press of Hawaii, Honolulu, 834 p.

Pont, A. C. 1977b. A revision of Australian Fanniidae (Diptera: Calyptrata). Australian Journal of Zoology. Supl. 51: 1-60.

Pont, A. C. 1989. Family Fanniidae, p. 700-701. In: Evenhuis, N. L. (Ed). Catalog of the Diptera of Australasian and Oceanin regions. Bishop Museum Special Publication. Bishop Museum Press, Honolulu \& E. J. Brill, Leinden. 804 p.

Pont, A. C. \& C. J. B. de Carvalho. 1994. Neotropical Fanniidae (Diptera): A key to the Fannia anthracina-group. Entomologist's Monthky Magazine 130: 229-237.

Queiroz, S. M. P. de \& C. J. B. de Carvalho. 1987. Chave pictórica de larvas de $3^{\circ}$ ínstar de Diptera (Calliphoridae, Muscidae e Fanniidae) em vazadouros de resíduos sólidos domésticos em em curitiba, Paraná. Anais da Sociedade Entomológica do Brasil 16: 265288.

Ribeiro, P. B.; C. M. B. Oliveira; P. R. P. Costa \& J. G. W. Brum. 1985. Foréticos de Dermatobia hominis (L. Jr. 1781) (Diptera: Cuterebridae) no Rio Grande do Sul. Arquivo Brasileiro de Medicina Veterinária e Zootecnia 37: 507-509.

Roskosný, R.; F. Gregor \& A. C. Pont. 1997. The European Fanniidae (Diptera). Acta Scientiarum Bohemicae Brno 31: 1-80.

Seago, J. M. 1954. The pusiogroup of the genus Fannia Robineau Desvoidy, With descriptions of new Species (Diptera: Muscidae). Americam Mueum Novitates 1699: 1-13.

Stein, P. 1911. Die von Schnuse in Südamerika gefangenem Anthomyiden. Archiv für Naturgeschichte 77: 1-189.

Stone, A.; W. W. Sabrosky; R. H. Foote. \& J. R. Coulson. 1965. A catalog of the Diptera of America North of Mexico. Agricultural Research Service. United States Departament of Agriculture. Washington, D.C. 1696 p.

Wendt, L. D. \& C. J. B. de Carvalho. 2007. Taxonomia de Fanniidae (Diptera) do sul do Brasil - I: nova espécie e chave de identificação de Euryomma Stein. Revista Brasileira de Entomologia 51 : 197-204.

Recebido em 04/07/2008; aceito em 10/12/2008 